DOE/ETA- -0436(90)

DE91 001973

\title{
World Nuclear Fuel Cycle Requirements 1990
}

\section{Energy Information Administration}

Office of Coal, Nuclear, Electric and Alternate Fuels

U.S. Department of Energy

Washingt' $n$, DC 20585

This report was prepared by the Energy Information Administration, the independent statistical and analytical agency within the Department of Energy. The information contained herein should not be construed as advocating or reflecting any policy position of the Department of Energy or of any other organization. 


\section{Contacts}

This report was prepared in the Nuclear and Alternate Fuels Division of the Office of Coal, Nuclear, Electric and Alternate Fuels. Questions regarding the contents of the report should be addressed to Howard Walton, Director of the Nuclear and Alternate Fuels Division (202/254-5500), Betsy $\mathrm{O}^{\prime}$ Brien, Chief of the Data Analysis and Forecasting Branch (202/254-5506), William Liggett, the project manager (202/254-5544), or to Laurence Sanders, project analyst $(202 / 254-5545)$. 


\section{Preface}

This analysis report presents the projected requirements for uranium concentrate and uranium enrichment services to fuel the nuclear power plants expected to be operating under three nuclear supply scenarios. Two of these scenarios, the Lower Reference and Upper Reference cases, apply to the United States, Canada, Europe, the Far East, and other countries with free market economies (FME countries). A No New Orders scenario is piesented only for the United States. These nuclear supply scenarios are described in Commercial Nuclear Powerer 1990: Prospects for the United States and the World (DOE/EIA-0438(90)).

This report contains an analysis of the sensitivities of the nuclear fuel cycle projections to different levels and types of projected nuclear capacity, different enrichment tails assays, higher and lower capacity firtors, changes in nuclear fuel burnup levels, and otixer exogenous assumptions. The projections for the United States generally extend through the year 2020, and the FME projections, which include the United States, are provided through 2010.

The report also presents annual projections of spent nuclear fuel discharges and inventories of spent fuel. Appendix D includes domestic spent fuel projections through the year 2030 for the Lower and Jpper Reference cases and through 2040, the last year in which spent fuel is discharged, for the No New Orders case. These disaggregated projections are provided at the request of the Department of Energy's Office of Civilian Radioactive Waste Managenient.

This report is intended for the Congress of the United States, Federal and State agencies, and the nuclear industry. It will be of particular interest to analysts involved in long-term planning for the disposition of radioactive waste generated from the nuclear fuel cycle. The domestic and foreign uranium requirements presented in this report are used as input assumptions in developing the annual report, Domestic Uranium Mining and Milling Industry: Viability Assessment (DOE/EIA-0477).

The International Nuclear Model (INM), used for calculating the projected nuclear fuel cycle requirements in this report, is documented in International Nuclear Model, Volumes I, II, and III, prepared by Systems Sciences, Inc. (Bethesda, Maryland). The documentation and a computer tape containing the programs, data input files, output files for this report, and instructions for use of the model that will allow users to reproduce the results of the study, are available from the National Energy Information Center, Room 1F-048, Forrestal Building, Washington, DC 20585 (202/586-8800). 


\section{Contents}

Executive Summary $\ldots \ldots \ldots \ldots \ldots \ldots \ldots \ldots \ldots \ldots \ldots \ldots \ldots \ldots \ldots \ldots \ldots \ldots$

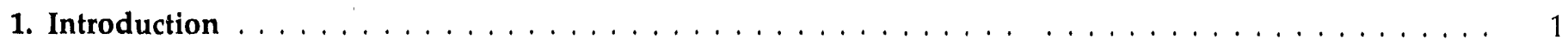

2. Projections of U.S. Nuclear Fuel Cycle Requirements $\ldots \ldots \ldots \ldots \ldots \ldots \ldots \ldots$

Introduction $\ldots \ldots \ldots \ldots \ldots \ldots \ldots \ldots \ldots \ldots \ldots \ldots \ldots \ldots$

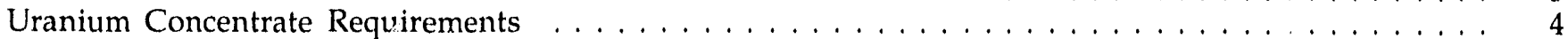

U.S. Uranium Enrichment Service Requirements $\ldots \ldots \ldots \ldots \ldots \ldots \ldots \ldots$

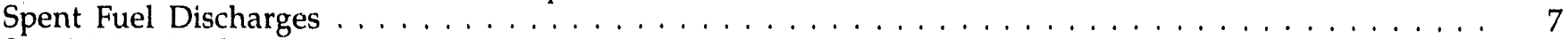

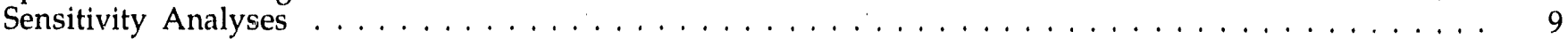

3. Projections of Nuclear Fuel Cycle Requirements for the Free Market Economies . . . . . . . . . . 17

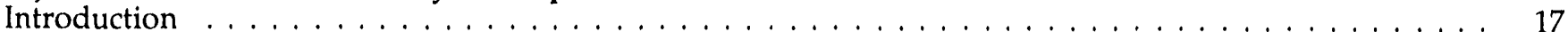

Uranium Concentrate Requirements $\ldots \ldots \ldots \ldots \ldots \ldots \ldots$

Uranium Enrichment Service Requirements $\ldots \ldots \ldots \ldots \ldots \ldots \ldots \ldots \ldots$

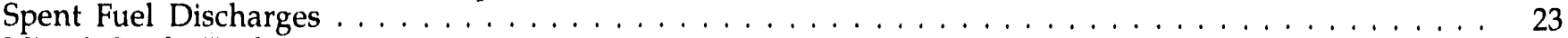

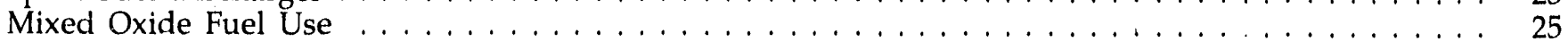

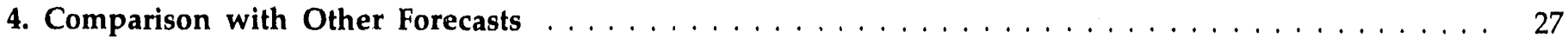

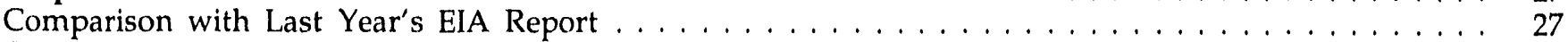

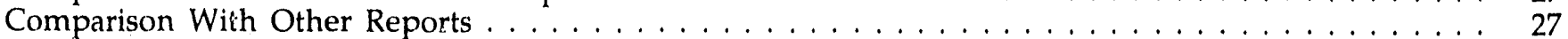

Appendices

A. Nuclear Power Technology and the Nuclear Fuel Cycle $\ldots \ldots \ldots \ldots \ldots \ldots \ldots$

B. Methodology and Assumed Fuel Cycle Plans for Increased Fuel Burnup . . . . . . . . . . . . . 41

C. Nuclear Fuel Cycle Facilities That Prepare Fuel for Nuclear Power Plants . . . . . . . . . . . . . . . 49

D. Projections of U.S. Spent Fuel Discharges, $1990-2040 \ldots \ldots \ldots \ldots \ldots \ldots \ldots$

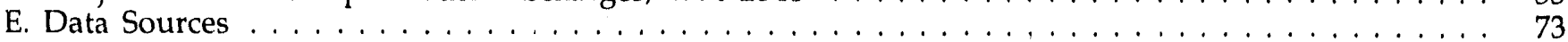

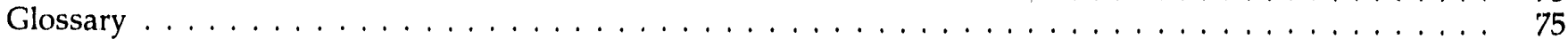




\section{Tables}

ES1. Projections of U.S. Nuclear Fuel Cycle Requirements, 1990)-1995, 2001-2005, and 2016-2020 _... . xi

ES2. Projections of Nuclear Fuel Cycle Requirements for the Free Market Econon:ies,

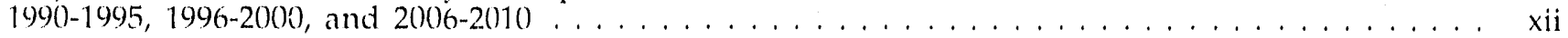

1. U.S. Operable Nuclear Capacity at the End of the Year, 1989 and Projections for 199()-2020 . . . . 3

2. Projected Average Annual Natural Uranium Requirements for U.S. Nuclear Power Plants, 199()$-2(20)$

3. Projected Cumulative Natural Uranium Requirements for U.S. Nuclear Power Plints, 1990-2020...

4. Projected Average Annual Uranium Enrichment Service Requirements for U.S. Nuclear

Power Plants, 1990-2020

5. Avera Annual Spent Fuel . . . . . . . . . . . . . . . . . . . . . . . . . . . . .

5. Avernge Annual Spent Fuel Discharges from U.S. Nuclear Power Plants, 1990-2020 . . . . . . . . . .

6. Cumulative Spent Fuel Discharges From U.S. Nuclear Power Plants: Total From $1957 \ldots \ldots \ldots$

7. Sensitivity of Lower-Reference-Case Projections of U.S. Nuclear Fuel Cycle Requirements

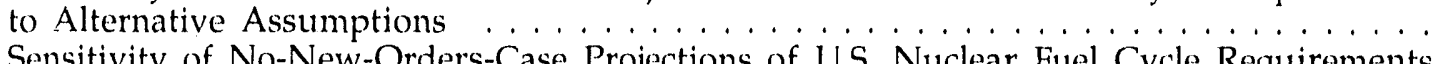

8. Sensitivity of No-New-Orders-Case Projections of U.S. Nuclear Fuel Cycle Requirements

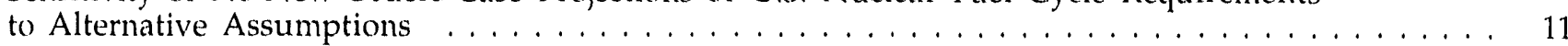

9. Projected Capacity of Foreign Nuclear Power Plants in the Free Market Economies, 1990-2010 . . . 17

10. Projected Average Annual Uranium Requirements for Nuclear Power Plants in the Free Market Economies, 1990-2010

11. Projected Cumulative Uranium Requirements for Nuclear Power Plants in the

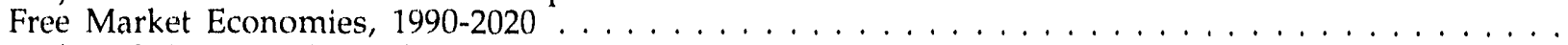

12. Projected Average Annual Uranium Enrichment Service Requirements for Nuclear Power Plants

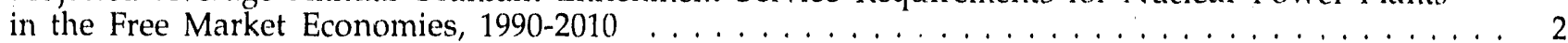

13. Projected Nominal Capacity of World Uranium Enrichment Hacilities at the End of the Year . . . . 23

14. Projected Average Annual Discharges of Spent Fuel from Nuclear Power Plants in the Free Market Economies, 1990-2010

15. Projected Cumulative Discharges of Spent Fuel from Nuclear Power Plants in the Free Market Economies, 1990-2010

16. Sensitivity of Lower-Reference-Case Projections of European Nuclear Fuel Cycle Requirements to Mixed-Oxide Fuel Use Assumption, $1990-2010 \ldots \ldots \ldots \ldots \ldots \ldots \ldots \ldots$

17. Comparison of Selected Forecasts of U.S. Fuel Cycle Requirements . . . . . . . . . . . . . . . . . 28

18. Comparison of Selected Forecasts of Fuel Cycle Requirements for the Free Market Economies . . . . 29

19. Comparison of Actual U.S. Spent Fuel Discharges With Projections From This Annual Report . . . 30

B1. Results of the Regression Analysis of the Enrichment Assay Equations . . . . . . . . . . . . . . . . 44

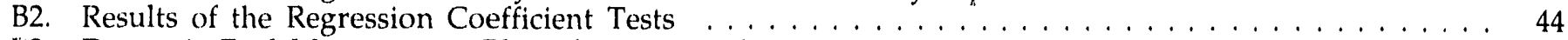

B3. Domestic Fuel Management Plans for Extended Burnup Scenarios $\ldots \ldots \ldots \ldots \ldots \ldots$

B4. Foreign Fuel Management Plans for Extended Burnup Scenarios . . . . . . . . . . . . . . . . . . 46

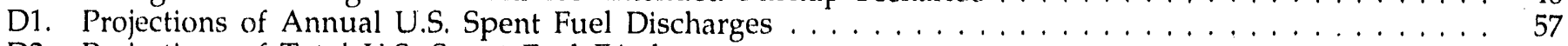

D2. Projections of Total U.S. Spent Fuel $[$ ischarges $\ldots \ldots \ldots \ldots \ldots \ldots \ldots \ldots$

D3. Projected Average Burnup uí Spent Fuel Discharged by U.S. Nuclear Power Plants for Equilibrium Cycles

D4. Projected Average Burnup of Spent Fuel Discharged by U.S. Nuclear Power Plants for All Cycles . . . . . . . . . . . . . . . . . . . . . . . . . . . .

D5. Projected Spent Fuel Discharges by U.S. Reactors in the No New Orders Case, 1990-2000 . . . . . .

D6. Projected Spent Fuel Discharges by U.S. Reactors in the No New Orders Case, 2001-2010 . . . . . .

D7. Projected Spent Fuel Discharges by U.S. Reactors in the No New Orders Case, 2011-2020 . . . . . .

D8. Projected Spent Fuel Discharges by U.S. Reactors in the No New Orders Case, 2021-2030 . . . . . .

D9. Projected Spent Fuel Discharges by U.S. Reactors in the No New Orders Case, 2031-2040 


\section{Figures}

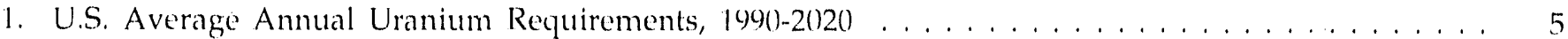

2. U.S. Total Uranium Requirements, 1990$)-2(20) \ldots \ldots \ldots \ldots \ldots \ldots \ldots \ldots \ldots$

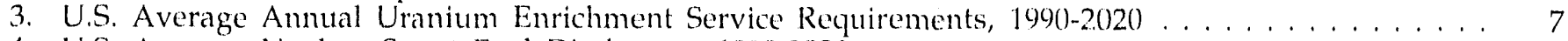

4. U.S. Average Nuclear Spent Fuel Discharges, 1990)-2020 . . . . . . . . . . . . . . . . . . . . . . \&

5. U.S. Total Nuclear Spent Fuel Discharges, 1970-2020 . . . . . . . . . . . . . . . . . . . . . . . . . . 9

6. Average Equilibrium-Cycle Discharge Burnup for U.S. Boiling-Water Reactors, 1972-2010 . . . . . 13

7. Average Equilibrium-Cycle Discharge Burnup for U.S. Pressurized-Water Reactors, 1972-2010 _ . . 14

8. Average Annual Uranium Requirements for the Free Market Economies, 1990-2010 . . . . . . . . . . 20

9. Cumulative Uranium Requirements for the Free Market Economies, 1990-2010 . . . . . . . . . . . . 21

10. Average Annual Uranium Enrichment Service Requirements for the Free Market Economies,

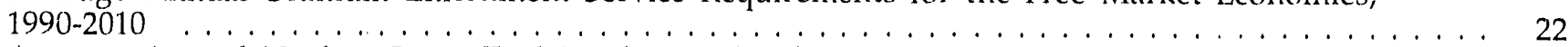

11. Average Annual Nuclear Spent Fuel Discharges for the Free Market Economies, 1990-2010 . . . . . 24

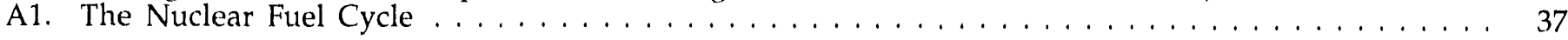




\section{Executive Summary}

The nuclear fuel cycle consists of mining and milling uranium ore, processing the uranium into a form suitable for generating electricity, "burning" the fuel in nuclear reactors, and managing the resulting spent nuclear fuel. This report presents projections of domestic and foreign requirements for natural uranium and enrichment services as well as projections of discharges of spent nuclear fuel. These fuel cycle requirements are based on the forecasts of future commercial nuclear power capacity and generation published in a recent Energy Information Administration (EIA) report.'

This report also contains projections of the amount of spent fuel discharged at the end of each fuel cycle for each nuclear generating unit in the United States.

\section{Assumptions}

\section{Domestic}

Three nuclear supply reference scenarios for the United States (No New Orders, Lower Reference, and Upper Reference) are included in this report. These scenarios reflect different assumptions about schedules for construction of nuclear power plants, cancellations, and new orders for reactors. In the Lower Reference and Upper Reference cases, the United States is projected to have 116 and 146 net gigawatts-electric (GWe) of operable nuclear power capacity, respectively, in the year 2020. In the No New Orders case, it is projected that there will be only 54 net GWe capacity that year because reactors are assumed to be retired 40 years after the issuance of their operating license, and no nuclear capacity replacement is assumed.

In addition to studying the effects of three scenarios of projected nuclear power capacity, seven sensitivity cases based on the nuclear capacities of the No New Orde:ss and Lower Reference cases, are examined to determine the potential effects of varied assumptions on projected fuel cycle requirements. The basic assumptions used for the projections are as follows:

- Capacity factors in the equilibrium cycle range from 62 percent in 1990 to a high of 70 percent in 2020 .
- Enrichment tails assay (the concentration of U235 in the waste stream from the enrichment process) is at 0.30 percent in 1990 through 2000 , then drops to 0.25 percent by 2005 and remains constant through 2020. Year-by-year tails assay assumptions are displayed in the main body of the report.

- Design burnup, a measure of the amount of energy obtained from the fuel in a reactor, goes from about 34,06' megawattdays thermal per metric ton of initial heavy metal (MWDT/ MTIHM) in 1990 te 42,000 MWDT/MTIHM in 2010 and beyond for LWR's, and from about 39,000 MWDT/MTIHM in 1990 to 48,000 MWDT/MTIHM in 2005 and beyond for PWR's. Appendix B shows specific design burnup assumptions bv year and other important factors about the fuel plans.

- Plants are retired after 40 year of operation.

The seven domestic sensitivity cases are as follow's:

1. Capacity factors in the equilibrium cycle remain constant at 62 percent from 1990 through 2020.

2. Capacity factors in the equilibrium cycle increase to 69 percent by 1998 and 74.0 percent by 2020 .

3. The enrichment tails assay is 0.2 percent in each year of the projection.

4. The enrichment tails assay is 0.3 percent in each year of the projection.

5. No increase in design burnup occurs beyond 1990 levels.

6. The design burnup increases at an accelerated pace and increases to $47,000 \mathrm{MWDT} / \mathrm{MTIHM}$ for boiling-water reactors in 2010 and 52,000 MWDT/MTIHM for pressurized-water reactors in 2005 .

7. Plant lives are extended to 60 years for 70 percent of installed capacily. 


\section{Free Market Economies}

Two nuclear supply scenarios (Lower Reference and Upper Reference) are given for countries with free market economies (FME countries). For the FME countries, excluding the United States, nuclear power capacity is projected to range from 216 to 253 CWWe in the year 2010 for the Lower and Upper Reference case, respectively. By the end of 1989, 245 nuclear reactors were operable in the FME countries, representing 176 net GWe of nuclear capacity, and 70 units were in the construction pipeline totaling about 65 net GWe. The basic assumptions used for the projections are as follows:

- Capacity factors range from 67 percent to 71 percent over the projection period. This is an average for all FME countries (including the Lnited States).

- Enrichment tails assay for light-water reactors is kept constant at 0.25 percent over the projection period (excluding the United States, which was ncted above).

- Cesign burnup goes from about 32,000 MWDT/ MTIHP, in 1990 to $44,000 \mathrm{MWDT} / \mathrm{MTIHM}$ in 2000 and beyond for boiling-water reactors, and from about 34,000 MWDT/MTIHM in 1990 to 49,000 MWDT/MTIHM in 2000 and beyond for pressurized-water reactors. Appendix B shows specific dasign burnup assumptions by year ald other important factors about the fuel plans.

- Plants are retired after 30 years of operation.

\section{Frojections}

\section{Domestic}

In the Lower Reference case for the United States, the average annual domestic requirements for uranium concentrate are projected to increase from an average of 38.9 million pounds $\mathrm{U}_{3} \mathrm{O}_{k}$ in 1990 through 1995 to 46.8 million pounds by the years 2016 through 2020 (Table ES1). The required enrichment services are projectec to increase froin an annual average of 8.1 million separative work units in 1990 through 1995 to 12.6 million separative work units for the years 2016 through 2020. The total amount of spent fuel projected to be in inventory at the end of 1995 is 31.4 thousand metric tons of initial heavy metal and is expected to grow to 80.2 thousand metric tons by 2020. At the end of 1989, there were 19.6 thousand metric tons in inventory which utilities do not currently plan to irradiate further (Table 6).
Uncertainty aboul future nuclear capacity produces the largest variation in projected fucl cycle requirements and spent fuel discharges. fior example, in the No New Orders case the total spent fuel discharged through 2020 is 6.7 pereent less than in the Lewer Reference case, and average amnual uranium concentrate, and enrichment service reguirements in the years 2016 through 2020 are 59.3 percent and 56.4 percent less, respectively.

Changes in capacity factors affect both the amount of electricity generated by nuclear units and the amount of fuel consumed. In general, lower capacity factors restilt in lower aggregate requirements for uranium concentrate and enrichment services and lower spent fuel discharges, while higher capacity factors have the opposite effect. However, changes in capacity factor can also change the date that a nuclear unit refuels if it operates until the planned burnup of the fuel is achieved.

The choice of a tails assay affects natural uranium and enrichment requirements. For a given enriched uranium product, the natural uranium required as feed for the enrichment process decreases and the enrichment services increase when a lower tails assay is selected. The opposite occurs for higher tails assays. The U.S. Department of Energy's Utility Services Enrichment Contract allows customers to select a tails assay between 0.2 and 0.3 percent U-235. Because minimum reactor fuel cost is a criterion for selecting a lails assay, the choice depends on the prices of natural uranium and enrichment, as well as on the quantities of each that would be required. In the years 2016 through 2020, a tails assay of 0.3 percent rather than the base case assumption of 0.25 percent increases the average annual requirements for natural uranium by $10 . t$ percent and decreases the average annual enrichment service requirements by approximately 9.6 percent.

Recently, electric utilities have been able to increase the burnup for their reactors by increasing the concentration of U-235 in the enriched uranium fuel and changing the design specifications of the fuel rods. At higher fuel burnups, the length of the operating cycle is increased and/or a smaller fraction of the core is replaced at each fuel loading. For this report, it is assumed that a nuciear unit will operate until the planned burnup of the fuel is achieved. As shown in Table ES1, without this continued increase in future burnup levels, the total spent fuel discharged will be 8.0 percent higher than the Lower Reference case in 2020 and the average annual natural uranium and es.richment requirements in 2016 through 202') will be 1.5 percent higher and 3.4 percent lower, respectively, than the Lower Reference 
case. If burnup levels rise above the level achieved in the Lower Reference case, total spent fucl discharges will be 0.7 pereent lower in 2020 .

\section{Free Market Economies}

Average annual uranium requirements for the FiME (including the United States) nations are projected to be 16 percent higher in the years 2006 through 2010 than for the years 1990 through 1995 in the l.ower Reference case (Table ES2). The United States accounts for about 35 pereent of the annual uranium reguirements in the years 1090 through 1995. Average annual uranium entrichnent service reguirements are projected to be 22 pereent higher in the years 2006 throwgh 2010 than for the years 1900$)$ through 1995. The United States accounts for about 30) percent of the annual enrichment services in the years 1990) through 1995. Average annual spent fuel discharges are projected to remain relatively stable from 1990 through 2010 averaging near 9.8 thousand metric tons per year.

Table ES1. Projections of U.S. Nuclear Fuel Cycle Requirements, 1990-1995, 2001-2005, and 2016-2020

\begin{tabular}{|c|c|c|c|c|c|c|c|c|c|}
\hline \multirow[b]{2}{*}{ Assumptions } & \multicolumn{3}{|c|}{$\begin{array}{c}\text { Average Annual } \\
\text { Natural Uranium } \\
\text { Requirements } \\
\text { (million pounds } \cup_{3} O_{8} \text { equivalent) }\end{array}$} & \multicolumn{3}{|c|}{$\begin{array}{c}\text { Average Annual } \\
\text { Uranium Enrichment Service } \\
\text { Requirements } \\
\text { (million separative work units) }\end{array}$} & \multicolumn{3}{|c|}{$\begin{array}{l}\text { Total Spent Fuel } \\
\text { Discharges } \\
\text { (tholssand metric tons } \\
\text { of initial heavy metal) }\end{array}$} \\
\hline & 1990-1995 & $2001-2005$ & $2016-2020$ & 1990-1995 & $2001-2005$ & $2016-2020$ & 1995 & 2005 & 2020 \\
\hline \multicolumn{10}{|l|}{ Lower-Reference-Case } \\
\hline & & ercent Diffe & rences from & wer Referen & nce Case Du & e to Variatio & $\sin A s$ & imptions & \\
\hline $\begin{array}{l}\text { Nuclear Growth } \\
\text { No New Orders . . . . . } \\
\text { Upper Reference Case }\end{array}$ & $\begin{array}{l}0.0 \\
0.0\end{array}$ & $\begin{array}{r}-2.2 \\
2.1\end{array}$ & $\begin{array}{r}-59.3 \\
27.1\end{array}$ & $\begin{array}{l}0.0 \\
0.0\end{array}$ & $\begin{array}{r}-2.0 \\
2.1\end{array}$ & $\begin{array}{r}-56.4 \\
25.7\end{array}$ & $\begin{array}{l}0.0 \\
0.0\end{array}$ & $\begin{array}{l}0.0 \\
0.0\end{array}$ & $\begin{array}{r}-6.7 \\
5.2\end{array}$ \\
\hline $\begin{array}{l}\text { With Lower } \\
\text { Capacity Factors }\end{array}$ & -1.7 & -5.1 & -6.1 & -2.3 & -2.3 & -7.3 & -0.6 & -2.2 & -3.4 \\
\hline $\begin{array}{l}\text { With Higher } \\
\text { Capacity Factors }\end{array}$ & 4.5 & 9.7 & 7.0 & 5.4 & 10.1 & 7.0 & 1.0 & 4.0 & 4.6 \\
\hline With Lower Tails Assay & -17.1 & -11.6 & -8.5 & 24.8 & 16.8 & 12.3 & 0.0 & 0.0 & 0.0 \\
\hline With Higher Tails Assay & .0 .0 & 6.8 & 10.6 & 0.0 & -5.9 & -9.6 & 0.0 & 0.0 & 0.0 \\
\hline $\begin{array}{l}\text { With Less Increase } \\
\text { in Fuel Burnup . . . . }\end{array}$ & -0.3 & 3.5 & 1.5 & -0.4 & 0.0 & -3.4 & 0.0 & 3.6 & $\cdots n$ \\
\hline With Higher Fuel Burnup & 1.3 & 0.2 & 7.9 & 1.4 & 4.8 & 6.8 & 0.0 & -0.8 & -0.7 \\
\hline With Extended Plant Lives & 0.0 & 0.2 & 25.1 & 0.0 & 0.3 & 23.8 & 0.0 & 0.0 & 1.0 \\
\hline
\end{tabular}

Source: Projected fuel cycle requirements calculated usirig the International Nuclear Model, based on capacity projections from Energy Information Administration, Commercial Nuclear Power 1990: Prospects for the United States and the World, DOE/EIA-0438(90) (Washington, DC, September 1990). 
Table ES2. Projections of Nuclear Fuel Cycle Requirements for the Free Market Economies, 1990-1995, 1996-2000, and 2006-2010

\begin{tabular}{|c|c|c|c|c|}
\hline \multirow{2}{*}{\multicolumn{2}{|c|}{ Years }} & \multicolumn{3}{|c|}{ Lower-Reference-Case Values } \\
\hline & & $\begin{array}{l}\text { Average Annual } \\
\text { Natural Uranium } \\
\text { Requirements } \\
\text { (million pounds } \\
\mathrm{U}_{3} \mathrm{O}_{3} \text { equivalent) }\end{array}$ & $\begin{array}{c}\text { Average Annual } \\
\text { Uranium Enrichment Service } \\
\text { Reculirements } \\
\text { (milllon separative } \\
\text { work units) }\end{array}$ & $\begin{array}{l}\text { Average Annual } \\
\text { Spent Fuel Discharges } \\
\text { (thousand metric tons } \\
\text { of Ihitial heavy metal) }\end{array}$ \\
\hline $1990-1995$ & 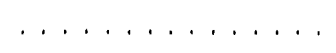 & 110.3 & 27.2 & 10.1 \\
\hline $1996-2000$ & $\ldots \ldots \ldots \ldots \ldots$ & 114.0 & 27.6 & 9.1 \\
\hline $2006-2010$ & $\cdots$ & 126.2 & 33.3 & 10.2 \\
\hline
\end{tabular}

Source: Projected fuel cycle requirements calculated using the International Nuclear Model, based on capacity projections from Energy Information Administration, Commercial Nuclear Power 1990: Prospects for the United States and the World, DOE/EIA-0438(90) (Washington, DC, September 1900). 


\section{Introduction}

This report presents historical data and projections of the nuclear fuel cycle requirements for reactors in the United States and other countries with free market economies (FME countries). The projections in the body of the report are provided for the United States through 2(1)20 and for the other FME countries through 2010. Appendix D contains projections of spent fuel discharges for the United States through 2040 in the No New Orders case and through 2030) in the other cases. A recent EIA report provides the basis for the underlying nuclear power capacity projections."

This report deals with three elements of the nuclear fuel cycle: (1) requirements for $\mathrm{U}_{3} \mathrm{O}_{4},(2)$ requirements for enrichment services, and (3) discharges of spent fuel. "Requirements" refer to the quantities needed for initial fueling or refueling of reactors and not to demand in the marketplace or to actual production. For example, the requirements for $U_{4} \mathrm{O}_{8}$ may be met by scheduled contract deliveries from domesti. or foreign producers, purchases on the spot market, or use of inventories held by utilities. Likewise, the requirements for enrichment services may be satisfied by contracts with DOE or with foreign enrichers, and also from inventories of enriched uraniin, or secondary market transactions. Information on uranium reserves, production, and market transactions can be found in the Encrgy Information Administration report, Lronium Industry Anmual 1990) (DOE/EIA-() $478(9()))$.

The projections in this report serve various purposes. I'rojections of discharges of spent fuel in the United States for the No New Orders case through the year 2(1)40, the last year in which fuel is discharged, and through 2030 for the other cases (Appendix D), are provided at the request of DOE's Office of Civilian Radioactive Waste Management, to estimate the longterm need for waste repositories. Projections of domestic and foreign requirements for uranium and enrichment services are used for the viability assessment of the domestic uranium mining and milling industry and to evaluate potential markets for enrichment services.

This report consists of four chapters. Chapter 2, "Projections of Domestic Nuclear Fucl Cycle Requirements," discusses the assumptions and results for the United States; Chapter 3, "Projections of FME Nuclear Fuel Cycle Requirements," does the same for the foreign sector. Chapter 4 contains a comparison of the projections in this report with projections by private companies. Throughout the report, comparisons are made between projections for two different time ranges for each nuclear supply scenario. Usually, comparisons are selected to show the large'st differences, in order to emplasize the impacts of the different scenarios on fuel requirements.

1

The appendices contain a brief discussion of the nuclear fuel cycle and the major components of the cycle (Appendix A); the methodology used in developing the projections contained in this report and the fuel management plans that were used (Appendix B); a list of conversion, enrichment, and fabrication facilities in the world (Appendix ()); and tables of the aggregated annual and cumulative domestic spent fuel projections and projections of spent fuel discharges at the end of each fuel cycle for each nuclear generating unit (Appendix D). 


\section{Projections of U.S. Nuclear Fuel Cycle Requirements}

\section{Introduction}

This chapter presents projections of uranium concentrate $\left(\mathrm{U}_{3} \mathrm{O}_{4}\right)$ requirements, enrichment service requirements, and spent nuel discharges based on the three domestir nuclear supply scenarios-No New Orders, Lower Reference, and Upper Reference. The three nuclear supply scenarios differ primarily in the dates in which reactors currently in the construction pipeline come online, the number of assumed newly ordered units, and the timing of their initial operation. Sensitivity cases to the basic assumptions underlying the projections using the No New Orders and Lower Reference are also examined. The basic assumptions used for the projections are as follows:

- Capacity factors in the equilibrium cycle range from 62 percent in 1990 to a high of 70 percent in 2020.

- Enrichment tails assay is at 0.30 percent in 1990 through 2000 , and then dropping to 0.25 percent by 2005 and remaining constant through 2020 . Year-by-year tails assay assumptions are displayed later in the chapter.

- Design burnup goes from about 34,000 megawattdays thermal per metric ton of initial heavy metal (MWDT / MTIHM) in 1990 to 42,000 MWDT/MTIHM in 2010 and beyr ad for BWR's, and from about 39,000 MWDT/MTIHM in 1990 to $48,000 \mathrm{MWDT} / \mathrm{MTIHM}$ in 2005 and beyond for PWR's. Appendix B shows specific design burnup assumptions by year and other important factors about the fuel plans.

- Plants are retired after 40 years of operation.

Fuel requirements and spent fuel discharges are presented as 5-year averages to indicate general trends for comparison across cases. This helps to smooth out the variation in annual projections. Variation occurs because, as new plants come on line, the first fuel loading uses 3 to 4 times the quantity of fuel used for subsequent reloads. Also contributing is the fact that most reactors are not refueled annually, so that large variations in requirements occur when a significant number of reactors skip a year.
Installed nuclear capacity at year end 1989 was 97.9 GWe with 110 operable nuclear reactors, and the overall capacity factor during the year was 62.3 percent utilization. As of December 31, 1989, there were 11 nuclear units with a total capacity of 13.1 GWe in the "construction pipeline." "Of these, 1 unit had loaded fuel and was undergoing lowpower testing. The remaining 10 had received construction permits, although construction of 6 units has been indefinitely deferred. ${ }^{3}$ The amount of spent fuel that was discharged from domestic nuclear reactors in 1989 was 2.0 thousand metric tons, bringing the total spent fuel inventory, as of the end of 1989 , to 19.6 thousand metric tons of initial heavy metal.

Table 1 summarizes the projections of domestic nuclear capacity and electricity generation for three

\section{Table 1. U.S. Operable Nuclear Capacity at the End of the Year, 1989 and Projections for 1990-2020}

\begin{tabular}{|c|c|c|c|c|c|}
\hline & \multirow{2}{*}{\multicolumn{2}{|c|}{ Year }} & \multicolumn{3}{|c|}{ Capacity (Net GWe) } \\
\hline & & & $\begin{array}{c}\text { No New } \\
\text { Orders } \\
\text { Case }\end{array}$ & $\begin{array}{c}\text { Lower } \\
\text { Reference } \\
\text { Case }\end{array}$ & $\begin{array}{c}\text { Upper } \\
\text { Reference } \\
\text { Case }\end{array}$ \\
\hline $\begin{array}{l}1989^{a} \\
1990 \\
1995 \\
2000 \\
2005 \\
2010 \\
2015 \\
2020\end{array}$ & 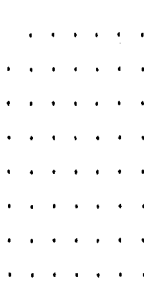 & 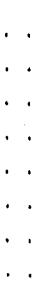 & $\begin{array}{r}98 \\
99 \\
103 \\
104 \\
104 \\
100 \\
69 \\
54\end{array}$ & $\begin{array}{r}98 \\
99 \\
103 \\
104 \\
105 \\
103 \\
103 \\
116\end{array}$ & $\begin{array}{r}98 \\
99 \\
103 \\
104 \\
105 \\
122 \\
124 \\
146\end{array}$ \\
\hline
\end{tabular}

Actual data

Note: Capacity values are based on net summer capability.

Source: Energy Information Administration, Commercial Nuclear Power 1990: Prospects for the United States and the World, DOE/EIA-0438(90) (Washington, DC, September 1990). 
nuclear supply scenarios-No New Orders, Lower Reference, and Upper Reference-from 1990 through 2020.

Projected capacity through the year 2000 reaches 104 net (iWe for all three scenarios. Under the Lower and Upper Reference cases, capacity increases to 105 net GWe by the year 2005. By the year 2020, nuclear capacity of the United States is projected to reach 136 net GWe in the Lower Reference case and 146 GWe in the Upper Reference Case. In the No New Orders case, there is projected to be only 54 net GWe of operating nuclear capacity in the year 202!) due to retirement of existing units $\mathrm{with}^{\mathrm{t} ! \mathrm{n}}$ no replacement.

It is important to note that uranium concentrate requirements and enrichment service requirements follow the trends in projected operable capacity. That is, for example, an increase in operable capacity will generally imply a corresponding $:$ icrease in uranium concentrate and enrichment services. As the reader ran observe in the sections that follow, the trends in uranium and enrichment services requirements are similar to the trends in operable capacity for each scenario shown in Table 1. There are other key fuctors, however, that affect these requirements. For example, the assay leve!s used for the enriched uranium to achieve higher fuel burnups and the tails assay used when enriching the uranium affect both the requirements for uranium concentrate and enrichment services. The relationship of the errichment and tails assays to uranium and enrichment services is discussed in more detail in the scction on sensitivity analysis.

\section{Uranium Concentrate Requirements}

In the years 1990 through 1995 , the average annual $\mathrm{U}_{3} \mathrm{O}_{\mathrm{s}}$ requirements are projectes to be 38.9 million pounds in all 3 cases (Table 2 and Figure 1). The requirements are projected for the year the $\mathrm{U}_{3} \mathrm{O}_{8}$ is delivered to a conversion plant (15 months pricr to startup of a reactor) and, therefore, depend on reactors projected to begin operating in 1991 through early 1997. Reactors projected to enter commercial operation in 1990 are assumed to have their first core requirements already scheduled. The broad range in 2016 through 2020 is due to the large difference in projections of domestic nuclear power plant capacity. Average annual requirements for $\mathrm{U}_{3} \mathrm{O}_{5}$ are projected to decline 51 percent from their 199()-1995 level by the years 2016 through 2020 in the No New Orders case (where 110 orders for new nuclear reactors are assumed to be placed through 2020). In the Upper Reference case, average annual $\mathrm{U}_{3} \mathrm{O}_{4}$ requirements are projected to grow from 38.9 million pounds in the years 1990 through 1995 to 59.5 million pounds in the years 2016 through 2020, a growth rate of approximately 1.7 percent per year.

The cumulative uranium concentrate requirements in the three cases total slightly more than 430 million pounds through the year 2000 for all three cases (Table 3 and Figure 2). By the year 2010, the No New Orders Cases projects cumulative uranium requirements to be about 799 millicn pounds compared to 866 million pounds in the Upper Reference Case. This represents about a $\&$ percent difference between the two. In 2020, the difference between the two cases is about 39 percent. The wide

\section{Table 2. Projected Average Annual Natural Uranium Requirements for U.S. Nuclear Power Plants, 1990-2020 \\ (Million Pounds $\mathrm{U}_{3} \mathrm{O}_{8}$ Equivalent)}

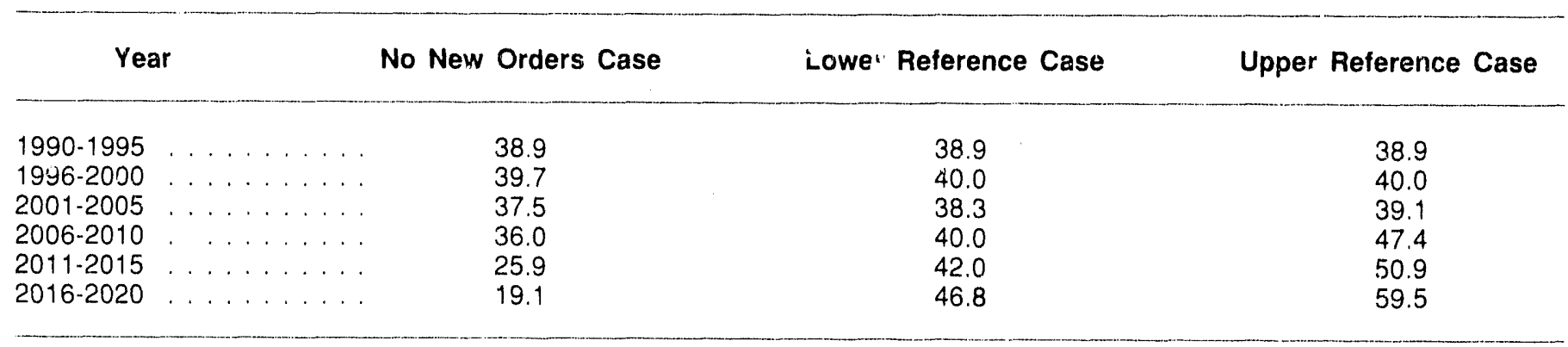

Source: Projected uranium requirements calculated using the International Nuclear Model, based on capacity projections from Energy Information Administration, Commercial Nuclear Power 1990: Prospects for the United States and the World, DOE/EIA-0438(90) (Washington, DC, September 1990). 
Figure 1. U.S. Average Annual Uranium Requirements, 1990-2020

Million Pounds U308 Equivalent

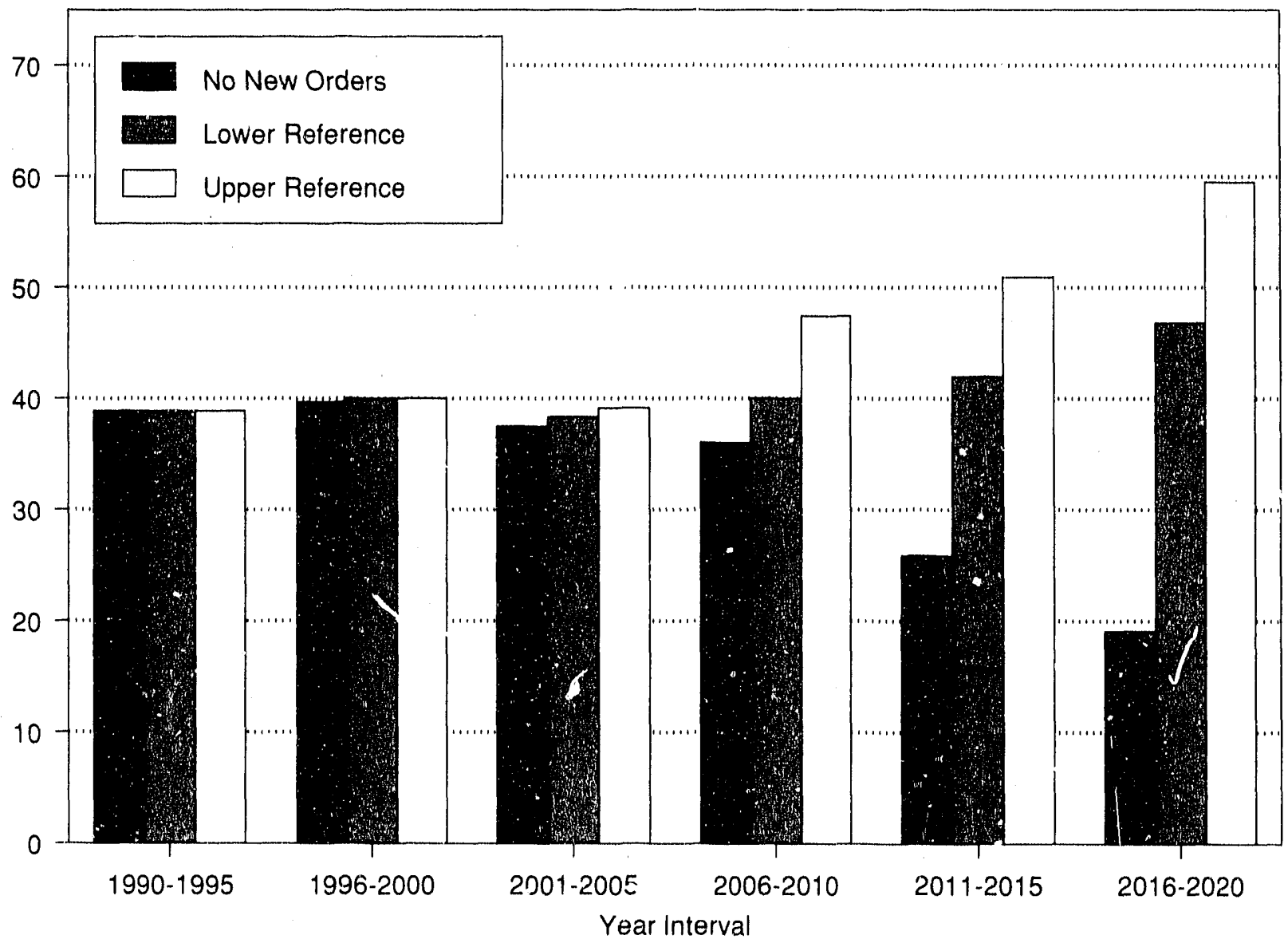

Note: Uranium requirements calculated using the International Nuclear Model.

Source: See Appendix E.

Table 3. Projected Cumulative Natural Uranium Requirements for U.S. Nuclear Power Plants, 1990-2020

(Million Pounds $\mathrm{U}_{3} \mathrm{O}_{8}$ Equivalent)

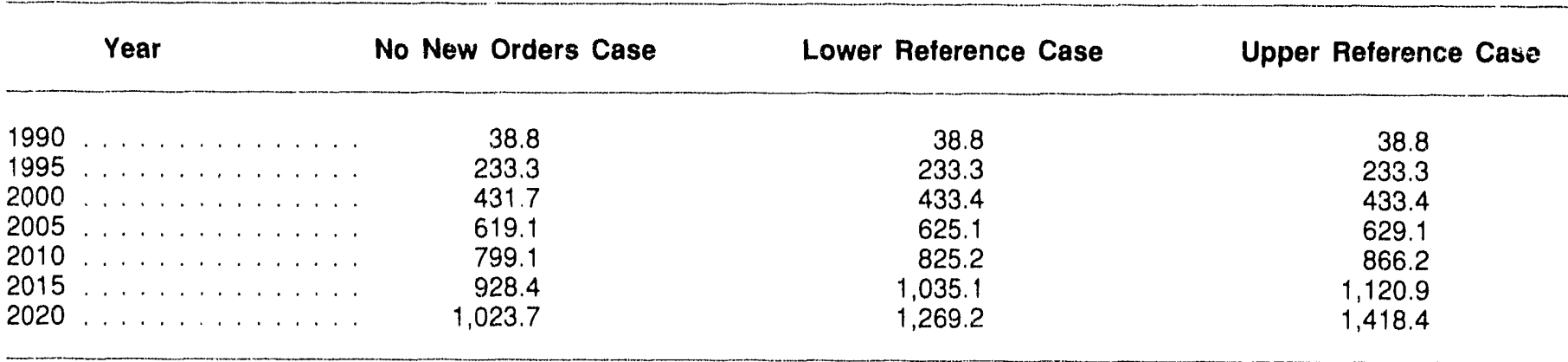

Source: Projected uranium requirements calculated using the International Nuclear Model, based on capacity projections from Energy Information Administration, Commercial Nuclear Power 1990: Prospects for the United States and the World, DOE/EIA-0438(Q0) (Washington, DC, September 1990). 
Figure 2. U.S. Total Uranium Requirements, 1990-2020

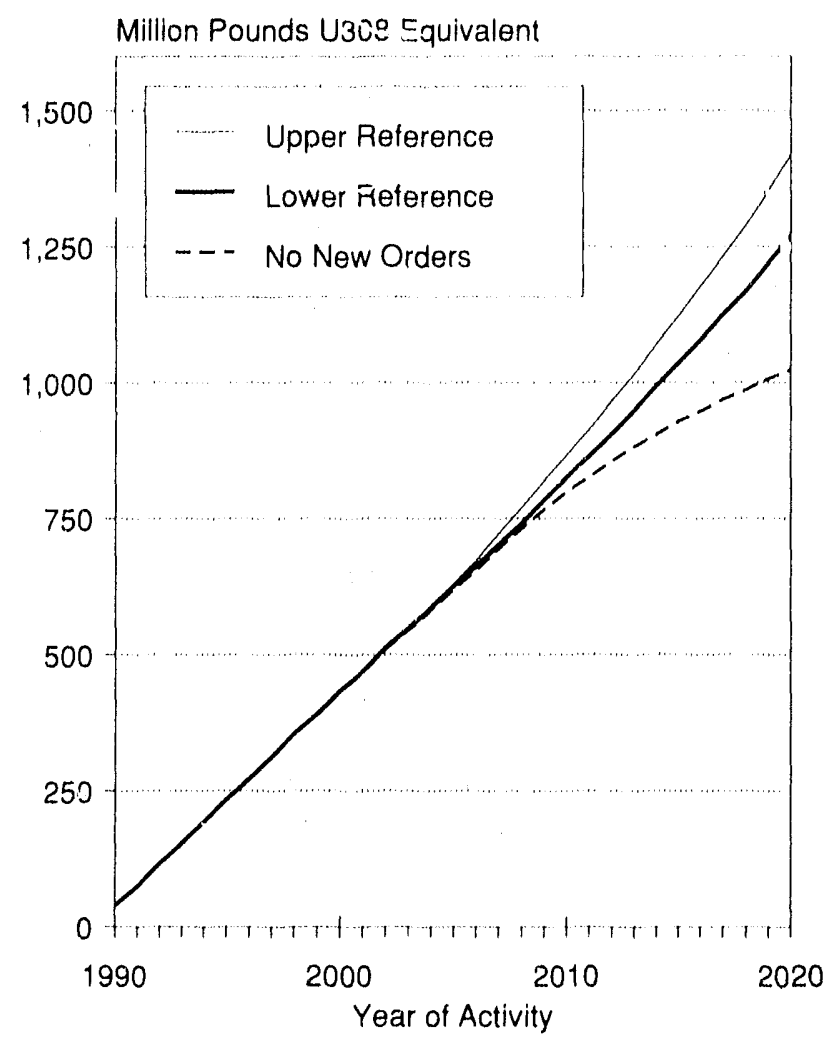

Note: Uranium requirements calculated using the International Nuclear Model.

Source: See Appendix E. ranges for the year 2,10 and beyond are due to the wide divergence in the projected new orders for nuclear power plants and the resulting reyuiremests for uranium concentrate for initial fuel loading and refueling.

\section{U.S. Uranium Enrichment Service Requirements}

Average annual enrichment service recuirements for the three basic scenarios are shown in Table 4 and Figure 3. Under sypical uranium enrichment transaction terms, natural UF, enrichment feed is required 12 months before the start of a reactor's cycle, anci enriched UF" is required 9 months before the start of the cycle. This allows sufficient time for fabricating the fuel into rods and then into assemblies for loading into the core. Similar to the requirements for natural uranium, the projected requirements for enrichment services are not particularly sensitive to different case assumptions through 2005. After 2005, however, the projected average annual enrichment service requirements in the three Reference cases begin to diverge, and by the years 2016 through 2020 there are marked differences in the projections. As mentioned previously, the reason for this difference is because the projected installed capacity is substantially different between these scenarios starting after 2005 . Enrichment service requirements in the No New Orders case differ significantly from those in the other cases after 2005, when the retirement of existing reactors and the introduction of new reactors become the controlling factors. In the years 2016 through 2020 , the projected average annual enrichment service requirements in the No New Orders case are about 35 percent of those in the Upper Reference case.

\section{Table 4. Projected Average Annual Uranium Enrichment Service Requirements for U.S. Nuclear Power Plants, 1990-2020 \\ (Million Separative Work Units)}

\begin{tabular}{|c|c|c|c|}
\hline Year & No New Orders Case & Lower Reference Case & Upper Reference Case \\
\hline $\begin{array}{l}1990-1995 \\
1996-2000 \\
2001-2005 \\
2006-2010 \\
2011-2015 \\
2016-2020\end{array}$ & $\begin{array}{l}8.1 \\
8.8 \\
9.3 \\
9.8 \\
7.3 \\
5.5\end{array}$ & $\begin{array}{r}9.1 \\
8.9 \\
9.5 \\
10.8 \\
11.1 \\
12.6\end{array}$ & $\begin{array}{r}8.1 \\
8.9 \\
9.7 \\
12.6 \\
13.5 \\
15.8\end{array}$ \\
\hline
\end{tabular}

Source: Projected uranium requirements calculated using the International Nuclear Model, based on capacity projections from Energy Information Administration, Commercial Nuclear Power 1990: Prospects for the United States and the World, DOE/EIA-0438(90) (Washington, DC, September 1990). 
Figure 3. U.S. Average Annual Uranilín Enrichment Service Requirements, 1990-2020

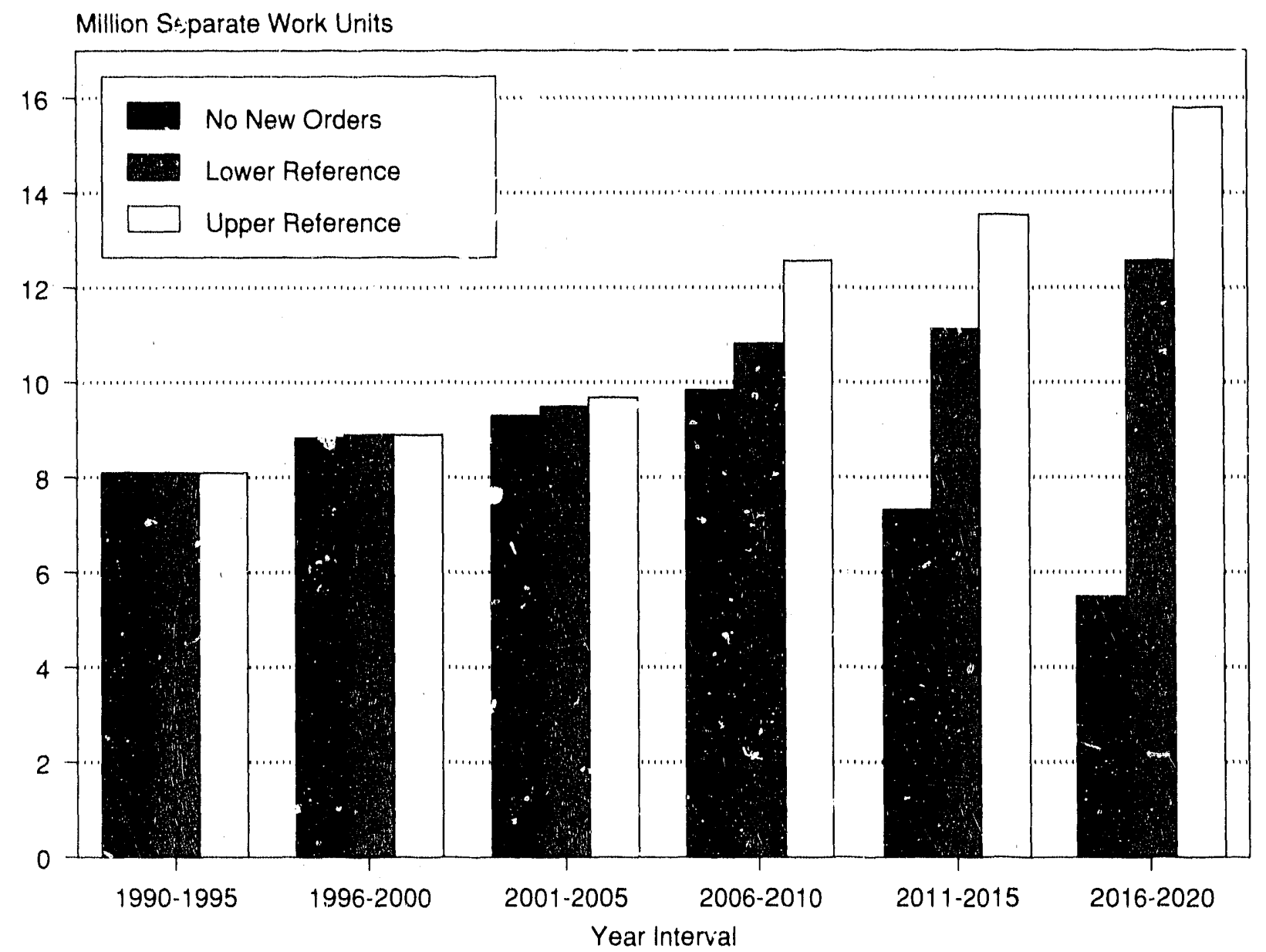

Note: Uranium enrichment service requirements calculatea using the International Nuclear Model.

Source: See Appendix E.

\section{Spent Fuel Discharges}

Average annual projections of spent fuel discharges for the three basic scenarios are presented in Table 5 and in Figure 4. Projections of the total discharges since 1957 are shown in Table 6 and Figure 5. Annual projections of spent fuel discharges represent the spent fuel discharged from reactors whose fuel cycle ended during the year, excluding discharged fuel that is scheduled for reinsertion. Therefore, the annual projections do not increase each year as would be expected if all reactors operated on a $\$ 2$-month cycle. From 1979 through 1985, the length of the fuel cycle for most domestic reactors was 15 to 21 months. In these projections, all reactors are assumed to have approximately 18-month fuel cycles as the design burnups increases. (An alternative to increasing the length of the cycle would be to replace a smaller fraction of the core at each refueling.)

The average annual discharges in the Upper Reference case in 2016 through 2020 are projected to be at 2.5 compared to the 1990 through 1995 discharge levels of 2.0 thousand metric tons of initial heavy metal (Table 5). The total amount of spent fuel discharged (in thousand metric tons of initial heavy metal) is projected in the Upper Reference case to grow to 31.4 in 1995, to 40.4 in the year 2000, and 84.4 in the year 2020 (Table 6 and Figure 5). Through the year 2005, the projections in the different cases are the same. After 2005, the projections begin to diverge until the total amount of spent fuel discharged in the Upper Reference case in the year 2021 is 5.2 percent greater than the Lower Reference cas', and the total spent fuel in the No New Orders cise is 6.7 percent less than the Lower Reference case. 
Table 5. Average Annual Spent Fuel Discharges from U.S. Nuclear Power Plants, 1990-2020 (Thousand Metric Tons of Initial Heavy Metal)

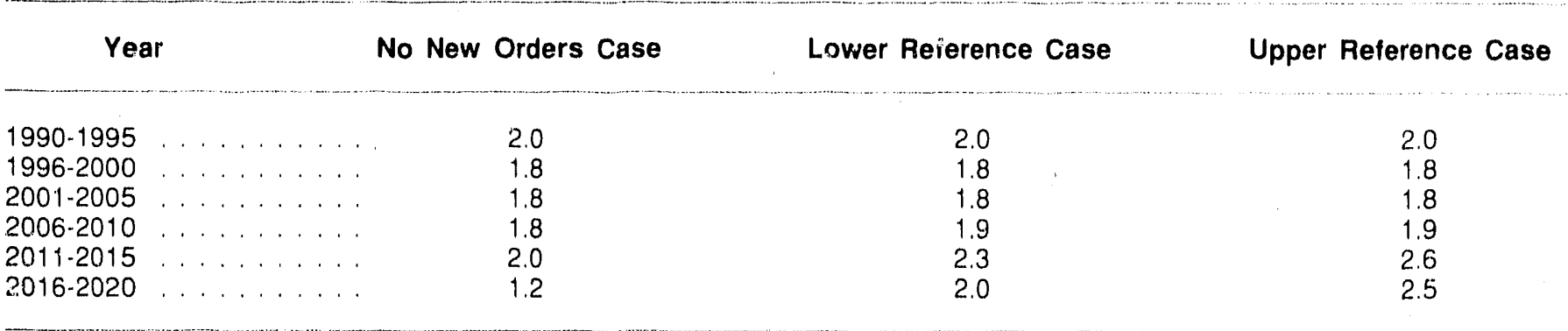

Source: Projected spent fuel discharges calculated using the International Nuclear Model, based on capacity projections from Energy Information Administration, Commercial Nuclear Power 1990: Prospects for the United States and the World, DOE/EIA-0438(90) (Washington, DC, September 1990).

Figure 4. U.S. Average Nuclear Spent Fuel Discharges, 1990-2020

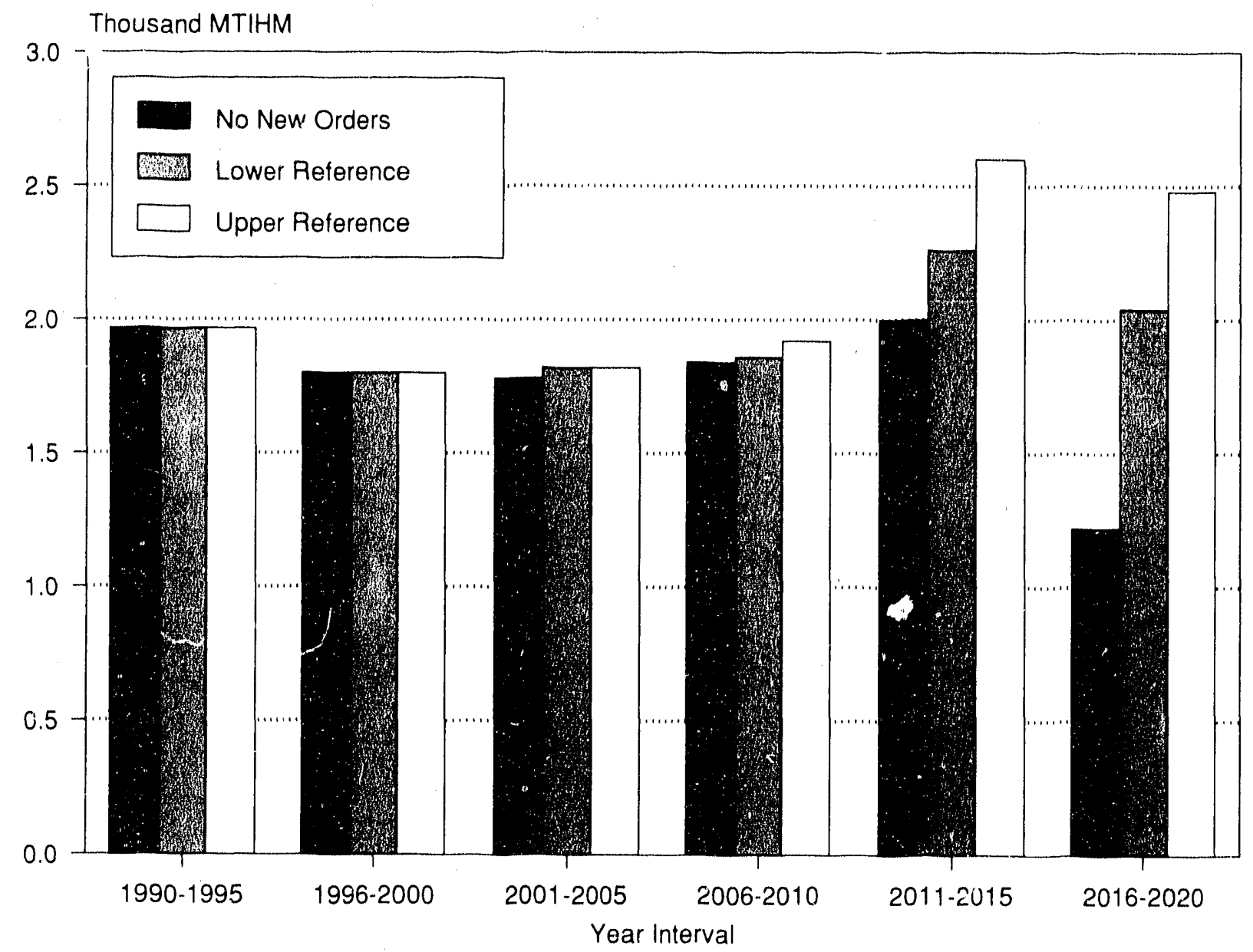

Note: Uranium requirements calculated using the International Nuclear Model.

Source: See Appendix E. 
Table 6. Cumulative Spent Fuel Discharges From U.S. Nuclear Power Plants: Total From 1957" (Thousand Metric Tons of Initial Heavy Metal)

\begin{tabular}{|c|c|c|c|c|}
\hline $\begin{array}{l}1989^{\circ} \\
1990 \\
1995 \\
2000 \\
2005 \\
2010 \\
2015 \\
2020\end{array}$ & $\ldots$ & $\begin{array}{l}19.6 \\
21.8 \\
31.4 \\
40.4 \\
49.4 \\
58.6 \\
68.5 \\
74.8\end{array}$ & $\begin{array}{l}19.6 \\
21.8 \\
31.4 \\
40.4 \\
49.4 \\
58.8 \\
70.0 \\
80.2\end{array}$ & $\begin{array}{l}19.6 \\
21.8 \\
31.4 \\
40.4 \\
49.4 \\
59.1 \\
72.0 \\
84.4\end{array}$ \\
\hline
\end{tabular}

"Total spent fuel discharges include all discharges since 1957 that were not reprocessed by the U.S. Government and are not scheduled for reinsertion (1957 was the inception of commercial nuclear power in the United States).

"Data collected on Form RW-859, "Nuclear Fuel Data" (1989), indicate that 19.6 thousand metric tons of initial heavy metal are in storage as of December 31, 1989. The 19.6 thousand metric tons of initial heavy metal in storage do riot include irradiated nuclear fuel that was reprocessed by the U.S. Government or that will be reinserted in future cycles of the nuclear reactors.

Source: Projected spent fuel discharges calculated using the International Nuclear Model, based on capacity projections from Energy Information Administration, Commercial Nuclear Power 1990: Prospects for the United States and the World, DOE/EIA-0438(90) (Washington, DC, September 1990).

Figure 5. U.S. Total Nuclear Spent Fuel Discharges, 1970-2020

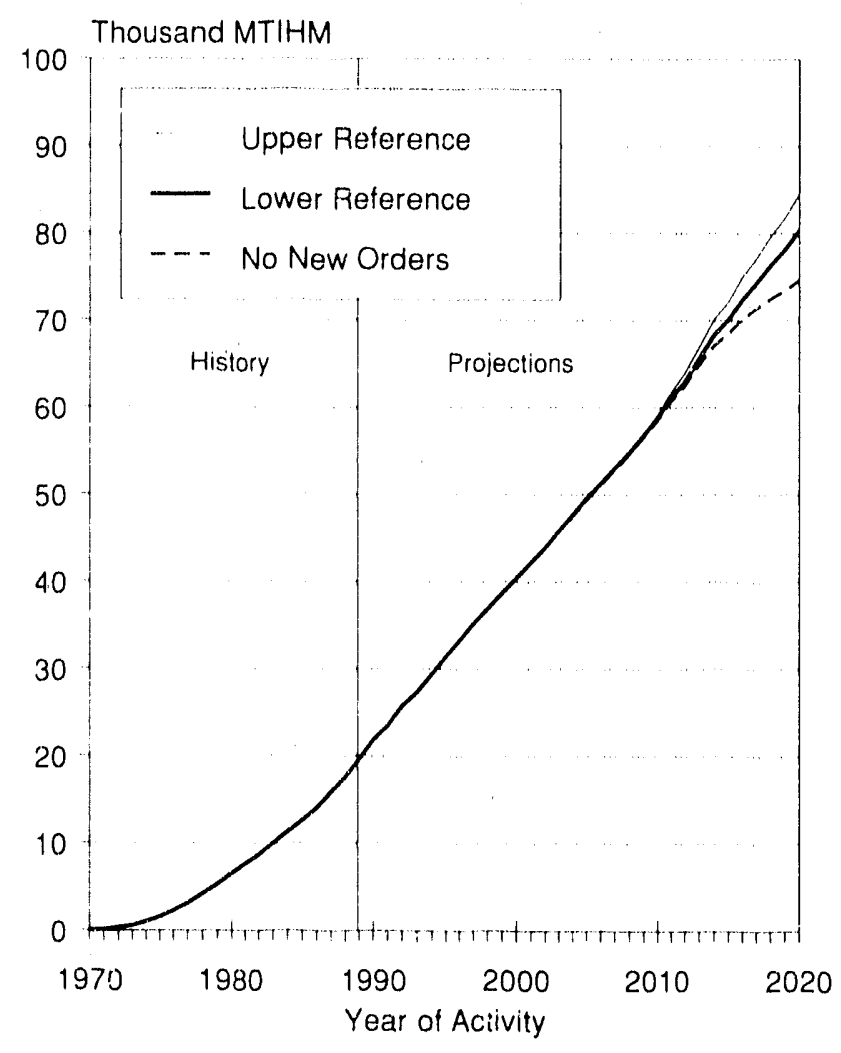

Note: Uranium requirements calculated using the International Nuclear Model.

Source: See Appendix E.

\section{Sensitivity Analyses}

Analyses were performed to determine the sensitivity of the projections to variations in the basic nuclear fuel cycle assumptions. Seven sensitivity studies were developed from the Lower Reference case (Table 7) and the same seven sensitivity cases were also developed for the No New Orders case (Table 8). The seven sensitivity cases are:

- Capacity factors in the equilibrium cycle are 62 percent from 1990 through 2020.

- Capacity factors in the equilibrium cycie increase to 70 percent by 1998 and 74.0 percent by 2020 .

- The enrichment tails assay is 0.2 percent in each year.

- The enrichment tails assay is 0.3 percent in each year.

- No increase in design burnup occurs beyond 1989 levels.

- The design burnup increases at an accelerated pace and increases to 47,000 MWDT/MTIHM for boiling-water reactors in 2010 and to 52,000 MWDT/MTIHM for pressurized-water reactors in 2005 .

- Plant lives are extended to 60 years for 70 percent of installed capacity. 
Table 7. Sensitivity of Lower-Reference-Case Projections of U.S. Nuclear Fuel Cycle Requirements to Alternative Assumptions

\begin{tabular}{|c|c|c|c|c|c|c|c|c|}
\hline & \multirow[b]{2}{*}{$\begin{array}{c}\text { Lower- } \\
\text { Heference- } \\
\text { Case } \\
\text { Value }\end{array}$} & \multicolumn{7}{|c|}{ Percent Differences from Lower-Reference Case Due to Variations In Assumptions } \\
\hline Projection & & $\begin{array}{l}\text { With } \\
\text { Lower } \\
\text { Capacity } \\
\text { Factors }\end{array}$ & $\begin{array}{l}\text { With } \\
\text { Higher } \\
\text { Capacity } \\
\text { Factors }\end{array}$ & $\begin{array}{l}\text { With } \\
\text { Lower } \\
\text { Tails } \\
\text { Assay }\end{array}$ & $\begin{array}{l}\text { With } \\
\text { Higher } \\
\text { Tails } \\
\text { Assay }\end{array}$ & $\begin{array}{c}\text { With No } \\
\text { Increase } \\
\text { in Fuel } \\
\text { Burnup. }\end{array}$ & $\begin{array}{l}\text { With } \\
\text { Higher } \\
\text { Fuel } \\
\text { Burnup }\end{array}$ & $\begin{array}{l}\text { With } \\
\text { Extended } \\
\text { Plant } \\
\text { Lives }\end{array}$ \\
\hline
\end{tabular}

Average Annual Natural Uranium Requirements (million pounds $\mathrm{U}_{3} \mathrm{O}_{8}$ equivalent)

\begin{tabular}{|c|c|c|c|c|c|c|c|c|}
\hline $1990-1995$ & 38.9 & -1.7 & 4.5 & -17.1 & 0.0 & -0.3 & 1.3 & 0.0 \\
\hline $1996-2000$ & 40.0 & -5.1 & 7.3 & -17.1 & 0.1 & -0.1 & -0.2 & 0.1 \\
\hline $2001-2005$ & 38.3 & -5.1 & 9.7 & -11.6 & 6.8 & 3.5 & 0.2 & 0.2 \\
\hline $2006-2010$ & 40.0 & -7.7 & 7.4 & -8.4 & 10.6 & 0.1 & 2.6 & 3.4 \\
\hline $2011-2015$ & 42.0 & -11.7 & 7.8 & -8.6 & 10.4 & 1.0 & 4.2 & 18.2 \\
\hline $2016-2020$ & 46.8 & -6.1 & 7.0 & -8.5 & 10.6 & 1.5 & 7.9 & 25.1 \\
\hline
\end{tabular}

Total Natural Uranium Requirements (million pounds $U_{j} O_{\theta}$ equivalent)

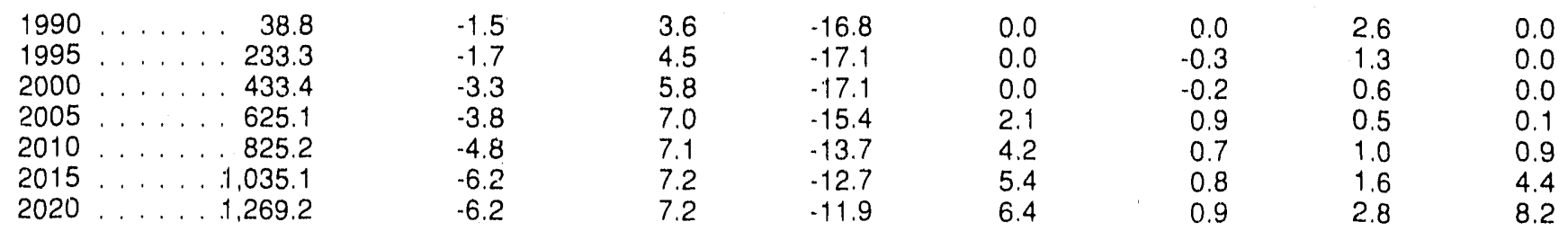

Average Annual Uranium Enrichment Service Requirements (million separative work units)

\begin{tabular}{|c|c|c|c|c|c|c|c|c|}
\hline $1990-1995$ & 8.1 & -2.3 & 5.4 & 24.8 & 0.0 & -0.4 & 1.4 & 0.0 \\
\hline $1996-2000$ & 8.9 & -7.4 & 6.0 & 24.3 & 0.0 & -6.1 & 2.4 & 0.0 \\
\hline $2001-2005$ & 9.5 & -2.3 & 10.1 & 16.8 & -5.9 & 0.0 & 4.8 & 0.3 \\
\hline $2006-2010$ & 10.8 & -9.4 & 10.0 & 12.3 & -9.6 & -5.4 & 6.7 & 2.9 \\
\hline $2011-2015$ & 11.1 & -6.2 & 5.5 & 12.3 & -9.6 & -4.8 & 7.1 & 18.0 \\
\hline $2016-2020$ & 126 & 73 & & & & & & \\
\hline
\end{tabular}

Average Arnual Spent Fuel Discharges (thousand metric tons of initial heavy metal)

\begin{tabular}{|c|c|c|c|c|c|c|c|c|}
\hline $1990-1995$ & 2.0 & -3.4 & 1.7 & 0.0 & 0.0 & 0.0 & 0.0 & 0.0 \\
\hline $1996-2000$ & 1.8 & -1.1 & 8.9 & 0.0 & 0.0 & 6.7 & -3.3 & -1.1 \\
\hline $2001-2005$ & 1.8 & -7.7 & 8.8 & 0.0 & 0.0 & 11.0 & -3.3 & -1.1 \\
\hline $2006-2010$ & $i .9$ & -4.3 & 9.7 & 0.0 & 0.0 & 17.2 & -2.2 & -2.2 \\
\hline $2011-2015$ & 2.3 & -6.2 & 2.7 & 0.0 & 0.0 & 13.3 & -2.7 & -4.4 \\
\hline $2016-2020$ & 2.0 & .5 .9 & 3.9 & 0.0 & 0.0 & 15.7 & 1.0 & 14.7 \\
\hline
\end{tabular}

Total Spent Fuel Discharges (thousand metric tons of initial heavy metal)

\begin{tabular}{|c|c|c|c|c|c|c|c|c|}
\hline 1990 & 21.8 & 0.0 & 0.0 & 0.0 & 0.0 & 0.0 & 0.0 & 0.0 \\
\hline $1 \exists 95$ & 31.4 & -0.6 & 1.0 & 0.0 & 0.0 & 0.0 & 0.0 & 0.0 \\
\hline 2000 & 40.4 & -1.0 & 3.0 & 0.0 & 0.0 & 1.5 & -0.2 & 0.0 \\
\hline 2005 & 49.4 & -2.2 & 4.0 & 0.0 & 0.0 & 3.6 & -0.8 & 0.0 \\
\hline 2010 & 58.8 & -2.7 & 4.8 & 0.0 & 0.0 & 5.4 & -1.0 & -0.5 \\
\hline 2015 & 70.0 & -3.1 & 4.7 & 0.0 & 0.0 & 6.9 & -0.5 & -1.0 \\
\hline 2020 & 80.2 & -3.4 & 4.6 & 00 & 00 & 8.0 & -0.7 & 10 \\
\hline
\end{tabular}

"Cumulative from 1957.

Source: Projected fuel cycle requirements calculated using the International Nuclear Model, bazed on capacity projections from Energy Information Administration, Commercial Nuclear Power 1990: Prospects for the United states and the World, DOE/EIA-0438(90) (Washington, DC, September 1990). 
Table 8. Sensitivity of No-New-Orders-Case Projections of U.S. Nuclear Fuel Cycle Requirements to Alternative Assumptions

\begin{tabular}{|c|c|c|c|c|c|c|c|c|}
\hline & \multirow[b]{2}{*}{$\begin{array}{c}\text { No-New- } \\
\text { Orders- } \\
\text { Case } \\
\text { Value }\end{array}$} & \multicolumn{4}{|c|}{ Percent Differences from $\mathrm{N}$} & \multicolumn{3}{|c|}{ Due to Variations in Assumptions } \\
\hline Projection & & $\begin{array}{l}\text { With } \\
\text { Lower } \\
\text { Capacity } \\
\text { Factors }\end{array}$ & $\begin{array}{l}\text { With } \\
\text { Higher } \\
\text { Capacity } \\
\text { Factors }\end{array}$ & $\begin{array}{l}\text { With } \\
\text { Lower } \\
\text { Tails } \\
\text { Assay }\end{array}$ & $\begin{array}{l}\text { With } \\
\text { Higher } \\
\text { Tails } \\
\text { Assay }\end{array}$ & $\begin{array}{l}\text { With No } \\
\text { Increase } \\
\text { in Fuel } \\
\text { Burnup }\end{array}$ & $\begin{array}{l}\text { With } \\
\text { Higher } \\
\text { Fuel } \\
\text { Burnup }\end{array}$ & $\begin{array}{c}\text { With } \\
\text { Extended } \\
\text { Plant } \\
\text { Lives }\end{array}$ \\
\hline
\end{tabular}

Average Annual Natural Uranium Requirements (million pounds $U_{3} \mathrm{O}_{3}$ equivalent)

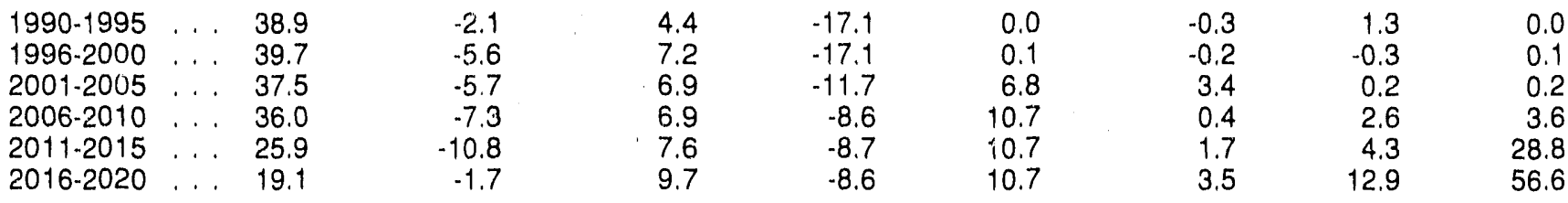

Total Natural Uranium Requirements (million pounds $\cup_{3} O_{8}$ equivalent)

\begin{tabular}{|c|c|c|c|c|c|c|c|c|}
\hline 1990 & 38.8 & -2.1 & 3.6 & -16.8 & 0.0 & 0.0 & 2.6 & 0.0 \\
\hline 1995 & 233.3 & -2.1 & 4.4 & -17.1 & 0.0 & -0.3 & 1.3 & 0.0 \\
\hline 2000 & 431.7 & -3.7 & 5.7 & -17.1 & 0.0 & -0.2 & 0.6 & 0.0 \\
\hline 2.005 & 619.1 & -4.3 & 6.0 & -15.5 & 2.1 & 0.9 & 0.5 & 0.1 \\
\hline 2010 & 799.1 & -5.0 & 6.2 & -13.9 & 4.0 & 0.8 & 0.9 & $\mathrm{u} . \mathrm{s}$ \\
\hline 2015 & 928.4 & -5.8 & 6.4 & -13.2 & 4.9 & 0.9 & 1.4 & 4. \\
\hline 20 & $1,023.7$ & -5.4 & 6.7 & -12.7 & 5.5 & 1.1 & 2.5 & 9 \\
\hline
\end{tabular}

Average Annual Uranium Enrichment Service Requirements (million separative work units)

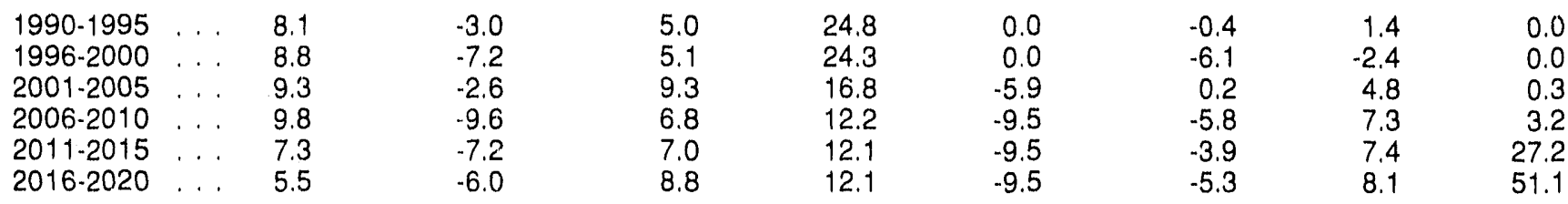

Average Annual Spent Fuel Discharges (thousand metric tons of initial heavy metal)

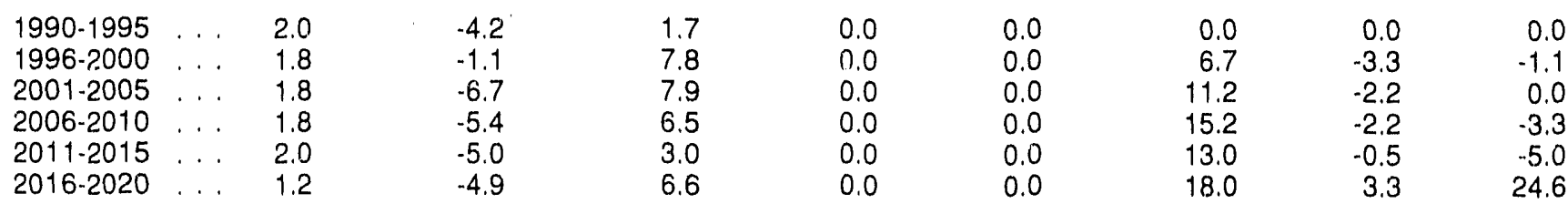

Total Spent Fuel Discharges (thousand metric tons of initial heavy metal) ${ }^{\text {a }}$

\begin{tabular}{|c|c|c|c|c|c|c|c|c|}
\hline 1990 & 21.8 & 0.0 & 0.0 & 0.0 & 0.0 & 0.0 & 0.0 & 0.0 \\
\hline 1995 & 31.4 & -1.3 & 1.0 & 0.0 & 0.0 & 0.0 & 0.0 & 0.0 \\
\hline 2000 & 40.4 & -1.2 & 2.7 & 0.0 & 0.0 & 1.5 & -0.2 & 0.0 \\
\hline 2005 & 49.4 & -2.2 & 3.2 & 0.0 & 0.0 & 3.4 & -0.8 & -0.2 \\
\hline 2010 & 58.6 & -2.9 & 3.8 & 0.0 & 0.0 & 5.3 & -1.2 & -0.5 \\
\hline 2015 & 68.5 & -2.9 & 3.9 & 0.0 & 0.0 & 6.7 & -0.9 & 1.2 \\
\hline 2020 & 74.8 & -3.5 & 3.7 & 0.0 & 0.0 & 7.4 & -0.9 & 0.8 \\
\hline
\end{tabular}

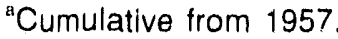

Source: Projected fuel cycle requirements calculated using the International Nuclear Model, based on capacity projections from Energy Information Administration, Commercial Nuclear Power 1990: Prospects for the United States and the World, DOE/EIA-0438(90) (Washington, DC, September 1990). 


\section{Capacity Factors}

In 1989, the average capacity factor was 62.3 percent, a decline from the exceptionally high 1988 rate of 6.3.5 percent, but still higher than any other year since 1978 .

Industry efforts to improve plant maintenance, upgrade the equipment, modernize control systems, improve employee training, and share information about operational problems through the Institute of Nuclear Power Operators and the World Association of Nuclear Operators support the assumption used in all three base cases of increasing capacity factors.

In the low-capacity-factor sensitivity study, the annual equilibrium cycle capacity factors are kept at approximately 62 percent from 1990) through 2020. In the high-capacity-factor study, the equilibrium-cycle capacity factors increase to 70 percent by 1998 and to 74 percent by 2020 . There is some variation in the capacity factors from year-to-year however.

Capacity factors affect the nuclear generation and the length of time required to achieve full burnup of the nuclear fuel. In general, lower capacity factors decrease both uranium and enrichment services requirements. For example, in the 2005 through 2010 year span, the projected average annual $\mathrm{U}_{3} \mathrm{O}_{k}$ and enrichment requirements for the low capacity factor case are 7.7 and 9.4 percent less, respectively, than for the Lower Reference case, and 6.1 and 7.3 percent less in the 2016 through 2020 year period. Total spent fuel discharges are 3.4 percent less by 2020. In the high capacity factor case, the change from the Lower Reference case in average annual $U_{1} O_{x}$ and enrichment service requirements in 2006 through $201($ ) is an increase of 7.4 and $10 .()$ percent, respectively. The total spent fuel discharges are 4.6 percent higher by 2020. Similar differences result when the nuclear supply of the No New Orders case is used for the sensitivity cases.

\section{Enrichment Tails Assay}

Current enrichment contracting options allow utilities to specify the transaction tails assay under which natural uranium is enriched. The tails assay can typically be specified over a range of 0.20 to 0.30 percent U-235. The tails assay specifications do not affect the amount of spent fuel discharged. However, within the $(.20$ to 0.30 percent range, the average tails assay specification affects the enrichment separative work requirements and the natural uranium enrichment feed requirements significantly. For example, a tails assay of 0.2 percent increases the average annual uranium enrichment service requirements by 24.8 percent in the years 1990 through 1995. In general, higher tails assays connote' higher uranium concentrate requirements and lower separative work requirements to produce a given quantity of enriched uranium fuel and lower tails assay connote lower uranium reguirements and higher separative work requirements. Thus, there is a natural flexibility, or tradeoff, between the requirements for natural uranium and enrichment requirements, depending on the tails assay selected. In turn, the average tails assaly selected by the utilities is largely dependent on the relative prices of natural uranium and separative work. The utilities typically specify tails assays that minimize the cost of enriched fuel.

The tails assays assumptions for the three basic nuclear supply scenarios are:

$\begin{array}{ll}199(0)-2(0) 0) & 0.30 \text { percent } \\ 2001 & 0.29 \text { percent } \\ 20(1) & 0.28 \text { percent } \\ 2003 & 0.27 \text { percent } \\ 20(1) 4 & 0.26 \text { percent } \\ 2005-2020 & 0.25 \text { percent }\end{array}$

The higher tails assay sensitivity case specifies a 0.30 percent transaction tails assay for the entire projection period. The lower tails assay sensitivity case represents a reversion to the historical 0.20 percent average tails assay. The changes in uranium requirements and separative work requirements due to the adjustments in tails assay (after 1989) are shown in Table 7 and Table 8.

Average annual uranium requirements for the lower tails assay sensitivity case of the Lower Reference decrease by 17.1 percent in the years 1990 through 1995 , and decrease by 8.5 percent in the years 2016 through 2020. On the other hand, enrichment service requirements increase by 24.8 percent in the period 1990 through 1995 and 12.3 percent for the 2.016-2(120) period for the lower tails assay sensitivity case. The No New Orders supply scenario shows similar results in uranium and enrichment services requirements when the tails assay assumption is changed. Spent fuel discharges are not affected by tails assay options.

\section{Fuel Burnup Levels}

$S$ ime electric utilities have been increasing the burnup of their nuclear fuel with indications that they plan to continue increasing burnup in the future. Burnup can be defined as the amount of energy produced per metric ton of enriched uranium. Figure 6 displays actual average equilibrium cycle burnup levels by year from 1972 through 1989 for boiling-water reactors. Also shown are projected average annual equilibrium cycle burnup values for the No New Orders case scenarios for 1990 through 2010. Figure 7 displays similar data for pressurized-water reactors. 


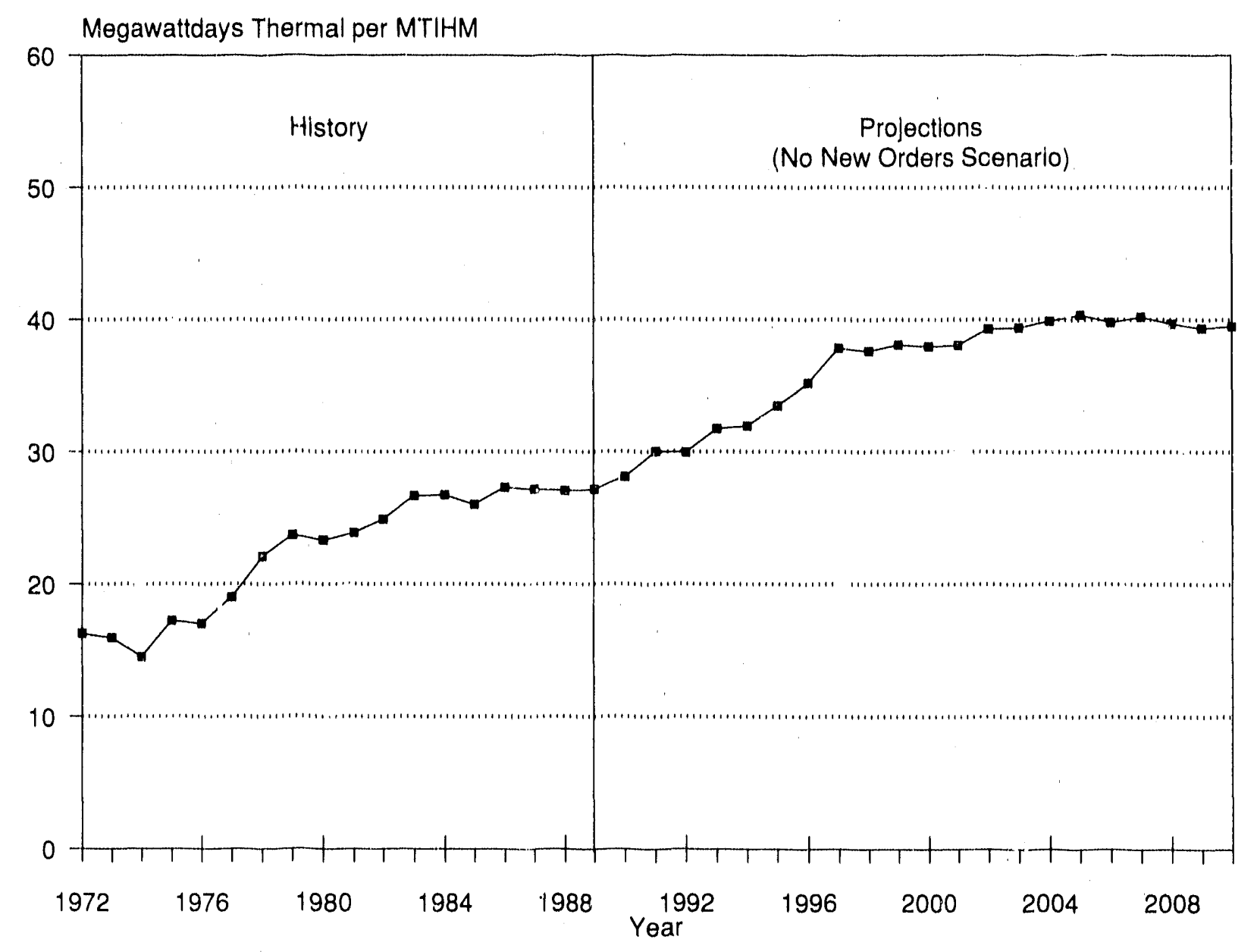

Note: Projected average equilibrium-cycle discharge burnup calculated using the International Nuclear Model. Source: See Appendix E.

The average discharge burnup for BWR's is projected to reach $3 \&, 000$ by the year 2000 and 46,000 by the year 2000 for PWR's. Fuel use in boiling-water reactors tends to be in the lower end of the burnup range, whereas fuel used in pressurized-water reactors tends to be in the Upper end of the range. As a result of a successful cooperative effort between Government and inciustry, fuel with design burnup levels up to 50,000 MWDT/MTIHM for boiling-water reactors and 60,000 for pressurized-water reactors is currently available from commercial vendors.

Increases in burnup are achieved by increasing the concentration of U-235 in the enriched uranium product and by changing the design specifications of the fuel rods to allow for longer in-core exposures. Increased burnup can result in a smaller fraction of the core being replaced during refueling and the length of the operating cycle can also be increased. Up to a given point, the total fuel costs decrease as burnup increases. The burnup level for achieving minimum cost is a function of design parameters and cost components of the fuel cycle. Utilities use higher fuel burnup to reduce fuel costs, increase cycle lengths, and reduce spent fuel generation. Increasing the cycle length means reducing the relative outage time: for example, an annual cycle requires three refuelings in a 3 -year period, while an 18 -month cycle requires only two refuelings in 3 years. Theoretically, increased cycle lengths also imply improved capacity factors.

For all base case scenarios, increases in design burnup are shown in Appendix B, Table B3. The average equilibrium cycle lengths were assumed to be approximately 18 months. 
Figure 7. Average Equillbrium-Cycle Discharge Burnup for U.S. Pressurized-Water Reactors, 1972-2010

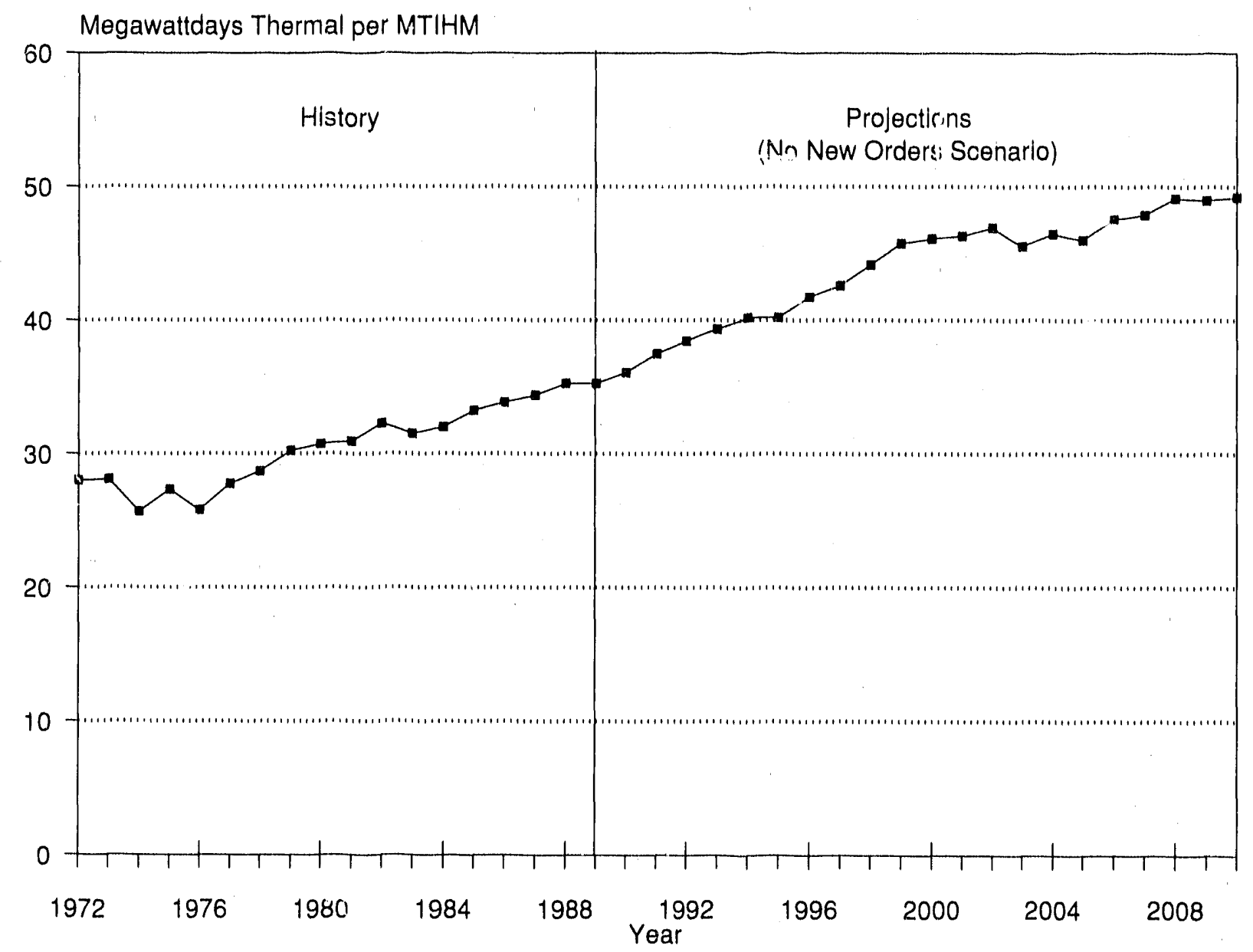

Note: Projected average equilibrium-cycle discharge burnup calculated using the International Nuclear Model. Source: See Appendix E.

Lower and higher burnup sensitivity cases for the Lower Reference and No New Orders cases were analyzed. These cases provided a range within which projected spent fuel discharges should fall. In the lower burnup case, the design burnup level was assumed to remain constant at about 34,000 MWDT/ MTIHM for BWR's and 39,000 MWDT/MTIHM for PWR's. In the higher burnup case, design burnup is increased more rapidly than in the base cases and design burnup is also increased further out in the projection period. For example, design burnup reaches about 42,000 MWDT/MTIHM for PWR's in 1992 compared to 1993 in the base case and about 48,000 MWDT/MTIHM for PWR's in 2001 compared to 2005 in the base case.

In the Lower Reference Case, higher burnup increases average annual uranium requirements by 1.3 percent in 1990 through 1995 and by almost 8 percent in 2016 through 2020. The reason for this is because higher burnup requires a larger U-235 enrichment assay which in turn translates into more $\mathrm{U}_{3} \mathrm{O}_{\mathrm{H}}$. On the other hand, higher burnup decreases total spent fuel discharges by about 1 percent from the Lower Reference Case over the projection period. Similar results occur for higher burnup sensitivity in the No New Order base case. In the no increase in fuel burnup case, the spent fuel inventory becomes greater than in the Lower and No New Orders base cases by the year 2000 and is projected to be 8.0 percent and 7.4 percent higher, respectively, by 2020 .

Reduction in the expected fuel burnup also affect the requirements for natural uranium and for enrichment service. For example, wh an lower burnup is assumed, the total requirements for $\mathrm{U}_{3} \mathrm{O}_{\mathrm{H}}$ increase by 1.1 percent by the year 2020 in the No New Orders 
case because the reactors are less efficient in their fuel utilization.

\section{Plant Life Expectancy}

The three basic scenarios assume a uniform plant life of 40 years. When this assumption is changed to a 60)-year life expectancy for 70 percent of the operating nuclear capacity, electricity gencration from nuclear power in the No New Orders case is unchaiged until the year 2000. By the year 2020, over 50 percent more power is produced annually. By the year 2015, the total projected natural urantum reculrements are increased to a level 4.8 percent greater than that projected assuming a 40-year life expectancy; by the year 2(020, the cumulative projected uranim requirenionts a"9 9.6 percent higher than in the No New Orders case. For total projected spent fuel discharges, extended plant life has little effect over the projection period. Average annual enrichment sorvice requirements show only a modest change until the years 2011-2015 when the average increases by 27.2 percent. The Lower Reference Case shows a similar sensitivity to extended plant life. 


\section{Projections of Nuclear Fuel Cycle Requirements for the Free Market Economies}

\section{Introduction}

This chapter presents projections of nuclear fuel cycle requirements-both uranium concentrate $\left(\mathrm{U}_{3} \mathrm{O}_{H}\right)$ and uranium enrichment services-and spent fuel discharges for each of the five groups of countries that constitute the Free Market Ecunomies (FME), as well as the FME total. These projections are based on the projections of domestic nuclear power plant capacity that were presented in Chapter 2 and projections of foreign capacity. The projections of FME comm" 11 nuclear power capacity for :arious reactors arc usted in Table 9. By the end of 1989, 245 nuclear reactors representing 175.8 net GWe, were operable in the FME countries, excluding the United States. Another 70 reactors, totaling 64.5 net GWe, were in the construction pipeline. The projections of nuclear capacity in foreign FME countries in the year 2010 range from 215.7 net GWe in the Lower Reference case to 252.8 net GWe in the Upper Reference case. The basic assumptions used for the projections are as follows:
- Capacity factors range from 67 percent to 71 percent over the projection period. This is an average for all FME countries (including the United States).

- Enrichment tails assay for light-water reactors is kept constant at 0.25 percent over the projection period (excluding the United States, which was noted above).

- Design burnup goes from about 32,000 MWDT/ MTIHM in 1990) to 44,000 MWDT/MTIHM in 2000 and beyond for boiling-water reactors, and from about 34,000 MWDT/MTIHM in 1990 to 49,000 MWDT/MTIHIM in 2000 and beyond for pressurized-water reactors. Appendix B shows specific design burnup assumptions by year and other important factors about the fuel pians.

- Plants are retired after 30 years of operation.

Table 9. Projected Capacity of Foreign Nuclear Power Plants in the Free Market Economies, 1990-2010 (Net GWe)

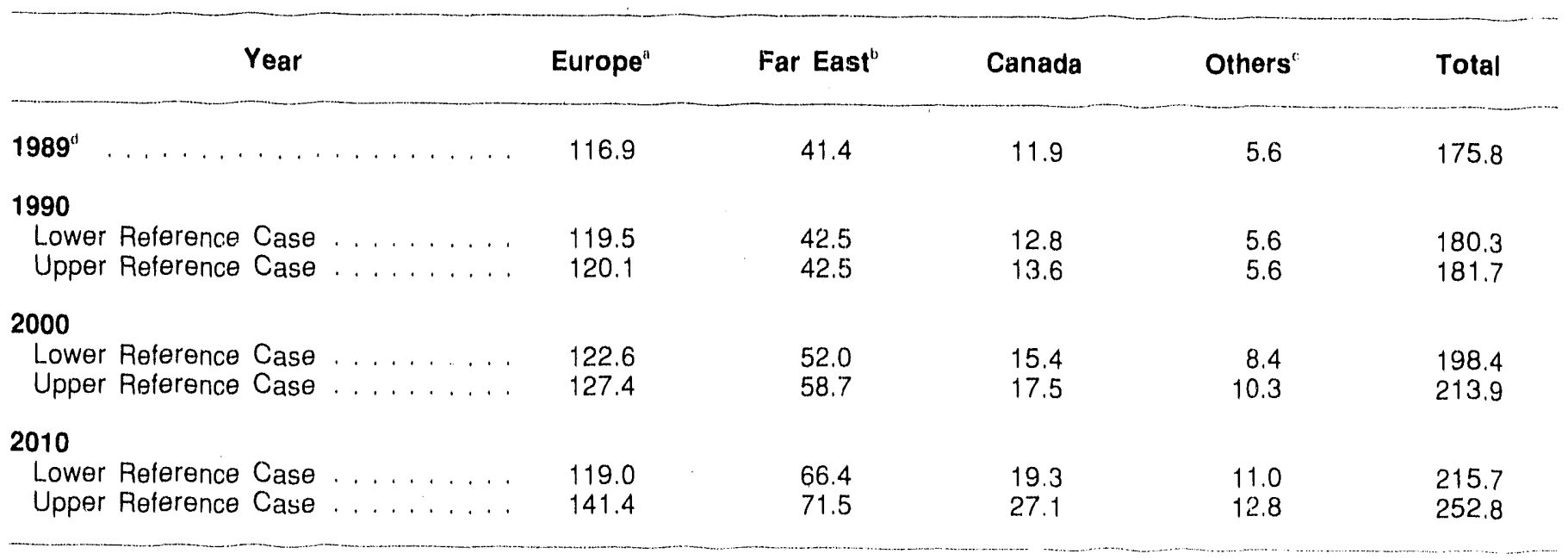

"Includiss Austria, Belgium, Finland, France, Greece, Italy, the Netherlands, Portugal, Spain, Sweden, Switzerland, Turkey, the United Kingdom, Yugoslavia, and West Germany.

Includes Japan, South Korea, and Talwan.

"Includes Argentina, Brazil, Egypt, India, Israel, Mexico, Pakistan, and South Africa.

'Actual data.

Nole: Totals may not equal sum of components due to independent rounding.

Source: Energy Information Administration, Commercial Nuclear Power 1990: Prospects for the United States and the World, DOE/EIA-0438(90) (Washington, DC, September 1990). 
These assumptions differ from those used for the United States for the following reasons. Capacity factcrs and design burnup assumptions are based on analyses of trends in the historical data for domestic and foreign reactors. Assumptions regarding the enrichment tails assay for domestic reactors are also based on historical data; however, no similar historical data are available at this time for foreign reactors. Judgmentally, the midpoint between 0.2 and $(0.3$ percent was selected for the enrichment tails assay for FME reactors. Plant life for domestic reactors is based on the operating license period established by the U.S. Nuclear' Regulatory Commission. In order to have a common assumption for the other FME countries, it was decided to use a 30-year operating life, which coincides with the conventional 30-year economic life assumption.

At the end of 1989 , reactors in countries other than the United States accounted for about 64 percent of the total FME commercial nuclear capacity. About 80 percent of this foreign capacity consisted of lightwater reactors; the remainder of the capacity consisted of gas-cooled reactors, advanced gas-cooled reactors, pressurized heavy-water reactors, and fast breeder reactors. The light-water reactors require periodic refueling. The gas-cooled reactors, which are primarily in the United Kingdom, and pressurized heavy-water reactors, which are primarily in Canada, have on-line refueling capability. The results presented in this chapter account for the different fuel cycle requirements of each reactor type represented in FME countries. It is important to note that the base case fuel cycle requirements (i.e, uranium concentrate requirements and separative work requirements do not account for the possibility of using recycled uranium or the use of mixed oxide fuel (MOX). Data on specific use of recycled uranium in foreign countries is not included in this year's report. However, data on the use of MOX fuel is used to provide a sensitivity case.

For these projections, the FME nations are aggregated as follows:

- The United States

- Canada

- Europe (Austria, Belgium, Finland, France, Greece, Italy, the Netherlands, Portugal, Spain, Sweden, Switzerland, Turkey, the United Kingdom, West Germany, and Yugoslavia) ${ }^{4}$
- The Far East (Japan, South Korea, and Taiwan)

- Other countries (Argentina, Brazil, Egypt, India, Israel, Mexico, Pakistan, and South Africa)

- Total FME.

\section{Uranium Concentrate Requirements}

Average annual requirements for $\mathrm{U}_{3} \mathrm{O}_{4}$ in the FME nations, including the United States, are expected to increase in the Upper Reference case from 113.0 in the years 1990) through 1995 to 147.9 in the years 2006 through 2010, representing a 31 percent increase (Table 10 and Figure 8). During the same interval, the annual FME requirements for $\mathrm{U}_{3} \mathrm{O}_{4}$ are projected to increase by about 14 percent in the Lower Reference case. This projected growth in uranium requirements is slightly less than the projected growth in nuclear capacity, due principally to the expected increase in nuclear fuel burnup.

The U.S. and Europe are projected to account for about 77 percent of the annual FME requirements for uranium in the near term, 1990 through 1995. By 2006 through 2010, the annual requirements for the Far East will increase by more than 50 percent, causing its share of annual FME requirements to increase to approximately 23 percent in the Lower Reference Case.

The spread between the Lower-Reference- and UpperReference-case projections of average annual $\mathrm{U}_{3} \mathrm{O}_{8}$ requirements for the FME countries are projected to grow from about 2 percent in 1990 through 1995 to 17 percent in 2006 through 2010.

Total (cumulative) requirements for uranium in the FME countries are projected to increase from 109.9 million pounds in 1990 to about 2.4 billion pounds by the end of 2010 in the Lower Reference case (Table 11 and Figure 9). The difference between projected total FME requirements for uranium for the Upper and Lower Reference cases grows from less than 1 percent in 1990) to about 8 percent by 2010 . For the "other countries" group, the Upper Reference case is about 25 percent greater than the Lower Reference case in 2010 signifying a great deal of uncertainty between the 2 scenarios.

The Socialist Federal Republic of Yugoslavia participates in certain work of the Organization for Ecomomic Cooperation and Development (agreement of October 28, 1961). 
Table 10. Projected Average Annual Uranium Requirements for Nuclear Power Plants in the Free Market Econumies, 1990-2010

(Million ounds $\mathrm{U}_{3} \mathrm{O}_{3}$ Equivalent)

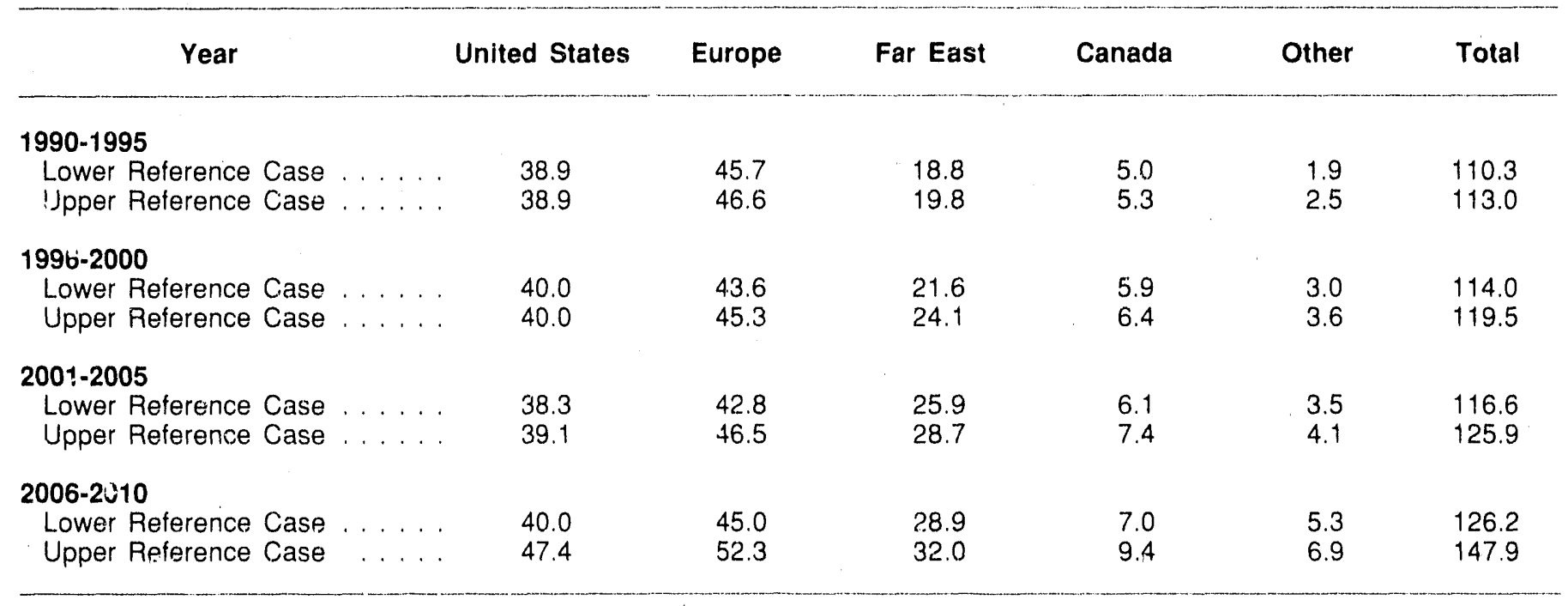

Note: Totals may not equal sum of components due to independent rounding.

Source: Projected uranium requirements calculated fiom Energy Information Administration, Commercial Nuclear Power 1990: Prospects for the United States and the World, DOE/EIA-0438(90) (Washington, DC, September 1990).

Table 11. Projected Cumulative Uranium Requirements for Nuclear Power Plants in the Free Market Economies, 1990-2020

(Million Pounds $\mathrm{U}_{3} \mathrm{O}_{8}$ Equivalent)

\begin{tabular}{|c|c|c|c|c|c|c|c|}
\hline Year & & United States & Europe & Far East & Canade: & Other & Tota \\
\hline \multicolumn{8}{|l|}{1990} \\
\hline Lower Reference Case & $\ldots \ldots$ & 38.8 & 47.5 & 18.4 & 4.1 & 1.1 & 109.9 \\
\hline Upper Reference Case & . & 38.8 & 47.5 & 18.4 & 4.5 & 1.1 & 110.3 \\
\hline \multicolumn{8}{|l|}{1995} \\
\hline Lower Reference Case & $\ldots \ldots$ & 233.3 & 274.3 & 112.9 & 30.0 & 11.1 & 661.6 \\
\hline Upper Reference Case & $\ldots$ & 233.3 & 279.3 & 119.2 & 31.7 & 14.7 & 678.2 \\
\hline \multicolumn{8}{|l|}{2000} \\
\hline Lower Reference Case & $\ldots \ldots$ & 433.4 & 491.8 & 220.9 & 59.5 & 25.9 & $1,231.8$ \\
\hline Upper Referense Case & $\ldots \ldots$ & 433.4 & 505.9 & 239.7 & 63.9 & 32.7 & $1,275.6$ \\
\hline \multicolumn{8}{|l|}{2005} \\
\hline Lower Reference Case & $\ldots \ldots$ & 625.1 & 706.3 & 350.2 & 89.8 & 43.4 & $1,814.6$ \\
\hline Upper Reference Case & $\ldots \ldots$ & 629.1 & 738.3 & 383.2 & 101.1 & 53.3 & $1,905 . C$ \\
\hline \multicolumn{8}{|l|}{2010} \\
\hline Lower Reference Case & $\ldots \ldots$ & 825.2 & 931.5 & 494.9 & 124.6 & 69.8 & $2,446.0$ \\
\hline Upper Reference Case & & 866.2 & 999.9 & 543.1 & 147.9 & 87.6 & $2,644.7$ \\
\hline
\end{tabular}

Source: Projected uranium requirements calculated using the International Nuclear Model, based on capacity projecinns from Energy Information Administration, Commercial Nuclear Power 1990: Prospects for the United States and the World, DOE/EIA-0438(90) (Washington, DC, September 1990). 
Figure 8. Average Annual Uranium Rezuirements for the Free Market Economies, 1990-2010

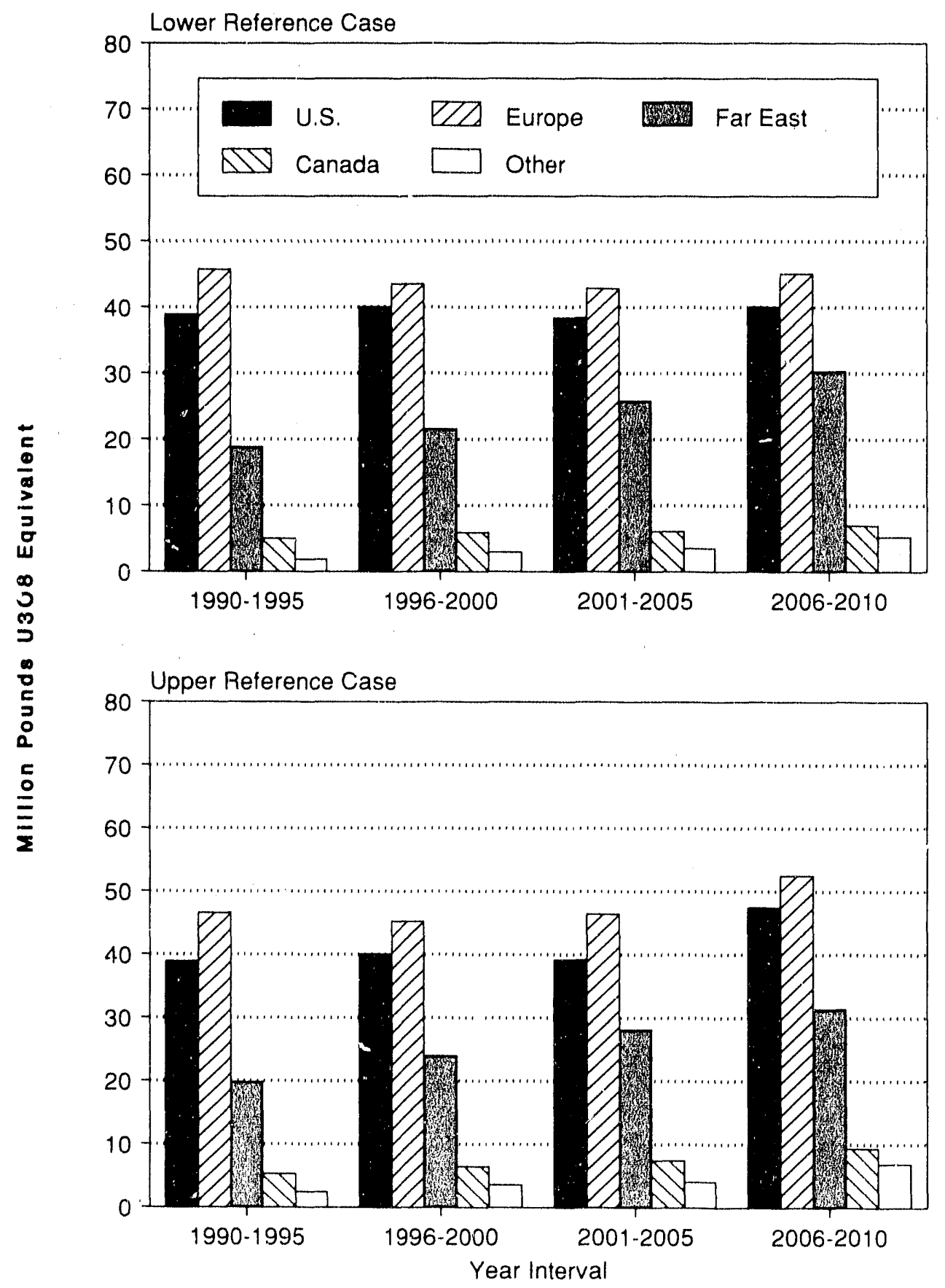

Note: Uranium requirements calculated using the Internationtid Nuclear Model. Source: See Appendix E. 
Figure 9. Cumulative Uranium Requirements for the Free Market Economies, 1990-2010

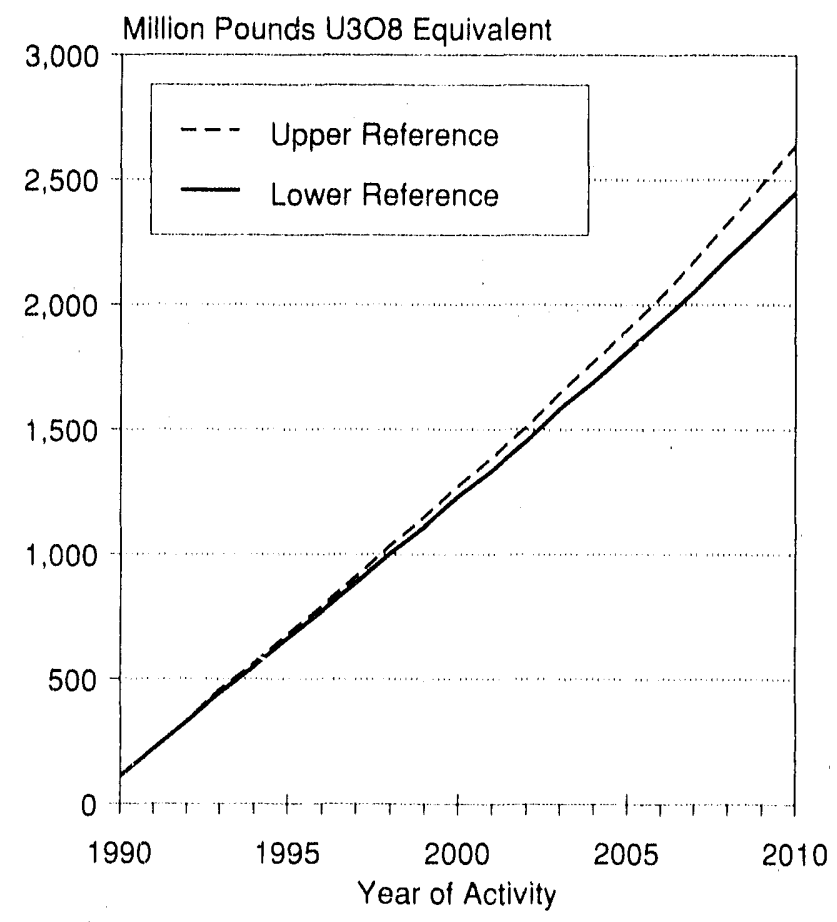

Note: Uranium requirements calculated using the International Nuclear Model.

Source: See Appendix E.

\section{Uranium Enrichment Service Requirements}

Average annual FME requirements for uranium enrichment services (SWU requirements) are projected to grow in the Upper Reference case from 27.7 million SWU in 1990 through 1995 to 38.3 million SWU in the years 2006-2010, an increase of 38 percent (Table 12 and Figure 10). The enrichment service requirements for the "other countries" group are expected to more than double over the same period. No enrichment service requirements are indicated for Canada, where only natural-uranium-fueled reactors are used. The U.S. Upper-Reference-case share of annual FME enrichment service requirements is projected to range between 29 and 33 percent through the forecast period. The European share of the annual einrichment service requirements is 49 percent of the average FME requirements for the Upper Reference case in the 1990 through 1995 period, and declines to about 43 percent in 2006 through 2010 .

Current worldwide enrichment capacity (38.6 million separative work units in Table 13) is ample to meet the near-term demand for enriched uranium. Moreover, it appears that current capacity can also meet the demand through 2010. A modest increase in capacity is shown by 1995 , going from 38.6 to 39.8 million separative work units.

Table 12. Projected Average Annual Uranium Enrichment Service Requirements for Nuclear Power Plants in the Free Market Economies, 1990-2010

(Million Separative Work Units)

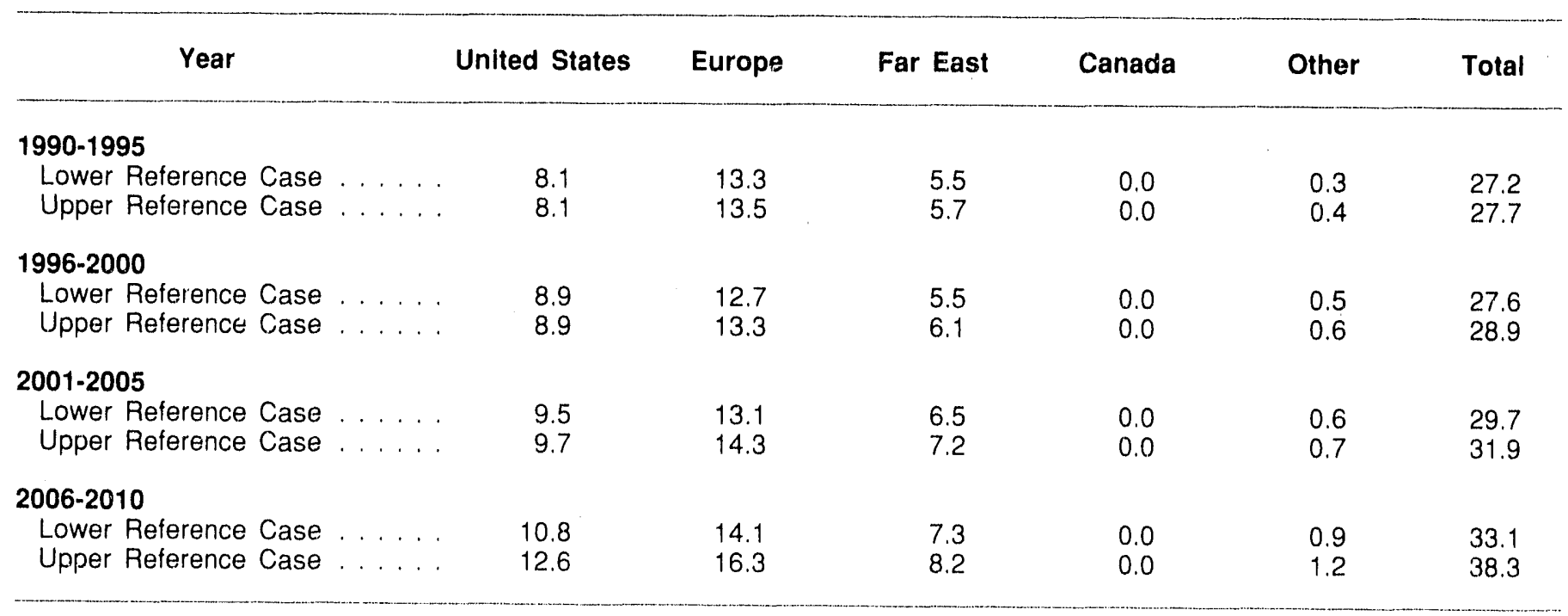

Source: Projected uranium requirements calculated using the International Nuclear Model, based on capacity projections from Energy Information Administration, Commercial Nuclear Power 1990: Prospects for the United States and the World, DOE/EIA-0438(90) (WashingtorI, DC, September 1990). 
Figure 10. Average Annual Uranium Enrichment Service Requirements for the Free Market Economies, 1990-2010

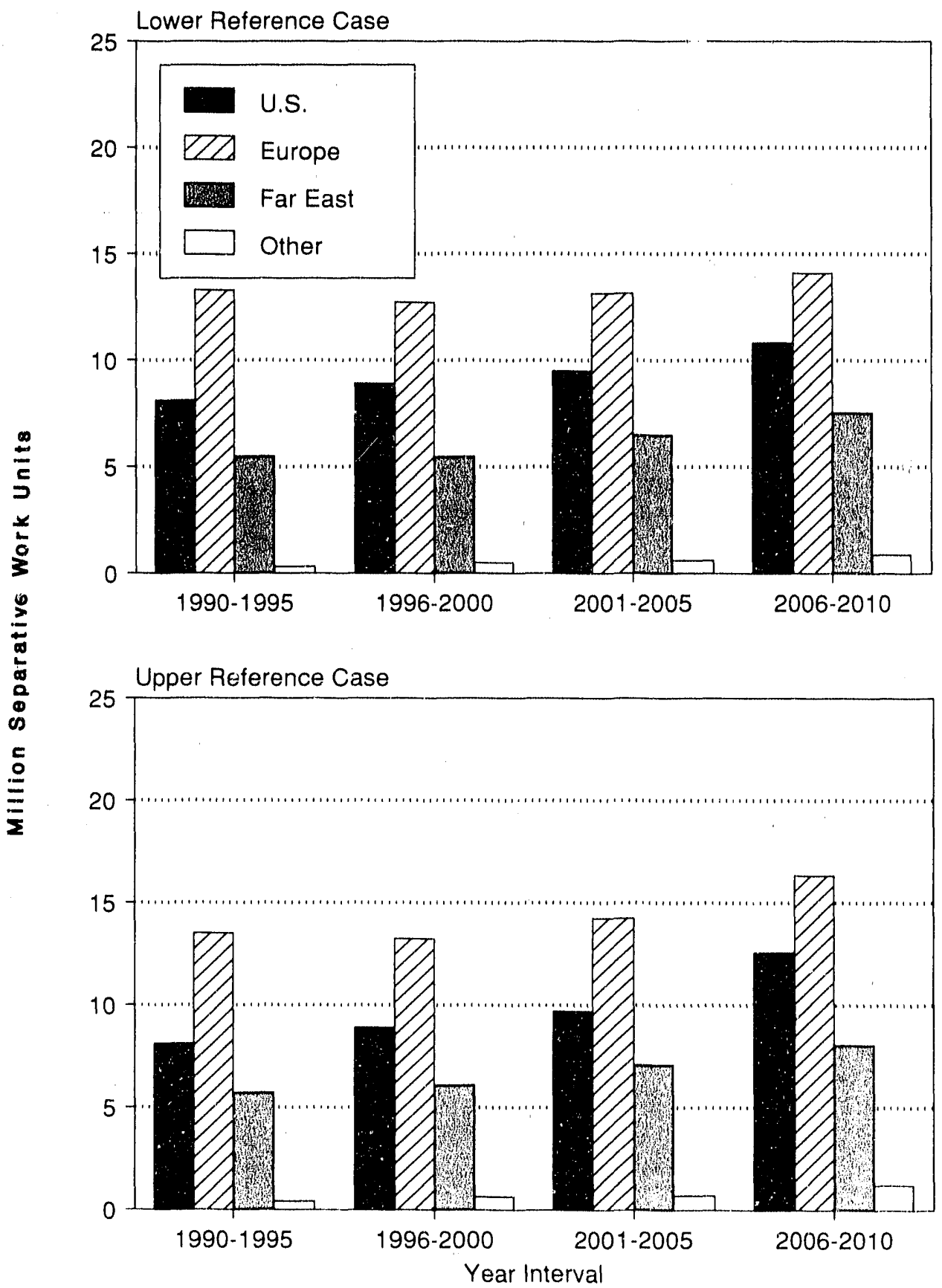

Note: Uranium requirements calculated using the International Nuclear Model.

Source: See Appendix E. 
Table 13. Projected Nominal Capacity of World Uranium Enrichment Facilities at the End of the Year (Million Separative Work Units)

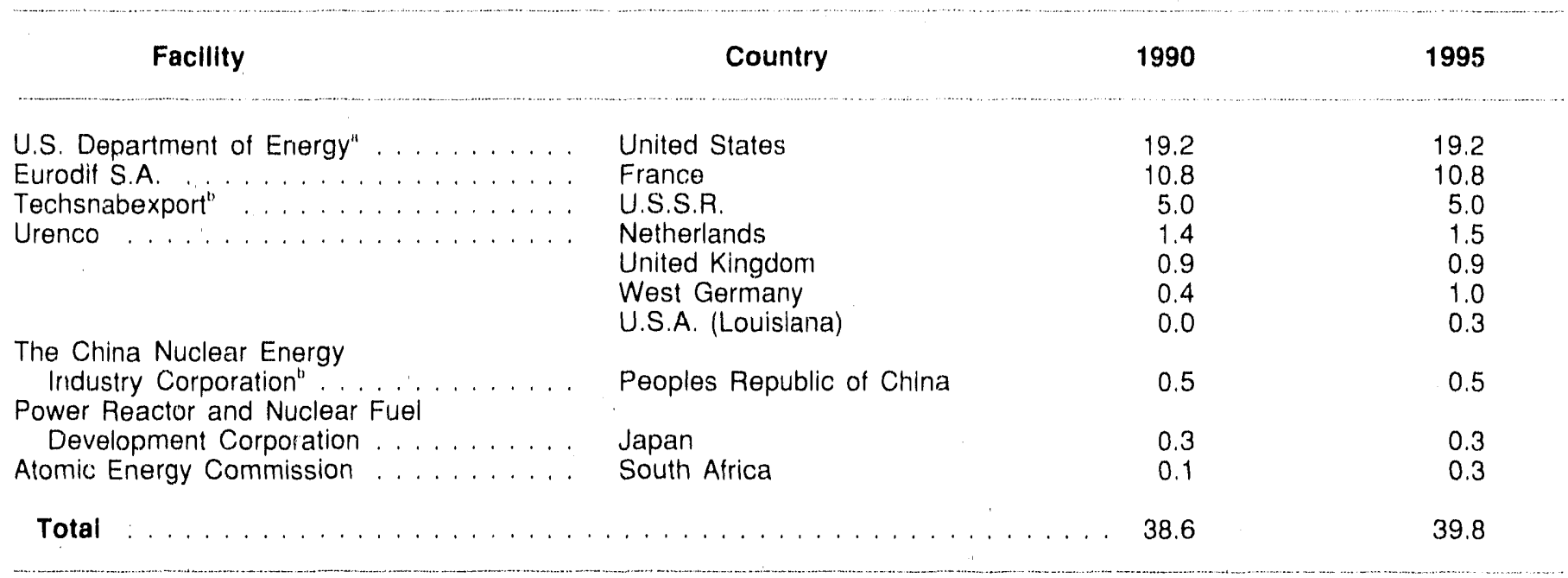

"U.S. Department of Energy, Office of the Assistant Secretary for Nuclear Energy

"Estimated availability to FME countries.

Source: Nuclear Assurance Corporation, Fuel Trac Status Report (Atlanta, GA, February 1990).

\section{Spent Fuel Discharges}

The data show that the average annual spent fuel discharges are relatively stable over the projection period, averaging about 9.7 million pounds through the forecast period for the Lower Reference case (Table 14 and Figure 11).
Cumulative spent fuel discharges for FME countries: in 1990 through 2010 are shown in Table 15. For the Lower Reference case, 202.6 thousand MTIHIM are projected to be discharged from nuclear reactors between 1990 and 2010. Almost 40 percent of that amount will be from European reactors, 23 percent from Canadian reactors, and 19 percent from U.S. reactors.

Table 14. Projected Average Anriual Discharges of Spent Fuel from Nuclear Power Plants in the Free Market Economies, 1990-2010

(Thousand Metric Tons of Initial Heavy Metal)

\begin{tabular}{|c|c|c|c|c|c|c|}
\hline Year & United States & Europe & Far East & Canada & Other & Total \\
\hline \multicolumn{7}{|l|}{$1990-1995$} \\
\hline Lower Reference Case & 2.0 & 4.8 & 1.3 & 1.8 & 0.3 & 10.1 \\
\hline Upper Reference Case & 2.0 & 4.8 & 1.3 & 1.9 & 0.3 & 10.3 \\
\hline \multicolumn{7}{|l|}{$1996-2000$} \\
\hline Lower Reference Case & 1.8 & 3.7 & 1.2 & 2.1 & 0.3 & 9.1 \\
\hline Upper Reference Case & 1.8 & 3.8 & 1.3 & 2.2 & 0.5 & 9.6 \\
\hline \multicolumn{7}{|l|}{ 2001-2005 } \\
\hline Lower Reference Case & 1.8 & 3.6 & 1.3 & 2.2 & 0.5 & 9.5 \\
\hline Upper Reference Case & 1.8 & 3.8 & 1.5 & 2.7 & 0.6 & 10.4 \\
\hline \multicolumn{7}{|l|}{ 2006-2010 } \\
\hline Lower Reference Case & 1.9 & 3.4 & 1.6 & 2.7 & 0.6 & 10.2 \\
\hline Upper Reference Case & 1.9 & 3.6 & 1.7 & 3.3 & 0.7 & 11.2 \\
\hline
\end{tabular}

Note: Totals may not equal sum of components due to independent rounding.

Source: Projected uranium requirements calculated using the International Nuclear Model, based on capacity projections from Energy Information Administration, Commercial Nuclear Power 1990: Prospects for the United States and the World, DOE/EIA-0438(90) (Washington, DC, September 1990). 
Figure 11. Average Annual Nuclear Spent Fuel Discharges for the Fre? Market Economies, 1990-2010

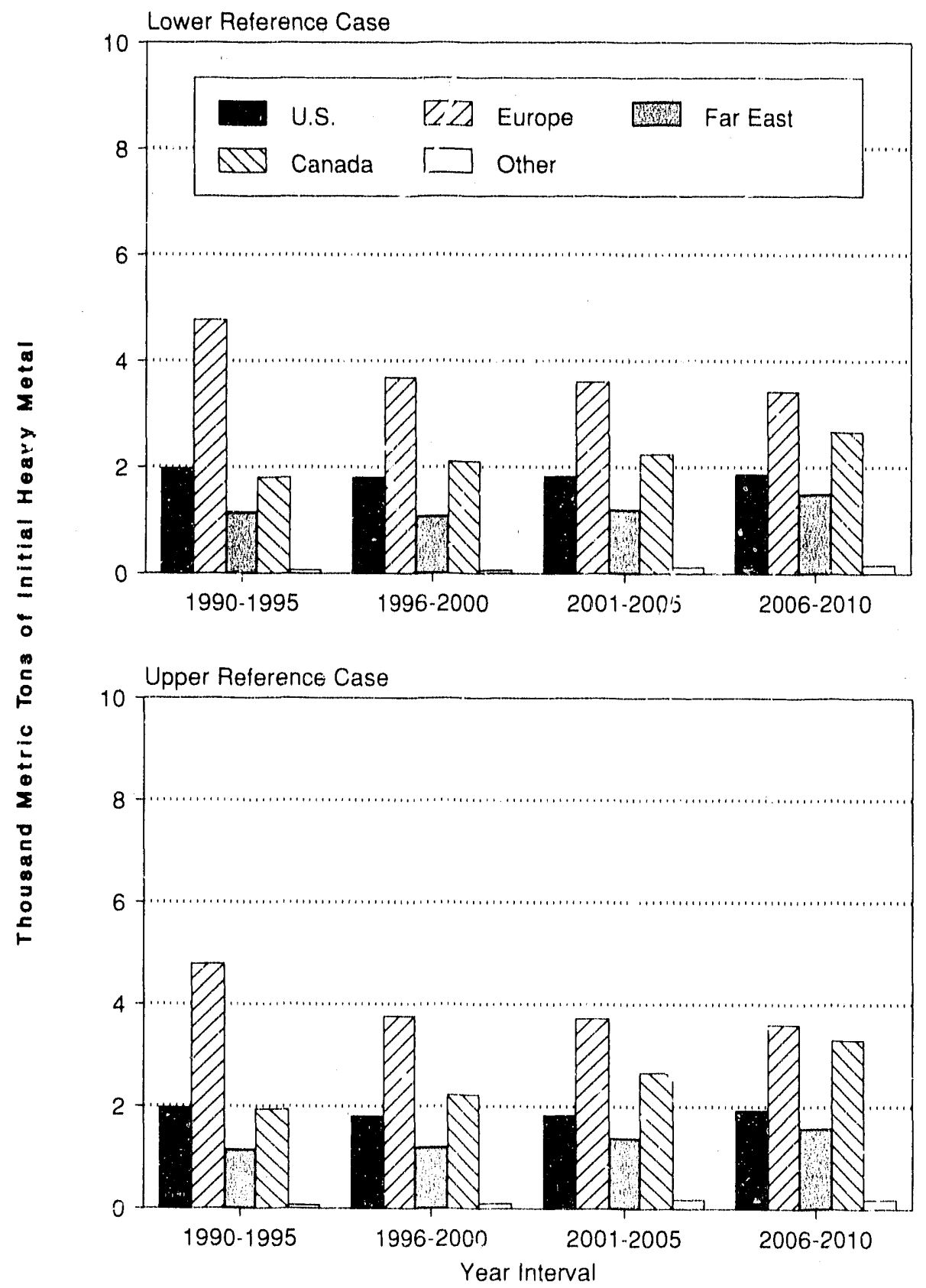

Note: Uranium requirements calculated using the International Nuclear Model.

Source: See Appendix E. 
Table 15. Projected Cumulative Discharges of Spent Fuel from Nuclear Power Plants in the Free Market Economies, 1990-2010

(Thousand Metric Tons of Initial Heavy Metal)

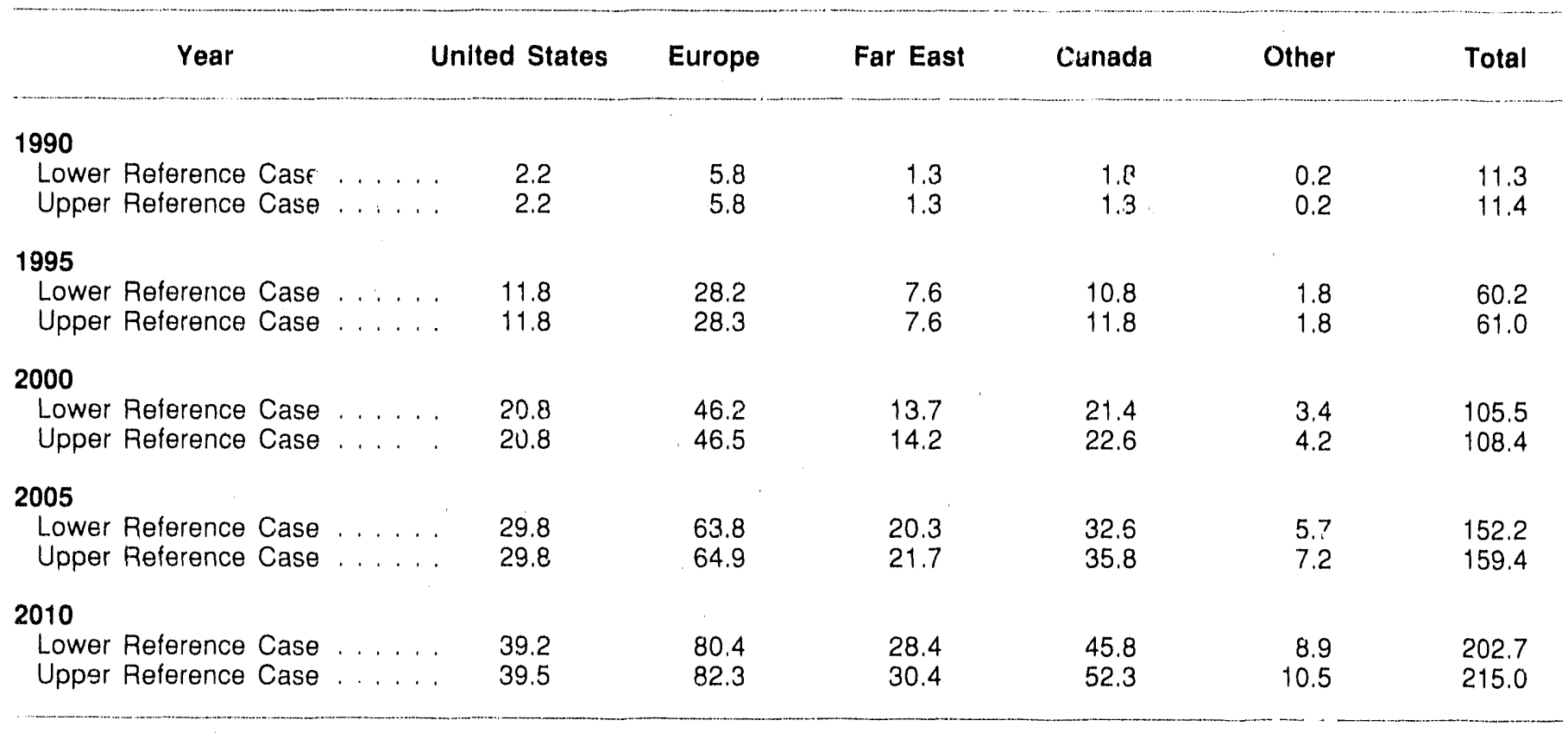

Note: Discharges of spent fuel are cumulative from 1990.

Source: Projected uranium requirements calculated using the International Nuclear Model, based on capacity projections from Energy Information Administration, Commercial Nuclear Power 1990: Prospects for the United States and the World, DOE/EIA-0438(90) (Washington, DC, September 1990).

\section{Mixed Oxide Fuel Use}

This section of the report briefly examines the iffect of mixed oxide fuel (MOX) use on the lower Reference Base case for Europe. MOX fuel refers to a mixture of reactor grade plutonium and either natural or depleted uranium to replace a fraction of the partially enriched uranium. As mentioned earlier in the report, no use of recycled uranium was assumed for the base case and that assumption applies here as well. The sensitivity assumes that MOX fuel will be used by 28 reactors in France, Germany and Switzerland starting in 1990), with a gradual phase in for use by all 28 reactors by the late 1990's. These 28 reactors have all been licensed for use of MOX fuel and have either already loaded MOX fuel in Germany and Switzerland or have been positively identified for MOX fuel reload by the large French utility, EDF.

Table 16 displays the fuel cycle statistics with and without MOX fuel diets. Average annual requirements decrease by 6.5 percent in 1990)-1995 and 3.9 in 2006 through 2010 . Tetal uranium requirements decrease by 9.3 percent in 1990, dropping to 5.8 percent in 20000, and to a 5 percent decrease in 2010, the last year of the projection period. The reason that the affect of MOX fuel use on total uranium requirements is declining over the projection period is because some of the re ators using MOX fuel diets are retired through the projection period, and their replacements were assumed to use only uranium oxide fuel. MOX fuel dicts decrease annual enrichment services by 8.2 percent in 199()-1995 and by 4.6 percent in the years $20(66-2010$. 
Table 16. Sensitivity of Lower-Reference-Case Projections of European Nuclear Fuel Cycle Requirements to Mixed-Oxide Fuel Use Assumption, 1990-2010

$\begin{array}{llll}\text { Projection Without MOX Fuel With MOX Fuel Percent Difference } & \text { W }\end{array}$

Average Annual Natural Uranium Requirements (million pounds $U_{3} \mathrm{O}_{3}$ equivalent)

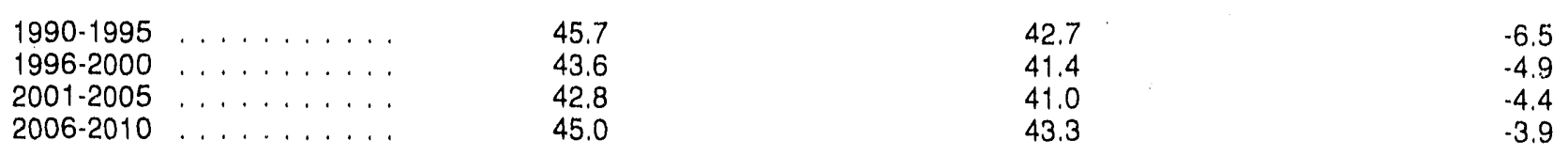

Total Natural Uranium Requirements (million pounds $U_{3} O_{8}$ equivalent)

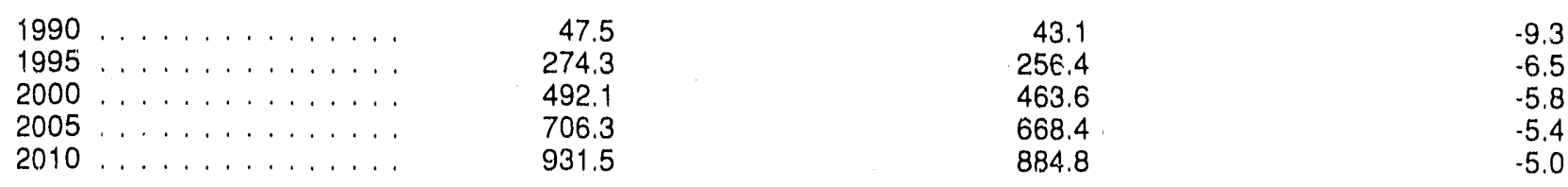

Average Annual Uranium Enrichment Service Requirements (million separative work units)

\begin{tabular}{|c|c|c|c|}
\hline $\begin{array}{l}1990-1995 \\
1996-2000 \\
2001-2005 \\
2006-2010\end{array}$ & $\begin{array}{l}13.3 \\
12.7 \\
13.1 \\
14.1\end{array}$ & $\begin{array}{l}12.2 \\
12.0 \\
12.4\end{array}$ & $\begin{array}{l}-8.2 \\
-5.4 \\
-5.6 \\
-4.6\end{array}$ \\
\hline
\end{tabular}

Source: Projected fuel cycle requirements calculated using the International Nuclear Model, based on capacity projections from Energy Information Administration, Commercial Nuclear Power 1990: Prospects for the United States and the World, DOE/EIA-0438(90) (Washington, DC, September 1990). 


\section{Comparison with Other Forecasts}

This chapter compare's the projections of the fuel cycle requirements for the Energy Information Administration's 1990 Upper Reference Case vith those of other forcasts, mamely: (1) the projections for ElA's 1989 Upper Reference Case which were reported in last year's edition of this report," (2) Fuel-Trae reports from the Nuclear Assurance Corporation (NAC)," (.3) a market analysis by Energy Resources International," (4) a market analysis by Nuexco," and (5) Data Systems reports from NUKEM." The comparisons are based on total requirements for 1990) through 1495, and for 1946 through 2000). The EIA Upper Reference case wiss used for this comparison because its assumptions are closer to the gencrally optimistic outlook projected by the other forecasts, especially in the 1996 through 2000 time frame. Projected fuel cycle requirements are compared for the United States (Table: 17) and for the FME countries (Table 18).

\section{Comparison with Last Year's EIA Report}

The cumulative U.S. uranium requirements from 1990) through 2000$)$ projected in this report are 3.8 percent higher than those projected in last year's Upper Reference Case, and the cumulative enrichment service requirements thro'igh 2000 are 7 percent lower than projected last year (Table 17). The higher estimates of uranium requirements and the lower estimates of enrichment requirements are explained by higher enrichment transaction tails assays than were assumed for last year's Upper Reference case. The projections of U.S. spent fuel discharges are 1.4 percent less than reported in 1989, due to slight increases in burnup and slight decreases in projected electrical generation.

Table 19 is a comparison of the actual versus the projected values of U.S. spent fuel discharges for each of the years in the 5-year period in which the EIA has used the International Nuclear Model (INM) to make nuclear fuel cycle projections. The comparisons are between the published projections and the following year's survey results. The absolute values of the differences between the projected and actual spent fuel discharges range from 3 pereent to a high of 18 perceni. For all years combined, the difference is less than 1 percent.

\section{Comparison With Other Reports}

The basic process for modeling nuclear fuel cycle requirements is essentially the same for all forecasters. The major differences among the various forecasts are due to differing perceptions of current conditions and different combinations of exogenous assumptions regarding capacity factors, tails assays, fresh fuel assays, and burnup. The comparison of input data and assumptions is much more important than the comparison of projected numerical fuel cycle requirements among the different reports. Unfortunately, complete listings of the controlling assumptions generally are not presented with the projected numerical values.

EIA's projections of fuel cycle requirements are reactor requirements only and, as such, are independent of considerations of inventories of natural uranium and separative work. Moreover, they do not take into account existing contracts for future requirements. EIA presents its market analyses in its uranium industry viability assessment."

For U.S. fuel cycle requirements, the EIA projections are comparatively low with respect to some of the other forecasts. For cumulative U.S. uranium requirements from 1990) through 2000$)$, the differences range between 0.2 percent lower and 13.6 percent higher, and for enrichment requirements the other forecasts are from 3.2 to $28 .()$ percent higher than the EIA projections.

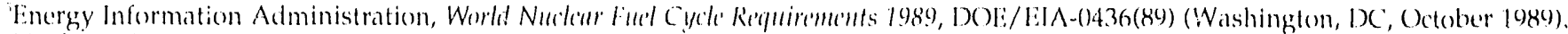
"Nuclear Assurance Corporation, Finl-Trie Reports: "U, $O_{k}$ Status Report"; "Rinridhment Status Report"; and "Discharge Fuel/Reprocessing Roport" (Atlinta, CiA, August 1990)).

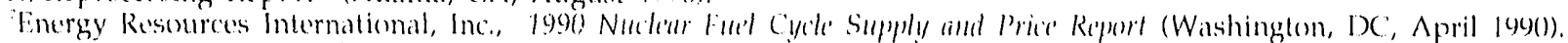

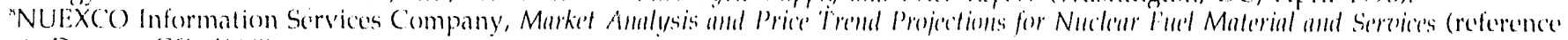
casc) (Denver, $C O, 199(1)$.

"NUKEM, Ins., N!IKIIM Data Systems (Stamiord, CT, Junc 199()).

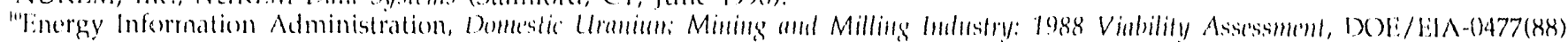
(Washingtom, DC, December 1989).
} 
Table 17. Comparison of Selected Forecasts of U.S. Fuel Cycle Requirements

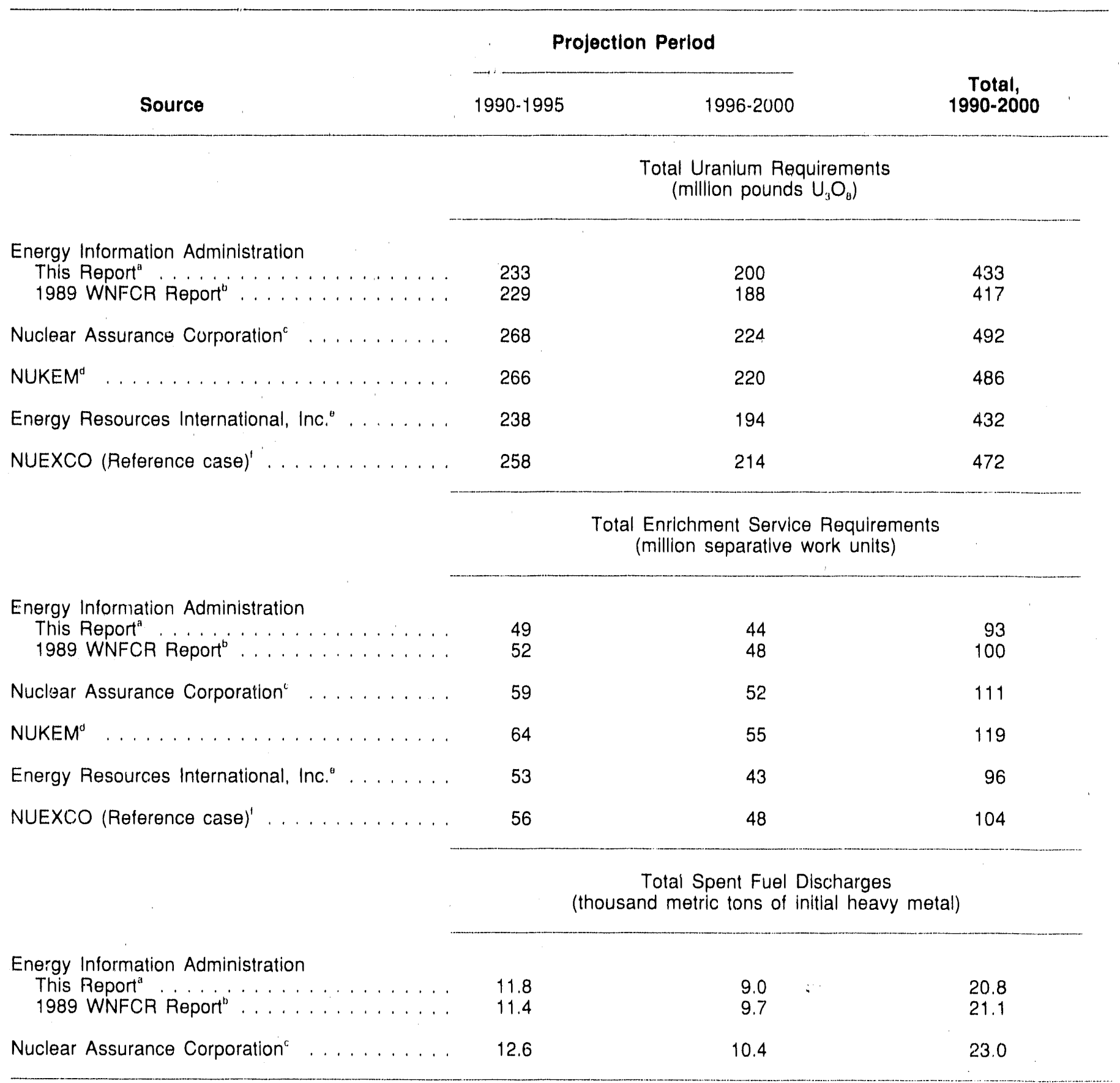

Note: Differences in this year's projections made by the Energy Information Administration from last year's report are due to changes in assumptions about installed capacity and iuel cycle operating parameters.

Sources:

"Energy Information Administration, 1990 Upper-Reference-case projections.

"Energy Information Administration. World Nuclear Fuel Cycle Requirements 1989, DOE/EIA-0436(89) (Washington, DC, October 1989). Upper-Reference-case projections.

"Nuclear Assurance Corporation, Fuel-Trac Reports: " $\mathrm{U}_{3} \mathrm{O}_{8}$ Status Report"; "Enrichment Status Report"; and "Discharge Fuel/Reprocessing Report" (Atlanta, GA, August 1990).

"NUKEM, Inc., NUKEM Data Systems (Stamford, CT, June 1990). 1990)

"Energy Resources International, Inc., 1990 Nuclear Fuel Cycle Supply and Price Report (mid range) (Washington, DC, April

'NUEXCO Information Services Company, Market Analysis and Price Trend Projections for Nuclear Fuel Material and Services (reference case) (Denver, CO, 1990). 
Table 18. Comparison of Selected Forecasts of Fuel Cycle Requirements for the Free Market Economies

\begin{tabular}{|c|c|c|c|}
\hline \multirow[b]{2}{*}{ Source } & \multicolumn{2}{|c|}{ Projection Period } & \multirow[b]{2}{*}{$\begin{array}{l}\text { Total, } \\
1990-2000\end{array}$} \\
\hline & $1990-1995$ & $1996-2000$ & \\
\hline & \multicolumn{3}{|c|}{$\begin{array}{l}\text { Total Uranium Requirements } \\
\text { (million pounds } \cup_{3} \mathrm{O}_{3} \text { ) }\end{array}$} \\
\hline \multicolumn{3}{|l|}{ Energy Information Administration } & 1,275 \\
\hline Nuclear Assurance Corporation ${ }^{\prime} \ldots \ldots \ldots$ & 767 & 678 & 1,445 \\
\hline NUKEM ${ }^{\circ} \ldots \ldots \ldots \ldots \ldots \ldots \ldots \ldots \ldots$ & 770 & 690 & 1,460 \\
\hline Energy Resources International, Inc. ${ }^{d} \ldots \ldots \ldots$ & 669 & 616 & 1,285 \\
\hline \multirow[t]{2}{*}{ NUEXCO (Reference Case)" } & 766 & 684 & 1,450 \\
\hline & \multicolumn{3}{|c|}{$\begin{array}{l}\text { Total Enrichment Service Fequirements } \\
\text { (million separative work units) }\end{array}$} \\
\hline \multicolumn{4}{|l|}{ Energy Information Administration } \\
\hline This Report" . . . . . . . . . . . . . . . . . & 166 & 145 & 311 \\
\hline Nuclear Assurance Corporation ${ }^{n} \ldots \ldots \ldots$ & 168 & 154 & 322 \\
\hline NUKEM $^{c} \ldots \ldots \ldots \ldots \ldots \ldots \ldots \ldots$ & 174 & 159 & 333 \\
\hline Energy Resources International, Inc. ${ }^{d} \ldots \ldots \ldots$ & 135 & 123 & 258 \\
\hline \multirow[t]{2}{*}{ NUEXCO (Reference Case)" } & 148 & 137 & 285 \\
\hline & \multicolumn{3}{|c|}{$\begin{array}{l}\text { Total Spent Fuel Discharges } \\
\text { (thousand metric tons of Initlal heavy metal) }\end{array}$} \\
\hline \multicolumn{4}{|l|}{ Energy Information Administration } \\
\hline 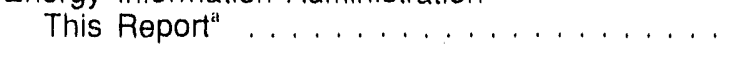 & 62 & 48 & 110 \\
\hline Nuclear Assurance Corporation ${ }^{\mathrm{b}} \ldots \ldots \ldots \ldots$ & 57 & 48 & 105 \\
\hline
\end{tabular}

Note: Differences in this years projections made by the Energy Information Administra'ion from last years report are due to changes in assur? ntions about installed capaclty, and fuel cycle operating parameters.

Sources:

"Energy Information Administration, 1990 Upper-Reference-case projections.

"Nuclear Assurance Corporation, Fuel-Trac Reports: " $\mathrm{U}_{3} \mathrm{O}_{0}$ Status Report"; "Enrichment Status Report"; and "Discharge Fuel/Reprocessing Report" (Atlanta, GA, August 1990).

'NUKEM, Inc., NUKEM Data Systems (Stamford, CT, June 1990).

"Energy Resources International, Inc. 1990 Nuclear Fuel Cycle Supply and Price Report (mid range) (Washington, DC, April 1990).

${ }^{\theta}$ NUEXCO Information Services Company, Market Analysis and Price Trend Projections for Nuclear Fuel Material and Services (reference case) (Denver, CO, 1990). 
Table 19. Comparison of Actual U.S. Spent Fuel Discharges With Projections From This Annual Report

(Metric Tons of Inltlal Heavy Metal)

\begin{tabular}{|c|c|c|c|}
\hline Year & Actual" & Projected" & Difference \\
\hline $\begin{array}{l}1989 \ldots \\
1988 \ldots \\
1987 \ldots \\
1986 \\
1985 \ldots\end{array}$ & $\begin{array}{l}1,998.3 \\
1,698.5 \\
1,861.6 \\
1,481.4 \\
1,343.5\end{array}$ & $\begin{array}{l}2,053 \\
2,000 \\
1,600 \\
1,400 \\
1,299\end{array}$ & $\begin{array}{r}3 \% \\
18 \% \\
-14 \% \\
-5 \% \\
-3 \%\end{array}$ \\
\hline $1985-1989$ & $8,383.3$ & 8,352 & $\left({ }^{*}\right)$ \\
\hline
\end{tabular}

"Less than 1 percent.

"Source: Energy Information Administration, Form RW-859, "Nuclear Fuel Data" (1989).

"Source: Projected uranium requirements calculated using the International Nuclear Model, base'd on capacity projections from Energy Information Administration, Commercial Nuclear Power 1990: Prospects for the United States and the World, DOE/EIA-0438(90) (Washington, DC, September 1990).

'The percentages relate the differences between the projections for the year in which the report was published and the numbers obtained in the RW-859 survey.

For FME fuel cycle reguirements, the EIA projections are also low by comparison with the other forecasts, but are by no means the lowest (Table 18). For FME uronium requirements, the cumulative differences through the year 20)(0) range between 0.8 and 14.5 percent higher than the EIA projections. For FME enrichment requirements, the cumulative differences range between 3.5 percent higher and 17.0 percent lower. The reason that two of the other projections of FME requirements are lower than EIA's is the lower transactions tails assay (0.25 percent versus (0.30) percent U-235) assumed by the ELA.

In this respect, differences in projections of nuclear generating capacities and capacity factors, as well as differences in assumptions of fuel management variables, such as cycle length, refueling (batch) fraction, fuel enrichment levels, and burnup, have an impact on the amount of fuel required to generate a given amount of electricity, and will affect the projected fuel requirements. The enrichment tails assays under which the nuclear fuel is produced also affect the balance between uranium and enrichment reguirements.

As with the three basic EIA scenarios, the projections of installed nuclear capacity are generally similar among the forecasts through the late 199()'s. However, differences in projected capacity factors affect the projections of electricity generation, which in turn affect projected fuel cycle requirements. The
EIA generally projects lower capacity factors; thus, the EIA projections are generally lower than the other forecasts. In addition, the EIA perceives generally higher and increasing levels of fuel burnup, as opposed to the other forecasts, which typically assume lower burnup levels. The differences in the burnup projections, logether with the changes implied for the other fuel mamagement vartables that are physically and economically dependent on fuel burnup, further acount for the differences between forecasts.

\section{Nuclear Assurance Corporation (NAC) Fuel-Trac Status Reports}

Most of the differences between the EIA Upper Reference case and the NAC projections are caused by NAC's assumption of significantly higher operating capacity factors and lower initial and constant burnup levels, which, as explained above, combine to produce higher projected consumption of both natural uranium and enrichment services and higher discharge's of spent fuel. The following comparisons apply to the 1990)-20(0) timeframe: For the United States, the NAC projections of uranium, enrichment, and spent fuel are, respectively, 13.6, 19.4, and 10.6 percent higher than the ElA projections. For the FME nations, NAC's projections of uranium and enrichment requirements are 13.3 and 3.5 percent higher than EIA's, but the projection of spent fuel is 4.5 percent lower than EIA's.

\section{Energy Resources International Report}

The Mid Range Projection of the Energy Resources International (ERI) report is very clese to the EIA projections with regard to U.S. nuclear generating capacity. The ERI forecast was based on a higher transaction tails assay projection than that used by EIA. The burnup assumptions for different reactor types were not directly specified, but significant improvements in uranium and enrichment utilization efficiency were projected. For the 1990)-2000) timeframe, EIA's projected U.S. reactor requirements are 0.2 percent higher for uranium and 3.2 percent lower for enrichment services than the ERI projections.

ERI's projections for the FME nations were 0.8 percent higher for uranium and 17.0 percent lower for enrichment than EIA's projections for 199()-2000). The higher overall fuel cycle requirements (uranium plus enrichment) are attributable to slightly higher projections of installed nuclear capacity and somewhat higher capacity factor assumptions than projected by the ERI. The higher relitive difference between the projected enrichment requirements is explained by a significant difference in the tronsaction tails assavs assumed for foreign FME reactor requirements. 


\section{NUEXCO Report}

For the 199()-20)(0) timeframe, the Nuexer Reference Case assumptions produce significantly higher projections of U.S. uranium and enrichment reguirements than are derived from ElA's assimptions. The reactor fuel reguldrements (uranium plus enrichment) projected for the total liME are reasomably close to those projected by the EIA. However, because NUEXCO assumes a higher tails assay than EIA for foretgn FME nations, the projected reguirements for uranium are relitively higher for uranium and lower for enrichmont than projected by EIA. For the United States, NUEXCO's 1990(1-20)(0) projections are 9,() percent higher for uranium and 11.8 percent higher for enrichment repuirements. For the FME nations, the NUEXCO projections are 13.7 pereent higher for natural uranium and 8.4 pereent lower for enrichment than EIA's projections.

\section{NUKEM Data Systems Reports}

For the Uniled Stales, the NUKEM profections are 12.2 percent higher than biA's projections for uranium requirements and $28 .()$ pereent higher for enrichment service requirements. For the liME nations, the NUKEM projections are 14.5 percent higher for natural uranium requirements and 7.1 percent higher for enrichment service reguirements than the biA projections for the 1990)-200() period. It can be shown, however, with the impacts profected in the sensittivity cases, that the significant differences in the anderlying assumptions account for the differences between the two sets of forceists. The capacity factors projected by NUKEM are significantly higher than those assumed by I:IA, and this is the major catuse of the differences in projected fuel requirements. Also, LiA assimmess that nuclear fuel burnup levels will increase significantly in the future, whereas NUKEM projects constant fuel management plans for I'WR's and BWR's operating beyond their third refueling cycles. The resulting differences in fuel utilizatton efficienciesi contribute to the differences between the two projections. 
Appendix A

Nuclear Power Techriology and the Nuclear Fuel Cycle 


\section{Appendix A \\ Nuclear Power Technology and the Nuclear Fuel Cycle}

\section{Nuclear Fission}

When the feasibility of the nuclear fission reaction was confirmed in 1939, scientists recognized that tremendous amounts of energy could be released by this process. Although early attempts to harness this energy were directed to military purposes, tine harnessing of nuclear fission to produce electricity eventually became a commercial technology.

The nuclear fission process is one in which a heavy atomic nucleus (such as uranium) reacts with a free neutron." Most of the time this "reaction" is one in which the uranium nucleus splits (or "fissions") into two smaller nuclei, concurrently releasing energy and two or three additional free neutrons. Because more neutrons are released from a fission event than are needed to induce the event, a "chair rraction" can be sustained.

Of course, to be useful for commercial purposes, the rate of the chain reaction must be controlled. This is not as difficult as it might seem because nearly every other nucleus besides uranium reacts with free neutrons, usually by absorbing the neutron rather than by fissioning. Thus, a fission chain reaction is controlled by diluting the fissionable uranium atoms with other nonfissionable atoms.

Uranium in nature consists primarily of two "isotopes"-atoms with the same number of protons in the nucleus but different numbers of neutrons. One isotope is designated uranium-235 (or U-235); the other is uranium-238 (U-238). The numbers refer to the atomic mass, which is the sum of the number of protons and neutrons in the nucleus.

U-235 makes up only 0.7 percent of naturally occurring uranium; U-238 makes up almost all of the other 99.3 percent. U-235 nearly always reacts with a free neutron (that is, one outside the nucleus) by fissioning; thus, U-235 is called a "fissile" isotope. On the other hand, U-238 nearly always reacts with a free neutron by absorbing it rather than by fissioning. This absorption forms the isotope U-2.39, which in turn undergoes radioactive decay and eventually becomes Pu-239, an isotope of the element plutonium. Pu-239, like U-235, is a fissile isotope. U-238 is referred to as a "fertile" isotope, because it eventually produces the fissile Pu-239 isotope.

The vast majority of the world's nuclear power plant; operate by passing ordinary (that is, "light") water through a nuclear reactor in which uranium fuel, housed in an array of "fucl assemblies," undergoes a controlled chain reaction. The heat produced by nuclear fission events in the reactor core is carried away by the water, either as steam in a "boilingwater reactor" or as superheated water in a "pressurized-water reactor." In a pressurized-water reactor, a device called a "steam generator" transfers the heat from water in the primary loop (which has passed through the reactor core) to water in a secondary loop, which is turned into steam. Steam produced in either a boiling-water reactor or a pressurized-water reactor then passes to an electrical turbine-generator, which actually produces the electricity. Boiling-water reactors and pressurizedwater reactors are collectively called "light-water reactors." Other reactor designs have also been developed, such as the gas-cooled reactor, advanced gas-cooled reactor, and pressurized heavy-water reactor; these are used for commercial power generation in a number of foreign countries.

Because the coolant (water) in light-water reactors absorbs free neutrons, the concentration of fissile U-2.35 in uranium fuel must be increased over the concentration of 0.7 percent found in natural uranium in order for light-water reactors to sustain a nuclear

\footnotetext{
"Atomic nuclei consist of combinations of two types of subatomic particles, protons and neutrons, of about equal mass. The number of electrically charged protons in a nucleus determines which element it is- that is, its chemical properties. The number of protons plus the number of electrically neutral neutrons determines the weight or "atomic mass" of the nucleus. A "free neutron" is one that has been released frum an atomic nucleus.
} 
chain reaction. The process of uranium enrichment, as discussed below, is used to increase the concentration of $\mathrm{U}-235$ in the nuclear fuel used in light-water reactors to about 3 percent.

Before the initial startup of a nuclear power reactor, the core is loaded with fresh nuclear fuel. This fuel can be thought of as a reservoir from which energy is extracted as long as a chain reaction can be sustained. During the operation of the reactor, the concentration of U-235 decreases as U-235 nuclei fission to produce energy. In addition, fertile U-238 nuclei are constantly being converted into fissile Pu-239 nuclei, some of which will, in turn, fission and produce energy. While these reactions are going on, the concentration of neutron-absorbing fission products (also called "poisons") increases within the nuclear fuel assemblies. When the declining concentration of fissile nuclei and the increasing concentration of poisons reach the point at which a chain reaction can no longer be sustained (that is, when free neutrons are absorbed at a rate greater than the rate of fission events), the reactor must be shut down and refueled.

The amount of energy in the "reservoir" of nuclear fuel is frequently expressed in terms of "full-power days," which is the number of days the reactor could operate at full output before a fission chain reaction would cease to be sustained. If a reactor is not operated at full power, or if it is not operated at all times, the chronological operating period is increased correspondingly. The operating period varies inversely with the plant's "capacity factor," which is the ratio of its actual level of operation to the maximum, full-power level of operation for which it is designed.

As might be expected, the number of full-power days in a nuclear reactor's operating cycle (from one refueling to the next) is related to the amount of fissile U-235 contained in the fuel assemblies at the beginning of the cycle. The higher the percentage of U-235 at the initiation of a cycle, the greater the number of full-power days of operation in that cycle.

At the end of an operating cycle (when the chain reaction can no longer be sustained), some of the "spent" nuclear fuel is discharged and replaced with fresh fuel. The fraction of the reactor's fuel replaced at a refueling is called its "batch fraction"-typically, one-fourth for boiling-water reactors and one-third for pressurized-water reactors.

The amount of energy extracted from spent fuel is called its "burnup," expressed in terms of energy (heat) produced per initial fuel weight---such as, megawattdays thermal per metric ton of initial heavy metal.

\section{The Nuclear Fuel Cycle}

The nuclear fuel cycle for a typical light-water reactor is illustrated in Figure A1. The cycle consists of a "front end" that comprises the steps necessary to prepare nuclear fuel for reactor operation and a "back end" that comprises the steps necessary to manage the spent nuclear fuel, which is highly radioactive. It is technically possible to extract the unused uranium and plutonium from spent nuclear fuel through chemical reprocessing and to recycle the recovered uranium and plutonium as nuclear fuel. The front end of the cycle is divided into the following steps:

- Exploration. Ore bodies containing uranium are first located by drilling and other geological techniques. Known deposits of ore for which enough information is available to estimate the quantity and cost of production are called reserves. Ore deposits inferred to exist but as yet undiscovered are called potential resources.

- Mining. Uranium-bearing ore is mined by methods similar to those used for other metal ores. The uranium content of ores in the United States typically ranges from 0.05 to 0.3 percent uranium oxide $\left(\mathrm{U}_{3} \mathrm{O}_{8}\right)$. In foreign countries the uranium content of ores varies widely, from 0.035 percent in South West Africa to 2.5 percent in northern Saskatchewan, Canada. In general, foreign ores are of a higher grade than those mined in the United States. Commercially significant amounts of uranium are also obtained by methods other than conventional mining, such as solution mining, and as a byproduct of phosphate mining.

- Milling. At uranium mills, usually located near the mines, uranium-bearing ore is crushed and ground, and the uranium oxide is chemically extracted. The mill product, called uranium concentrate or "yellowcake," is then marketed and sold as pounds or short tons of $\mathrm{U}_{1} \mathrm{O}_{x}$.

- Conversion to $\mathbf{U F}_{t}$. Next, the $U_{3} \mathrm{O}_{x}$ is chemically converted to uranium hexafluoride $\left(U F_{1}\right)$, which is a solid at room temperature but changes to a gas at slightly higher temperatures. This is a necessary feature for the next step, enrichment.

- Enrichment. Natural uranium cannot be used as fuel in light-water reactors because its content of fissile U-235 is too low to sustain a nuclear chain reaction. The gaseous diffusion process currently used for uranium enrichment (that is, increasing its U-235 content) consists of passing a "feed stream" of UF, gas through a 


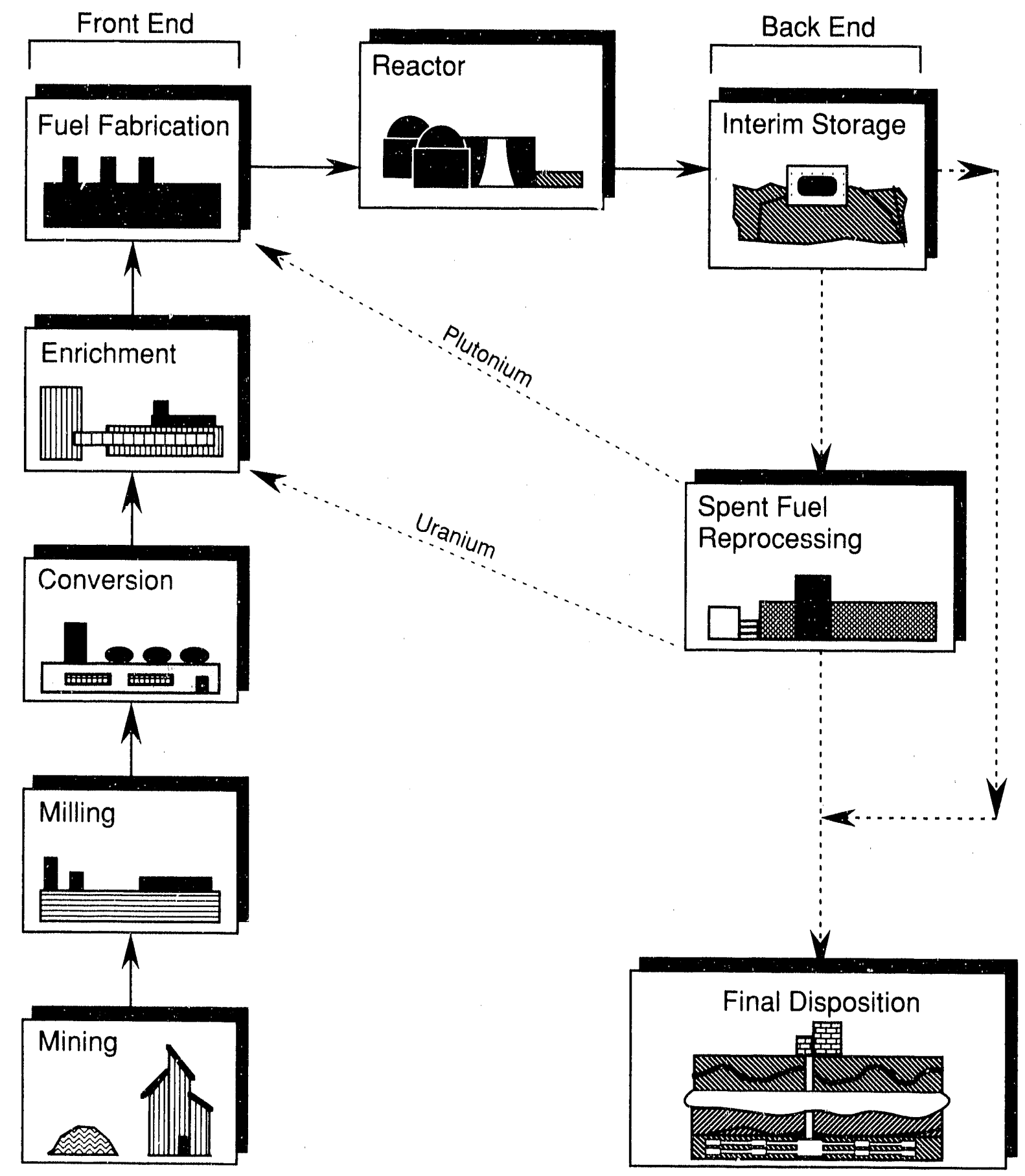

Fuel cycle as it currently operates in the United States.

......... Fuel cycle as it currently operates with spent fuel reprocessing in some Free Market Economies and/or final waste siorage. 
long series of diffusion barriers that pass U-235 at a faster rate than the heavier U-238 atoms. This differential treatment progressively increases the percentage of $U-235$ in the "product stream." The "waste stream" or "enrichment tails stream" contains the depleted uranium (that is, uranium having a U-235 concentration below the natural concentration of 0.7 percent). The U-235 concentration in the waste stream, called the "enrichment tails assay," is fixed by the operator of the enrichment facility. The gaseous diffusion enrichment process is extremely energy intensive. The work or energy expenditure required for uranium enrichment is measured in terms of separative work units.

A second enrichment technology, gas centrifuge separation, has been used commercially in the Netherlands. A domestic gas centrifuge separation plant was under construction but has now been canceled. A third enrichment technology, laser separation, is currently under development.

- Fabrication. The enriched $U_{6}$ is changed to an oxide and then into pellets of ceramic uranium dioxide $\left(\mathrm{UO}_{2}\right)$, which are then sealed into corrosion-resistant tubes of zirconium alloy or stainless steel. The loaded tubes, called elements or rods, are mounted into special assemblies for loading into the reactor.

The back end of the cycle is divided into the following steps:

- Interim Storage. After its operating cycle, the reactor is shut down for refueling. The fuel discharged at that time (spent fuel) is stored either at the reactor site or, potentially, in a common facility away from reactor sites. If on site pool storage capacity is exceeded, it may be desirable to store aged fuel in modular dry storage facilities at the reactor site or at a facility away from the site. The spent fuel rods are usually stored in water, which provides both cooling (the spent fuel continues to generate heat as a result of residual radioactive decay) and shielding (to protect the environment from residual ionizing radiation).

- Reprocessing. Spent fuel discharged from light-water reactors contains appreciable quantities of fissile (U-235, Pu-239), fertile (U-238), and other radioactive materials. These fissile and fertile materials can be chemically separated and recovered from the spent fuel. The recovered uranium and plutonium can, if economic and institutional conditions permit, be recycled for use as nuclear fuel.

- Waste Disposal. A current concern in the nuclear power field is the safe disposal and isolation of either spent fuel from reactors or, if the reprocessing option is used, wastes from reprocessing plants. These materials must be isolated from the biosphere until the radioactivity contained in them has diminished to a safe level. Under the Nuclear Waste Policy Act of 1982, as amended, the Department of Energy has responsibility for the development of the waste disposal system for spent nuclear fuel and high-level radioactive waste. Current plans call for the ultimate disposal of the wastes in solid form in licensed deep, stable geologic structures. 
Appendix B

Methodology and Assumed

Fuel Cycle Plans for

Increased Fuel Burnup 


\section{Appendix B \\ Methodology and Assumed Fuel Cycle Plans for
Increased Fuel Burnup}

The Model

The estimates of the nuclear fuel cycle requirements in this report were produced with the International Nuclear Model (INM). This model was developed under contract for the Nuclear and Alternate Fuels Division of the Office of Coal, Nuclear, Electric and Alternate Fuels in the Energy Information Administration (EIA). ${ }^{12}$ The INM is used to simulate nuclear fuel cycle operations.

The data for the INM include the following general categories:

- Operating Reactor Data. This is a list of information on nuclear reactors assumed to be operable during the time period being analyzed. For each reactor, the list includes the name, start and retirement dates, net summer capability, generic category to which the reactor is assigned, indicators of the fuel management plans to be used, and the applicable dates for the fuel management plans.

- Generic Reactor Data. Each operating reactor is classified into one of the generic categories, such as boiling-water reactor and pressurizedwater reactor. The data for the generic categories of reactors include capacity factors, thermal efficiency, maintenance priority, and a list of allowable fuel management plans.

- Fuel Management Data. The data describing a fuel management plan are used to simulate the internal workings of operating reactors. Fuel management data consist of the following: full power days, capacity factors, kilograms of enriched uranium per megawatt of capacity loaded during each refueling, spent fuel discharged, assays of the fissile isotopes in the fuel loaded and discharged, and fraction of core replaced.
- Fuel Cycle Parameters. These data items include lead and lag times from the start of a cycle for the fuel cycle processes (that is', conversion, enrichment, fabrication, spent fuel disposal), tails assays for enrichment services, ${ }^{13}$ process mass-loss factors, and process waste production.

- Control/Scenario Data. The user can specify data such as annual capacity factors for all equilibrium cycles.

Annual requirements for uranium concentrate $\left(\mathrm{U}_{3} \mathrm{O}_{\mathrm{k}}\right)$ and enrichment services, as well as discharges of spent fuel, are a function of the fuel management plan being used by each reactor, and the specified tails assay for enrichment services. To calculate the annual requirements, the date for the start of a cycle is determined for each reactor by a formula that uses (a) the number of full power days specified in the fuel management plan and (b) the capacity factor. (A "full-power day" is the equivalent of 24 hours of fullpower operation of a reactor.) The length of the cycle can then be determined as follows:

$$
\begin{aligned}
& \text { Length of cycle = } \\
& \text { (number of full-power days) / (capacity factor). }
\end{aligned}
$$

The length of the cycle includes the time during which electricity is being generated and the time during which the reactor is not operating (such as during refueling). The lead times for fuel cycle services must also be incorporated: $\mathrm{U}_{3} \mathrm{O}_{k}$ is delivered to a conversion plant 15 months before the restart of the nuclear unit, and enrichment services begin 12 months before the restart of the unit. Finaliy, the quantities of $\mathrm{U}_{3} \mathrm{O}_{4}$ and enrichment services required are determined from the amount of enriched uranium specified in the fuel management plan and from the enriched product assay and transaction tails assay. For a new reactor, the fuel management data and the lead times for the initial cycles are unique. After a

\footnotetext{
${ }_{12}^{12}$ David Andress, System Sciences Inc, Intermational Nuclear Model, Vols. I, II, and III (Bethesda, MD), 1985).

"Tails assay" refers to the concentration of the U-2.35 isotope in the waste stream fron the enrichment process. The higher the concentration of $U-235$ in the waste, the lower the requirement for enrichment service but the greater the reguirement for natural uranium for a given quantity of enriched uranium produced.
} 
reactor has reached eguilibrium, the full-power days in a cycle, the quantity of fuel loaded, and the spent fuel discharged per cycle remain constant for a specific fuel management plan.

The INM is used to produce annual summary reports for generic reactor categories and totals for all reactors. These reports include: ammal generation of clectricity, annual capacity factors, annual and cumbalative requirements for $\mathrm{U}_{3} \mathrm{O}_{\mathrm{H}}$ and enrichment services, anmual discharges of spent fuel, and total spent fuel discharges less the spent fuel withdrawn for reprocessing. The uranium concentrate requirements are reported as requirements for $U_{1} O_{B}$ or "yellowcake:"; the enrichment service requirements are measured in separative work units; and the discharges of spent fuel are expressed in metric tons of initial henvy metal. The projected discharges of spent fuel exclude discharged fuel that is designated for reinsertion.

\section{Nuclear Fuel Management Plans and Nuclear Fuel Burnup}

Fuel management plans for the generic reactor categories were developed from a statistical analysis of historical fuel cycle data. The historical data include the following: capacity, fuel inserted per cycle $\left(U, O_{k}\right.$, uranium metal, $\left.U-235\right)$, requirements for uranium enrichment service, cycle length, capacity factor, full-power days, spent fuel discharges, and fuel burnup.

Nuclear fuel burnup is a measure of the amount of energy produced from each metric ton of enriched uranium. The average burnup levels have been increasing and increases are expected to continue. For boiling-water reactors, the average equilibrium spent fuel discharge burnup in 1989 was approximately 27,000 MWDT/MTIHM. The burnup values ranged from under 20,000 to over $30,0(0)$ MWDT/MTIHM. The majority of spent fuel discharges (51 percent) were between 25,000) and 30,(100) MWDT/MTIHM. For pressurized-water reactors, the average equilibrium spent fuel discharge burnup in 1989 was about 35,00() MWDT/MTIHM. The values ranged from under 20,000 to over 50,000$)$ MWDT/MTIHM, with the majority of spent fuel discharges (46 percent) between 35,000) and 40,0)(0) MWDT/MTIHM. Appendix D shows projected equilibrium discharge burnup levels from 1990) through 2()2().

Design burnup levels for U.S. commercial nuclear fuel in the early 1980's were around $28,(000$ and $33,00(0)$ MWDT/MTIIIM for boiling-water reactors and pressurized-water reactors, respectively. Engineering advances in fuel integrity and improved fuel management techniques were developed through a joint effort by Covernment and industry, resulting in higher design burnups. In this report, fuel with design burnup above $28,0(0)$ MWD'T/M'TH $1 \mathrm{M}$ for boiling-water reactors and 33,0)(0) MWIOT/MTIIIM for pressurized-water reactors is refered to as "extended burmup fuel." The following pages of this Appendix describe the procedures used to develop fuel plans associated with extended fuel burnup levels.

A fuel plan consists of:

- Amount of uranium loaded

- Enrichment assay of the uranium loaded

- Plarned number of full-power days

- Design burnup ievel of the discharged spent fuel.

In an ideal equilibrium cycle, any two of the above parameters determine the other two parameters. The equations relating the parameters are:

$$
F B=S D,
$$

and

$$
E=a+b B(1+F),
$$

where:

$F=$ fraction of the core being replaced in an equilibrium reloading,

$B=$ equilibrium discharge batch average burnup (megawattdays thermal per metric ton of initial heavy metal),

$D$ = equilibrium full-power days (days),

$S=$ core specific power (megawatts thermal per metric ton of initial heavy metal),

$E=$ enrichment assaly (percent),

and $a$ and $b$ are regression coefficients.

The fraction of the core replaced is functionally equivalent to the amount of enriched uranium loaded.

Equation (1) implies that in an equilibrium mode, the core average burnup, SD, equals the discharge batch average burnup, $B$, times the batch fractional average, $F$. For example, if $F=1 / 3$ and $B=33,000$ megawattdays thermal per metric ton of initial heavy metal, then the core average burnup is 11,000$)$ megawattdays thermal per metric ton of initial heavy metal. That is, a batch of fuel stays in the core for three cycles, receiving an exposure of $11,(0)()$ megawattdays thermal per metric ton of initial heavy motal during each cycle. The core specific power, $S$, depends on the particular reactor and core configuration being considered. However, there is a high corrolation between core specific power and the ratio of the 
reactor's rated thermal power to core size (uranium content), so that for modeling purposes, $S$ can be considered invariant for an individual reactor.

Equation (2) assumes a linear reactivity model, that is, that the rate of change of reactivity with fuel burnup is constant. The parameters $a$ and $b$ are fixed values determined from the analysis of a coupled thermalhydraulic nuclear fuel cycle; $b$ depends on bundle design, and $a$ depends on leakage. Both $a$ and $b$ can be affected by design variables governing the conversion ratio and change in the slope of reactivity versus burnup. In an ideal equilibrium cycle, Equation (2) may be interpreted as relating enrichment assay to total burnup, where total burnup is defined as the sum of the discharge burnup, $B$, and the cycle equilibrium burnup, $B F$. In practice, the assumption of a linear relationship between enrichment assay and total burnup must be tempered because of the incorporation of burnable poisons with the nuclear fuel. Burnable poisons are used in higher burnup fuel to control reactivity and limit power peaking. The addition of burnable poisons to the nuclear fuel requires moderate increases in enrichment assays to obtain a given burnup objective. This additional U-235 requirement introduces an upward concavity in the enrichment-burnup relationship. However, Equation (2) does provide a good estimate of the relationship over a reasonable burnup range.

Under the conditions described above, Equations (1) and (2) provide a reasonable approximation for an ideal equilibrium cycle. To obtain generic parameters characterizing a typical boiling-water reactor and pressurized-water reactor, estimates of the coefficients in Equation (2) are obtained over two separate burnup ranges.

The first range is from 28,148 to 36,593 megawattdays thermal per metric ton of initial heavy metal for boiling-water reactors and 32,281 to 41,966 megawattdays thermal per metric ton of initial heavy metal for domestic pressurized-water reactors. The second burnup range is from 36,593 to 42,222 megawattdays thermal per metric ton of initial heavy metal for boiling-water reactors and 41,966 to 48,422 megawattdays thermal per metric ton of initial heavy metal for pressurized-water reactors.

Instead of Equation (2), a similar equation was estimated:

$$
E=a_{1}+b_{2} B+b_{2} F .
$$

Equation (3) was used because it resulted in a better fit.

The regression parameters in Equations (4) and (5) below were estimated by a multiple regression analysis applied to fuel management projections.
These projections were supplied to DOE by utilities on Form RW-859 and incorporated into ElA's Integrated Nuclear Information System (INIS). Separate estimates were made for boiling-water reactors and pressurized-water reactors. Only fuel with zircalloy cladding was considered. P'rior to applying the regression analysis, anomalous data were identified and eliminated from the analysis set. The R-squared values were 0.81 for pressurized-water reactors and 0.80 for boiling-water reactors (Table B1).

The " $f$ " test was used to test the regression coefficients against the null hypothesis that they were not significantly different from zero. This test produces a statistical measure for determining whether a variable should be included in the model. In all cases, the coefficients were statistically significant at the 0.0001 level (Table B2).

Substituting the results of the regression analysis in Equation (3) yields the following expressions. For boiling-water reactors.

$$
E=0.327+0.000(0661 B+2.12 F .
$$

For pressurized-water reactors:

$$
E=0.6(0) 3+0.00000571 B+2.13 F .
$$

The projected discharge burnup data from Form RW-859, "Nuclear Fue! Data Survey," that was used in this analysis peaked at 38,000) megawattdays thermal per metric ton of initial heavy metal for boiling-water reactors and 46,(0)(0) megawattdays thermal per metric ton of initial heavy metal for pressurized-water reactors. Equations (4) and (5) are not applied to burnup levels exceeding these limits, because utilities are only now developing fuel management plans for burnup levels past these limits, and utility-supplied data for fuel management plans associated with these higher burnup goals are not currently available. For higher burnup ranges, the following analysis is used to establish the relationship between burnup, enrichment assay, and core replacement fraction.

Estimates of the technical parameters in Equation (2) were supplied by General Electric Corporation. Equation (2) can be written in the following difference format:

$$
E=|\Delta \Delta| B(1+F) \mid,
$$

where $\Delta$ indicates the difference operator. This equation is applied to a given fuel management plan consisting of an assay $E_{2}$, a burnup $B$, and a core fraction $F_{1}$. If a new fuel management plan has a burnup $B_{2}$ and a core fraction $F_{2}$, then

$$
\Delta|B(1+r)|=B_{2}\left(1+F_{2}\right)-B_{1}\left(1+F_{1}\right)
$$


Table B1. Results of the Regression Analysis of the Enrichment Assay Equations

\begin{tabular}{|c|c|c|c|c|c|}
\hline Reactor Type & $\begin{array}{l}\text { Independent } \\
\text { Varlable }\end{array}$ & Intercept & $\begin{array}{l}\text { Burnup } \\
\text { Coefflcient }\end{array}$ & $\begin{array}{c}\text { Core-Fraction } \\
\text { Coefflcient }\end{array}$ & R-squared \\
\hline $\begin{array}{l}\text { Boilling-Water Reactor . . . } \\
\text { Pressurized-Water Reactor }\end{array}$ & $\begin{array}{l}\text { Assay } \\
\text { Assay }\end{array}$ & $\begin{array}{l}0.327 \\
0.603\end{array}$ & $\begin{array}{l}0.0000661 \\
0.0000571\end{array}$ & $\begin{array}{l}2.12 \\
2.13\end{array}$ & $\begin{array}{l}0.80 \\
0.81\end{array}$ \\
\hline
\end{tabular}

Table B2. Results of the Regression Coefficient Tests

Reactor Type

Parameter
Boillng-Water Reactor

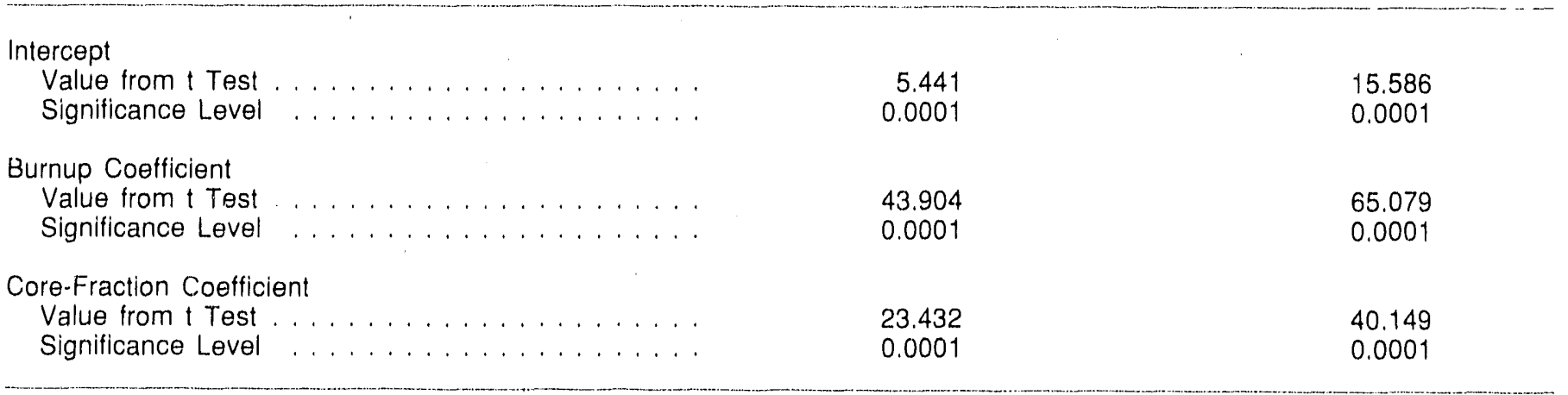

The change in enrichment assay is calculated by $\Delta E=b \Delta \mid B(1+F)\}$, and the new enrichment assay is given by $E_{2}=E_{1}+E$.

General Electric Corporation suggested that an appropriate value of $b$ in the higher burnup ranges is 0.00063 . This value of $b$ provides a good approximation for both boiling-water reactors and pressurized-water reactors. Note that the :alue of the parameter $a$ in Equation (2) depends on the generic reactor type. Using the Cieneral Electric Corporation value for b, Equation (6) becomes

$$
\Delta E=0.000063 \Delta[B(1+F)] \text {. }
$$

As Equation (1) indicates, for a given discharge burnup and a given number of effective full-power days per cycle, the core fraction depends on the specific power of the reactor. However, the reactor fuel management plans used in INM depend on the generic reactor type and not on the specific power of an individual reactor. The current fuel management plans were statistically derived from actual operating data and apply to the entire boiling-water reactor and pressurized-water reactor systems of a given region. As such, they implicitly incorporate a mean specific power value for a generic boiling-water reactor and pressurized-water reactor.

Using the current fuel diet plan as a starting point, Equation (1) is used to calculate the core fraction of a new fuel diet plan,

$$
F_{2}=\left(F_{1} D_{2} B_{1}\right) /\left(D_{1} B_{2}\right)
$$

where:

$F_{2}=$ core fraction of new fuel management plan,

$F_{1}=$ core fraction of historical fuel management pian,

$D_{2}=$ effective full-power days of new fuel management plan,

$D_{1}=$ effective full-power days of historical fuel management plan,

$B_{2}=$ discharge burmup of new fuel management plan, and

$B_{1}=$ discharge burnup of historical fucl management plan. 
Equation (9) removes the explicit reference to specific energy, which is implicitly incorporated in the historical fuel management plans.

Utilities ustaally develop their fuel management plans to meet effective full-power days and discharge burnup goals. That is, they specify the amount of energy to be produced during the cycle and the desired discharge burnup of the fuel, and use these objectives to determine the amount and enrichment assay of the fresh uranium loaded. The burnup objectives are generally determined by economic and operational considerations.

Domestic and foreign fuel management plans for extended burnup are developed for generic boilingwater reactors and pressurized-water reactors (Tables B3 and B4). Associated with each level of increased burntp is the number of effective full-power days per cycle. Effective full-power day plans were obtained from utility-surplied data and industry experts. The number of effective full-power days is based on the equilibrium cycle capacity factor assumptions and an 18-month cycle length.

The following five steps were used to develop fuel models consistent with increases in fuel burnup and the number of effective full-power days per cycle. The procedure was applied separately to generic boiling-water reactors and pressurized-water reactors and for domestic and foreign reactors.
1. Historical fuel models were estimated statistically from reactor ope ation data.

2. Equations (4) and (5) were used to estimate the design burnup associated with the historical fuel models. The base year historical fuel model was 1984 for domestic reactors and 1987 for foreign reactors.

3. The core fraction associated with a given burnup level and number of effective fullpower days was computed by Equation (9).

4. The specified burnup level and the core fraction calculated in step 2 were used to estimate the enrichment assay. In the domestic fuel management plans for years 199()-1994 for BWR's and 1990-2004 for PWR's, Equations (4) and (5) were used to estimate the enrichment assay. For the remaining years, Equation (8) was used to estimate the change in the enrichment assay, based on the increased burnup and change in core fraction.

5. The amount of uranium to be loaded was calculated as the product of the core fraction computed in step 3 and the total core weight.

Table B3. Domestic Fuel Management Plans for Extended Burnup Scenarios

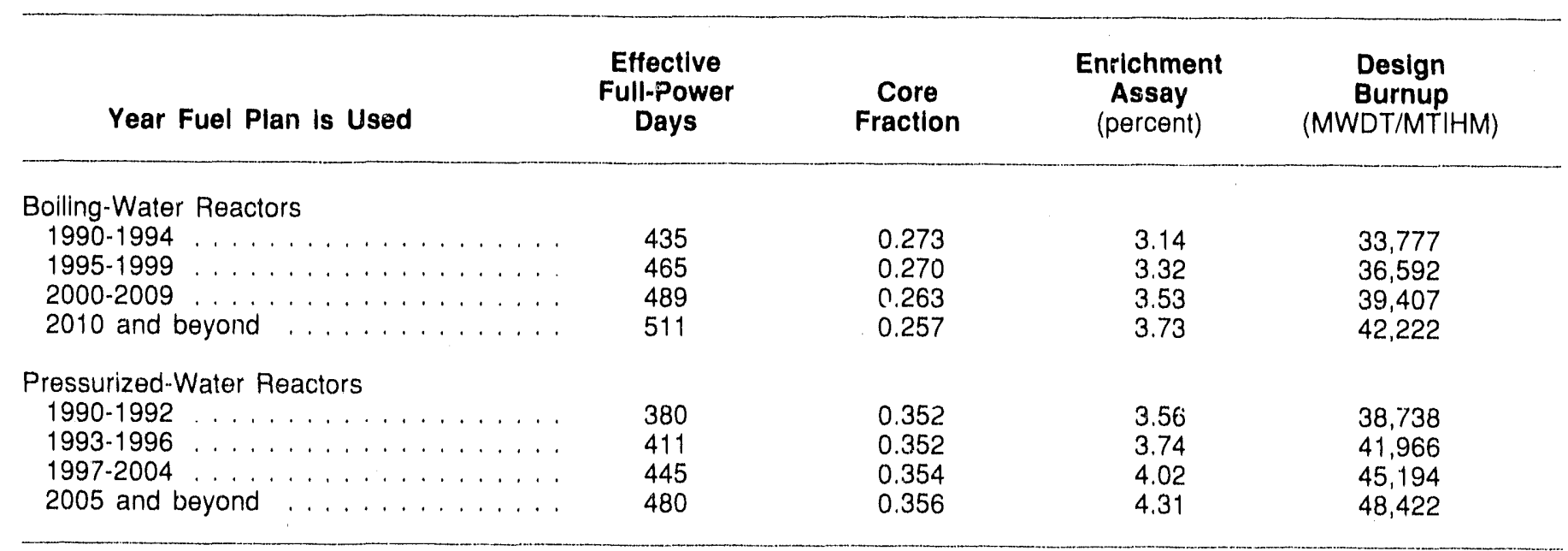


Table B4. Forelgn Fuel Management Plans for Extended Burnup Scenarios

\begin{tabular}{|c|c|c|c|c|}
\hline Year Fuel Plan is Used & $\begin{array}{l}\text { Effective } \\
\text { Full-Power } \\
\text { Days }\end{array}$ & $\begin{array}{c}\text { Core } \\
\text { Fraction }\end{array}$ & $\begin{array}{c}\text { Enrichment } \\
\text { Assay } \\
\text { (percent) }\end{array}$ & $\begin{array}{c}\text { Design } \\
\text { Burnup } \\
\text { (MWDT/MTIHM) }\end{array}$ \\
\hline \multicolumn{5}{|l|}{ Europe } \\
\hline 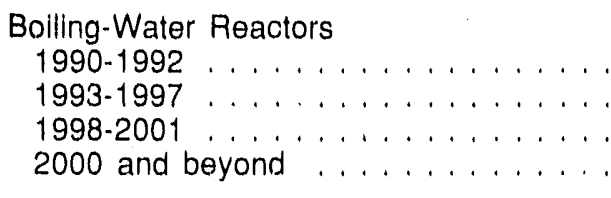 & $\begin{array}{l}305 \\
305 \\
305 \\
305\end{array}$ & $\begin{array}{l}0.214 \\
0.195 \\
0.178 \\
0.165\end{array}$ & $\begin{array}{l}3.00 \\
3.18 \\
3.37 \\
3.56\end{array}$ & $\begin{array}{l}33,575 \\
36,932 \\
40,290 \\
43,647\end{array}$ \\
\hline 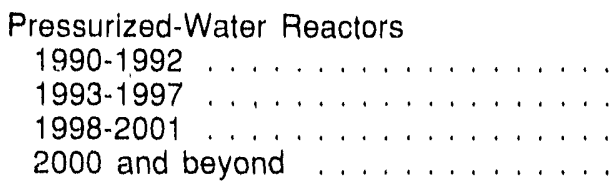 & $\begin{array}{l}283 \\
292 \\
292 \\
292\end{array}$ & $\begin{array}{l}0.293 \\
0.275 \\
0.252 . \\
0.232\end{array}$ & $\begin{array}{l}3.38 \\
3.56 \\
3.72 \\
3.90\end{array}$ & $\begin{array}{l}37,773 \\
41,550 \\
45,327 \\
49,104\end{array}$ \\
\hline Far East & & & & \\
\hline 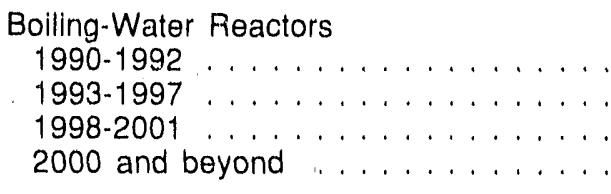 & $\begin{array}{l}366 \\
366 \\
370 \\
380\end{array}$ & $\begin{array}{l}0.286 \\
0.260 \\
0.241 \\
0.228\end{array}$ & $\begin{array}{l}3.02 \\
3.17 \\
3.34 \\
3.52\end{array}$ & $\begin{array}{l}31,568 \\
34,725 \\
37,882 \\
41,039\end{array}$ \\
\hline 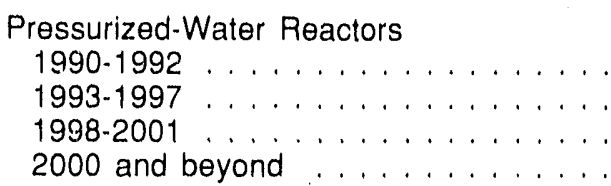 & $\begin{array}{l}345 \\
350 \\
355 \\
375\end{array}$ & $\begin{array}{l}0.403 \\
0.372 \\
0.346 \\
0.337\end{array}$ & $\begin{array}{l}3.38 \\
3.51 \\
3.64 \\
3.82\end{array}$ & $\begin{array}{l}33,689 \\
37,057 \\
40,426 \\
43,795\end{array}$ \\
\hline
\end{tabular}


Appendix C

Nuclear Fuel Cycle

Facilities That Prepare Fuel for Nuclear Power Plants 


\section{Nuclear Fuel Cycle Facllities That Prepare Fuel for Nuclear Power Plants}

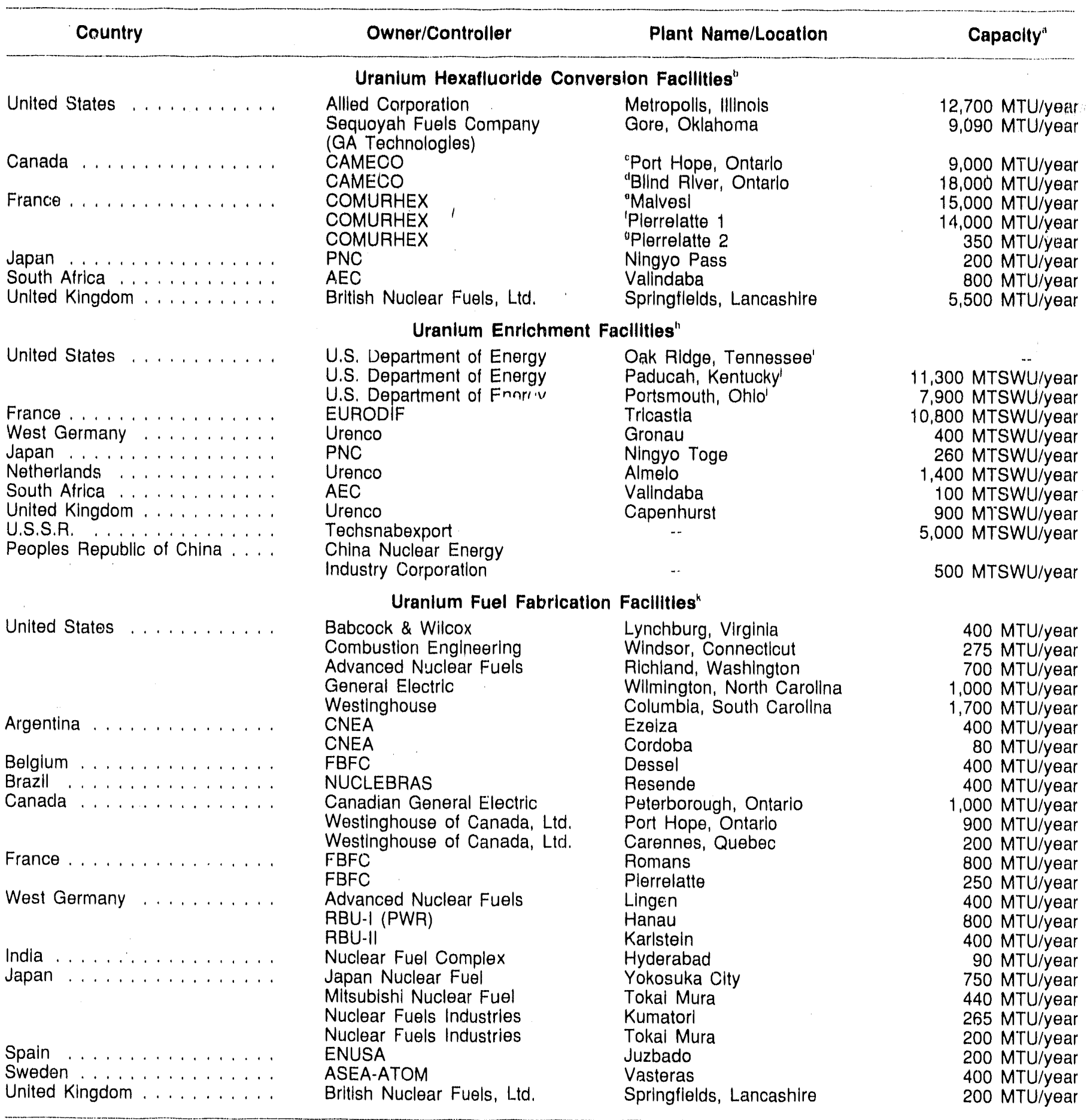

"Status as of February 1990. MTU, metric tons of uranlum; MTSWU, metric tons of separative work units.

"Nuclear Assurance Corporation, Fuel-Trac Reports, "UF, Status Report" (Atlanta, GA, February 1990).

$\mathrm{CUO}_{3}$ to $\mathrm{UF}_{0}$.

${ }^{\mathrm{d}} \mathrm{U}_{3} \mathrm{O}_{8}$ to $\mathrm{UO}^{0^{*}}$

${ }^{2} \mathrm{U}_{3} \mathrm{O}_{8}$ to $\mathrm{UF}_{4}$.

'UF ${ }_{4}$ to $U F_{0}$.

"Conversion of reprocessed (irradlated) $\mathrm{UO}_{3}\left(\mathrm{NO}_{3}\right)_{2}$ to $\mathrm{UF}_{0}$

"Nuclear Assurance Corporation, Fuel-Trac Reports, "Enrichment Status Report" (Atlanta, GA, February 1990).

'This facility, which had been on standby since 1986, was closed on December 15, 1987.

U.S. Department of Energy, Offlce of the Assistant Secretary for Nuclear Energy.

"Nuclear Assurance Corporation, Fuel-Trac Reports, "LWR Fabrication Status Report" (Atlanta, GA, February 1990). 
Appendix D

Projections of

U.S. Spent Fuel Discharges, 1990-2040 


\section{Appendix D \\ Projections of U.S. Spent Fuel Discharges, 1990-2040}

The projections contained in this appendix were developed in accordance with the assumptions detailed in Appendix B. Table D1 provides annual projections of spent fuel discharges in the United States for each of the nuclear supply scenarios and three burnup sensitivity cases. The cumulative totals are contained in Table D2. The projected average discharge burnup of the spent fuel for equilibrium cycler only is shown in Table D3. Table D4 contains average burnup of spent fuel discharged for all cycles. The projections for the No New Orders case are extended beyond 2020 to estimate the total spent fuel when all nuclear generating units are retired. The year 2040 is the last year in which fuel is projected to be discharged in the No New Orders case.

Projections of spent fuel discharges for all the nuclear supply scenarios were developed using the base case burnup assumptions shown in Appendix B, Table B3.

The alternative scenarios for spent fuel discharges assume (1) Lower-Reference-case capacity levels with less increase in burnup beyond current levels, (2) Lower-Reference-case capacity levels with continued increases in burnup to 47,000 for BWR's and 52,000 for PWR's by 2020, (3) No New Orders with less increase in burnup above current levels, and (4) No New Orders with continued increase in Durnup similar to that described in (3).

In additir $n$ to displaying aggregate spent fuel projections shown in Tables D1 and D2, disaggregated projections are presented for each fuel cycle of each nuclear reactor in Tables D5 through D9.

Under the Nuclear Waste Policy Act of 1982, as amended, the U.S. Department of Energy is responsible for developing the waste disposal system for spent nuclear fuel and high-level radioactive waste. To plan for an effective waste management program, the Office of Civilian Radioactive Waste Management (OCRWM) needs to know the range and distribution cif characteristics of the spent fuel expected to be received by the Government. Hence, OCRWM requirss disaggregate spent fuel projections (that is, for individual reactors) for use in waste stream analyses and logistics planning. Since the International Nuclear Model (INM) forecasts are predicated on generic reactor types, there are no differences in the spent fuel forecasts for individual reactors of the same generic type, other than linear scaling of spent fuel discharges to reactor size and differences in capacity factors.

The Energy Information Administration (EIA) administers Forrn RW-859, "Nuclear Fuel Data," which is used to collect data from U.S. utilities on projected spent fuel discharges. These data are processed by EIA and incorporated into the Integrated Nuclear Information System (INIS). The data from INIS form the basis for disaggregate spent fuel forecasts.

The EIA uses the INM to project aggregate spent fuel discharges and electricity generation for domestic nuclear reactors. These forecasts are based on the operating characteristics of generic boiling-water reactors and pressurized-water reactors. To produce the forecasts, EIA develops a set of operational assumptions for capacity factors, fuel burnup levels, and installed nuclear capacity, as described in the body of this report, and uses a set of generic fuel management plans for boiling-water reactors and pressurized-water reactors, as described in Appendix B. Estimates of nuclear fuel cycle trends are determined by surveying utilities, fuel vendors, and other industry experts. The fuel management plans for the INM are derived statistically from historical operating data and from utilities' projected fuel management schemes.

The utility projections supplied on Form RW-859 are for only the upcoming five fuel cy'cles and do not cover the entire forecast period covered by EIA projections. Moreover, there are some differences between the aggregate assumptions inherent in the utility projections and those used by EIA, so that there are differences between the totals in the two sets of projections. This divergence occurs for two reasons. First, utilities are optimistic in their planning and do not take into account unanticipated outages. Second, utilities project only five fuel cycles into the future. This period covers only the first part of the time frame over which EIA assumes an increasing trend in the burnup level of discharged spent fuel. Indeed, many utilities have indicated that they are investigating plans for discharge burnup levels that 
would be higher than those reported on Form RW-859.

To reconcile the differences between the INM and INIS forecasts, EIA has developed a disaggregate spent fuel forecasting program, DISAG, which calibrates the reactor-specific projections made by the utilities to the aggreg ?te INM projections. The calibration methodology preserves the INM aggregate projections of annual spent fuel discharges and electricity generation by adjusting the utilities' reactorspecific projections of capacity factors and fuel burnup levels. The methodology also preserves the nature and shape of the burnup distributions projected by the utilities.

\section{Overview}

To understand the methodology used in disaggregating the aggregate forecasts, it is instructive to look at the factors used to make the aggregate INM forecasts, and to highlight the differences between the aggregate and reactor-specific assumptions. In the aggregate INM forecasts, domestic reactors are divided into two major categories-boiling-water reactors and pressurizedwater reactors-and average operating characteristics are assumed for the individual reactors in each category. This formalism facilitates the statistical representation of unplanned outages by using a systemwide capacity factor for each reactor type, based on actual operating experience. While statistical techniques are appropriate for systemwide analysis, it is not possible to predict unplanned outages for individual reactors. Reactor operations projected by utilities do not, as a rule, account for unanticipated problems. Consequently, they assume a significantly more efficient systemwide operating environment than has beeil achieved in the recent past.

In the INM, reactor fuel management plans are defined at the cycle level, whereas utilities project at the batch level. (A batch is a group of assemblies with similar characteristics, such as initial loading weight and enrichment, and discharge burnup.) Consequently, each reactor discharge is characterized in the utility projections by a range of burnup levels. The utilities also project reactor full-power days and cycle shutdown times, which implicitly determine capacity factors (full-power days divided by cycle length).

The development of the disaggregating methodology was guided by the following objectives:

- The methodology must preserve the aggregate energy and spent fuel projections of the INM forecasts.
- It must maintain, to the extent possible, the fuel management projections made by the utiities, especially with regard to burnup distributions.

- Any adjustments to individual utility forecasts must be explainable in terms of differences between the aggregate burnup and capacity factor assumptions used in the INM forecasts and those used by the utilities.

The INM forecasts are predicated on assumptions about trends in discharge burnup levels and reactor capacity factors. For a given level of installed nuclear capacity, the capacity factor assumptions determine the amount of energy produced, while burnup assumptions determine the quantity of spent fuel that will be generated in producing that energy. Energy production, fuel burnup, and spent fuel generation are functionally related by the following equation:

$$
\text { ENERGY }=\text { BURNUI } \times \text { SPENT FUEL . }
$$

Given any two variables in the above equation, the third variable is uniquely determined. Thus, the objective of preserving the energy and spent fuel projections of the INM forecasts is equivalent to preserving the burnup and capacity factor assumptions used for the INM forecasts.

\section{Capacity Factors}

In the INM, capacity factors are the primary determinant of energy production, which is modeled by the following equation:

$$
\begin{aligned}
\text { ENERGY }= & \text { INSTALLED CAPACITY } \\
& \times \text { CAPACITY FACTOR } \times \text { TIME . }
\end{aligned}
$$

EIA scenarios are based on assumptions about trends in capacity factors, which are derived from current capacity factors. To determine the current capacity factors for operating reactors, EIA has statistically analyzed historical reactor operating experience and derived capacity factors representative of the domestic nuclear power industry as a whole. (Boiling-water reactors and pressurized-water reactors are treated separately.) These aggregate capacity factors adequately represent the domestic industry as a whole, since there are a sufficient number of operating reactors to statistically capture unplanned outages on a systemwide basis. Individual reactors, however, exhibit a broad range of operating efficiencies, and an aggregate capacity factor does not represent any single reactor.

Consequently, EIA has stratified reactors with sufficient operating history into capacity factor groups. Eight groups have been defined-four for boiling- 
water reactors and four for pressurized-water reactors. The groups are defined on the basis of their average capacity factor characteristics: low, medium, high, and very high. The assignment of capacity factors to each group is based on the historical performance of the reactors in the group. It is important to note that the aggregate capacity factor for each group, derived from the historical capacity factors for the individual reactors assigned to the group, is consistent with the systemwide aggregate capacity factor.

For modeling purposes, a reactor's energy production is determined by its capacity factor. As a result, the assumptions used by EIA for the different capacity factor groups also stratify reactor energy production. These assumptions carry over directly to the disaggregation process.

As noted above, the capacity factors implicit in utility projections are generally optimistic and do not include allowances for unplanned outages. In the aggregate, the utilities' projected capacity factors exceed recent historical capacity factors by 15 to 20 percent. For individual reactors, the relationship between historical and projected capacity factors is very erratic. For 2 reactors the projected capacity factors are less than historical values, and for 85 reactors the projected capacity factors are 2 to 140 percent higher than historical values.

\section{Burnup}

On Form RW-859, utilities project discharge burnup levels for the next five cycles of reactor operation. With the objective of preserving aggregate energy and spent fuel projection from the INM, the fuel management projections made by the utilities on Form RW-859, especially with regard to burnup distribution are used to project reactors specific spent fuel discharges. The EIA burnup sensitivity cases study alternative trends in increased burnup, which also vary from the burnup trends in the utility-propagated data.

The EIA base case assumes a continuing increase in burnup levels beyond those inherent in the utility data, with the design equilibrium burnups reaching 40,600 megawattdays thermal per metric ton of initial heavy metal for boiling-water reactors in 2000 and 45,000 megawattdays thermal per metric ton of initial heavy metal for pressurized-water reactors around 1997.

\section{Adjustment Procedure}

In the disaggregation procedure, each reactor is assumed to operate with the capacity factor assigned to it in the INM forecast. That is, each reactor's energy production is determined by its capacity factor in the INM. The disaggregate adjustments for spent fuel discharges and burnup levels are made for individual reactors in the energy or full-power-day domain. When the full-power-day domain is used, no adjustments are required for energy production, and the objective of preserving the energy production levels from the INM is automatically satisfied.

To reconcile the differences between annual burnup levels in the utility data and in the INM forecast, a set of annual adjustment factors is developed to bring the utility projections in line with the INM forecasts by comparing annual spent fuel forecasts from the two data series. Discharge burmups are adjusted inversely to the adjustments in spent fuel discharges, keeping energy generation constant.

As noted above, all adjustments are made in the fullpower-day or energy domain, to yield a simple interpretation of the adjustments made for individual reactors. Annual adjustment factors are essentially the ratio of mean annual discharge burnups from the utility data to those from the INM forecasts. For instance, if the utility data indicate a mean discharge burnup level for pressurized-water reactors of 39,000 megawattdays thermal per metric ton of initial heavy metal and the INM forecast shows a mean discharge burnup level of 43,000 megawattdays thermal per metric ton of initial heavy metal for a given year, the amount of fuel discharged from the reactor is adjusted downward by about 10 percent, and the discharge burnup of each batch is adjusted upward by about 10 percent for that year. Initial fuel enrichment levels are also adjusted when burnups are adjusted. The adjustments to enrichment levels are based on the formulas given in Appendix C.

\section{Near-Term Use of Utility Data}

Much of the fuel scheduled to be discharged over the next three or four cycles has already been loaded into the reactors or, at least, firmly ordered. It is felt that the utilities can make the best projections of the amounts and burnup levels of spent fuel discharges for this period. Therefore, the utility data are used directly for near-term disaggregate forecasts. However, since the capacity factors implied by the utility data are significantly overestimated in comparison with the EIA assumptions, they are not used. Rather, cycle lengths are derived by dividing the number of full-power days by the capacity factor assigned by EIA. The date of the first projected discharge for each reactor in the INM database is set to the date provided by the utility. 


\section{Generic Reactors}

Some EIA projections inclucie data for generic or as yet unidentified reactors that are projected to come on line after the year 2000. Since these are hypothetical reactors, there are no utility projections for their fuel management plans. Therefore, the discharges assigned to these reactors are derived from the generic fuel management plans used in the INM. That is, only existing reactors are subject to the disaggregation procedure. 
Table D1. Projections of Annual U.S. Spent Fuel Discharges ${ }^{a}$

(Thousand Metric Tons of Initial Heavy Metal)

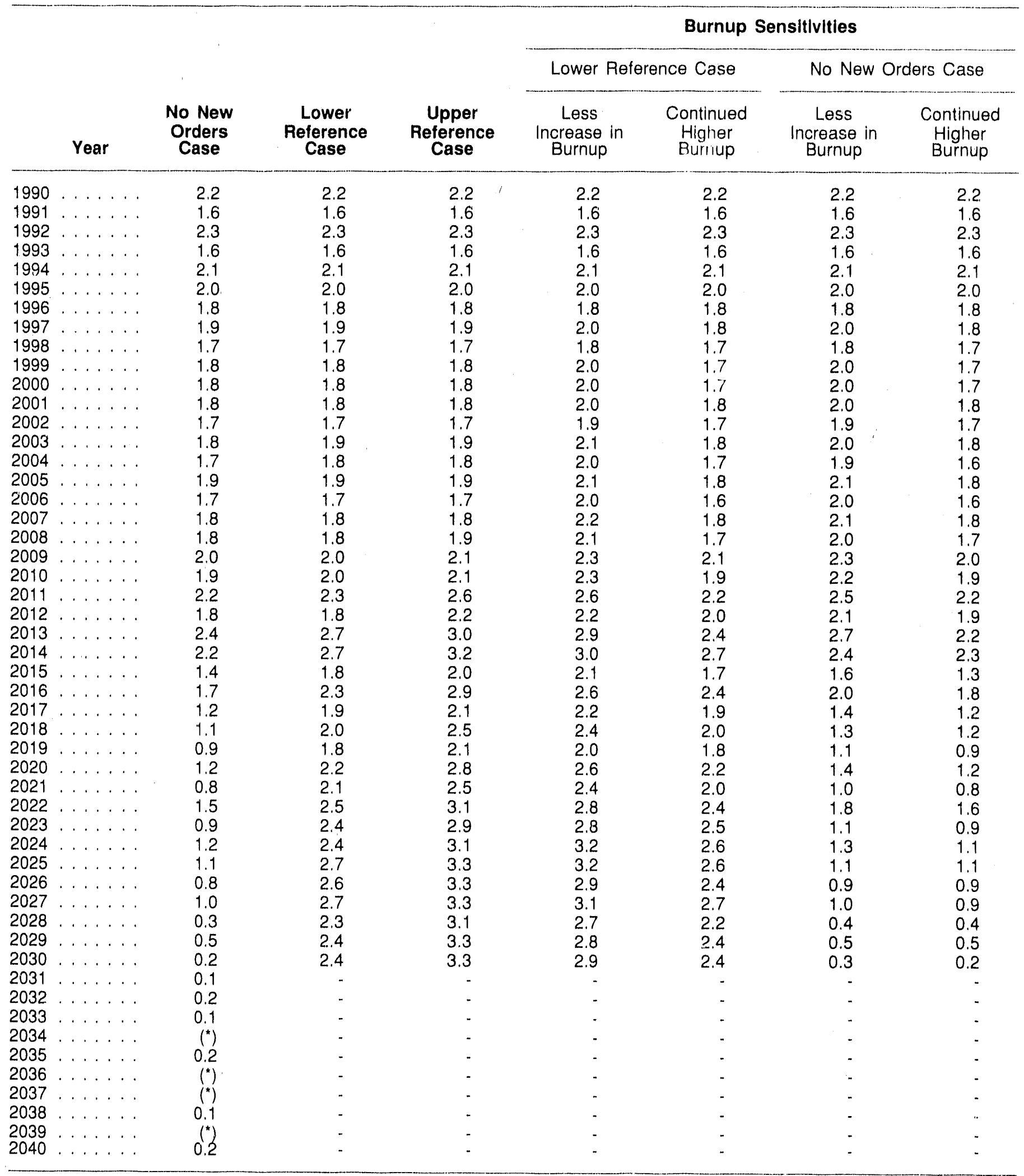

aSpent fuel discharges beyond the year 2030 are projected only in the No New Orders Case.

"Less than 50 metric tons.

Source: Projections derived from the Iriternational Nuclear Model and Form RW-859, "Nuclear Fuel Data" (1989). 
Table D2. Projections of Total U.S. Spent Fuel Discharges"

(Thousand Metric Tons of Initial Heavy Metal)

\begin{tabular}{|c|c|c|c|c|c|c|c|c|}
\hline & \multirow[b]{3}{*}{ Year } & \multirow[b]{3}{*}{$\begin{array}{l}\text { No New } \\
\text { Orders } \\
\text { Case }\end{array}$} & \multirow[b]{3}{*}{$\begin{array}{l}\text { Lower } \\
\text { Reference } \\
\text { Case }\end{array}$} & \multirow[b]{3}{*}{$\begin{array}{c}\text { Upper } \\
\text { Reference } \\
\text { Case }\end{array}$} & \multicolumn{4}{|c|}{ Burnup Sensitivities } \\
\hline & & & & & \multicolumn{2}{|c|}{ Lower Reference Case } & \multicolumn{2}{|c|}{ No New Orders Case } \\
\hline & & & & & $\begin{array}{c}\text { Less } \\
\text { Increase in } \\
\text { Burnup }\end{array}$ & $\begin{array}{l}\text { Continued } \\
\text { Higher } \\
\text { Burnup }\end{array}$ & $\begin{array}{c}\text { Less } \\
\text { Increase in } \\
\text { Burnup }\end{array}$ & $\begin{array}{c}\text { Continued } \\
\text { Higher } \\
\text { Burnup }\end{array}$ \\
\hline 1990 & $\ldots$ & 21.8 & 21.8 & 21.8 & 21.8 & 21.8 & 21.8 & 21.8 \\
\hline 1991 & $\ldots$ & 23.4 & 23.4 & 23.4 & 23.4 & 23.4 & 23.4 & 23.4 \\
\hline 1992 & $\ldots$. & 25.8 & 25.8 & 25.8 & 25.8 & 25.8 & 25.8 & 25.8 \\
\hline 1993 & $\ldots$ & 27.4 & 27.4 & 27.4 & 27.4 & 27.4 & 27.4 & 27.4 \\
\hline 1994 & $\ldots \ldots$ & 29.5 & 29.5 & 29.5 & 29.5 & 29.5 & 29.5 & 29.5 \\
\hline 1995 & $\ldots \ldots$ & 31.4 & 31.4 & 31.4 & 31.4 & 31.4 & 31.4 & 31.4 \\
\hline 1996 & $\ldots \ldots$ & 33.2 & 33.2 & 33.2 & 33.3 & 33.3 & 33.3 & 33.3 \\
\hline 1997 & $\ldots \ldots$ & 35.1 & 35.1 & 35.1 & 35.2 & 35.1 & 35.2 & 35.1 \\
\hline 1998 & $\ldots$ & 36.9 & 36.9 & 36.9 & 37.1 & 36.8 & 37.1 & 36.8 \\
\hline 1999 & $\ldots$ & 38.7 & 38.7 & 38.7 & 39.1 & 38.5 & 39.1 & 38.5 \\
\hline 2000 & $\ldots$ & 40.4 & 40.4 & 40.4 & 41.0 & 40.3 & 41.0 & 40.3 \\
\hline 2001 & $\ldots$ & 42.2 & 42.2 & 42.2 & 43.0 & 42.1 & 43.0 & 42.1 \\
\hline 2002 & $\ldots$ & 44.0 & 44.0 & 4.4 .0 & 45.0 & 43.8 & 45.0 & 43.7 \\
\hline 2003 & $\ldots$ & 45.8 & 45.8 & 45.8 & 47.1 & 45.6 & 47.0 & 45.5 \\
\hline 2004 & $\ldots$ & 47.5 & 47.6 & 47.6 & 49.0 & 47.2 & 49.0 & 47.2 \\
\hline 2005 & . . . . & 49.4 & 49.4 & 49.4 & 51.2 & 49.0 & 51.1 & 49.0 \\
\hline 2006 & $\ldots$ & 51.1 & 51.2 & 51.2 & 53.2 & 50.7 & 53.1 & 50.6 \\
\hline 2007 & . . . . & 52.9 & 53.0 & 53.0 & 55.3 & 52.5 & 55.2 & 52.3 \\
\hline 2008 & $\ldots$ & 54.7 & 54.8 & 54.9 & 57.4 & 54.2 & 57.2 & 54.1 \\
\hline 2009 & $\ldots$ & 56.6 & 56.8 & 57.0 & 59.7 & 56.3 & 59.5 & 56.1 \\
\hline 2010 & $\ldots$ & 58.6 & 58.8 & 59.1 & 62.0 & 58.2 & 61.7 & 57.9 \\
\hline 2011 & $\ldots \ldots$ & 60.8 & 61.1 & 61.7 & 64.6 & 60.4 & 64.2 & 60.1 \\
\hline 2012 & $\ldots$ & 62.6 & 62.9 & 63.8 & 66.8 & 62.4 & 66.3 & 62.0 \\
\hline 2013 & $\ldots \ldots$ & 65.0 & 65.6 & 66.9 & 69.7 & 64.9 & 69.1 & 64.3 \\
\hline 2014 & $\ldots$ & 67.2 & 68.3 & 70.1 & 72.7 & 67.6 & 71.4 & 66.6 \\
\hline 2015 & $\ldots$ & 68.5 & 70.0 & 72.0 & 74.8 & 69.3 & 73.1 & 67.9 \\
\hline 2016 & $\ldots$ & 70.3 & 72.4 & 74.9 & 77.5 & 71.7 & 75.0 & 69.6 \\
\hline 2017 & . & 71.5 & 74.2 & 77.0 & 79.6 & 73.6 & 76.5 & 70.8 \\
\hline 2018 & . & 72.6 & 76.2 & 79.6 & 82.1 & 75.6 & 77.8 & 72.0 \\
\hline 2019 & $\ldots$ & 73.6 & 78.1 & 81.7 & 84.1 & 77.4 & 78.9 & 72.9 \\
\hline 2020 & $\ldots$ & 74.8 & 80.2 & 84.4 & 86.6 & 79.6 & 80.3 & 74.1 \\
\hline 2021 & & 75.6 & 82.3 & 86.9 & 89.1 & 81.6 & 81.3 & 74.9 \\
\hline 2022 & $\ldots$ & 77.1 & 84.8 & 90.0 & 91.9 & 84.0 & 83.1 & 76.5 \\
\hline 2023 & $\ldots$ & 78.0 & 87.3 & 92.9 & 94.7 & 86.5 & 84.1 & 77.4 \\
\hline 2024 & $\ldots$ & 79.2 & 89.7 & 96.0 & 97.8 & 89.1 & 85.4 & 78.5 \\
\hline 2025 & $\ldots$ & 80.3 & 92.4 & 99.3 & 101.0 & 91.7 & 86.5 & 79.6 \\
\hline 2026 & & 81.1 & 95.0 & 102.6 & 103.9 & 94.1 & 87.4 & 80.5 \\
\hline 2027 & & 82.1 & 97.7 & 105.9 & 107.0 & 96.8 & 88.4 & 81.4 \\
\hline 2028 & & 82.4 & 100.0 & 109.0 & 109.7 & 99.0 & 88.8 & 81.8 \\
\hline 2029 & & 82.9 & 102.4 & 112.3 & 112.5 & 101.4 & 89.3 & 82.3 \\
\hline 2030 & & 83.2 & 104.8 & 115.6 & 115.4 & 103.8 & 89.6 & 82.5 \\
\hline 2031 & & 83.3 & 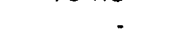 & . & 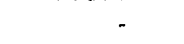 & 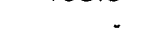 & - & . \\
\hline 2032 & & 83.5 & - & - & - & - & - & - \\
\hline 2033 & & 83.6 & - & - & - & . & . & . \\
\hline 2034 & & 83.6 & - & - & - & - & - & . \\
\hline 2035 & & 83.7 & - & . & - & . & - & - \\
\hline 2036 & & 83.8 & - & - & - & - & - & - \\
\hline 2037 & & 83.8 & - & - & - & - & - & . \\
\hline 2038 & & 83.9 & - & - & - & - & . & - \\
\hline 2039 & & 83.9 & - & - & - & . & - & - \\
\hline 2040 & & 84.1 & . & . & - & . & . & - \\
\hline
\end{tabular}

aSpent fuel discharges beyond the year 2030 are projected only in the No New Orders case.

Source: Projections derived from the International Nuclear Model and Form RW-859, "Nuclear Fuel Data" (1989). 
Table D3. Projected Average Burnup of Spent Fuel Discharged by U.S. Nuclear Power Plants for Equilibrium Cycles

(Megawattdays Thermal per Metric Ton of initial Heavy Metal)

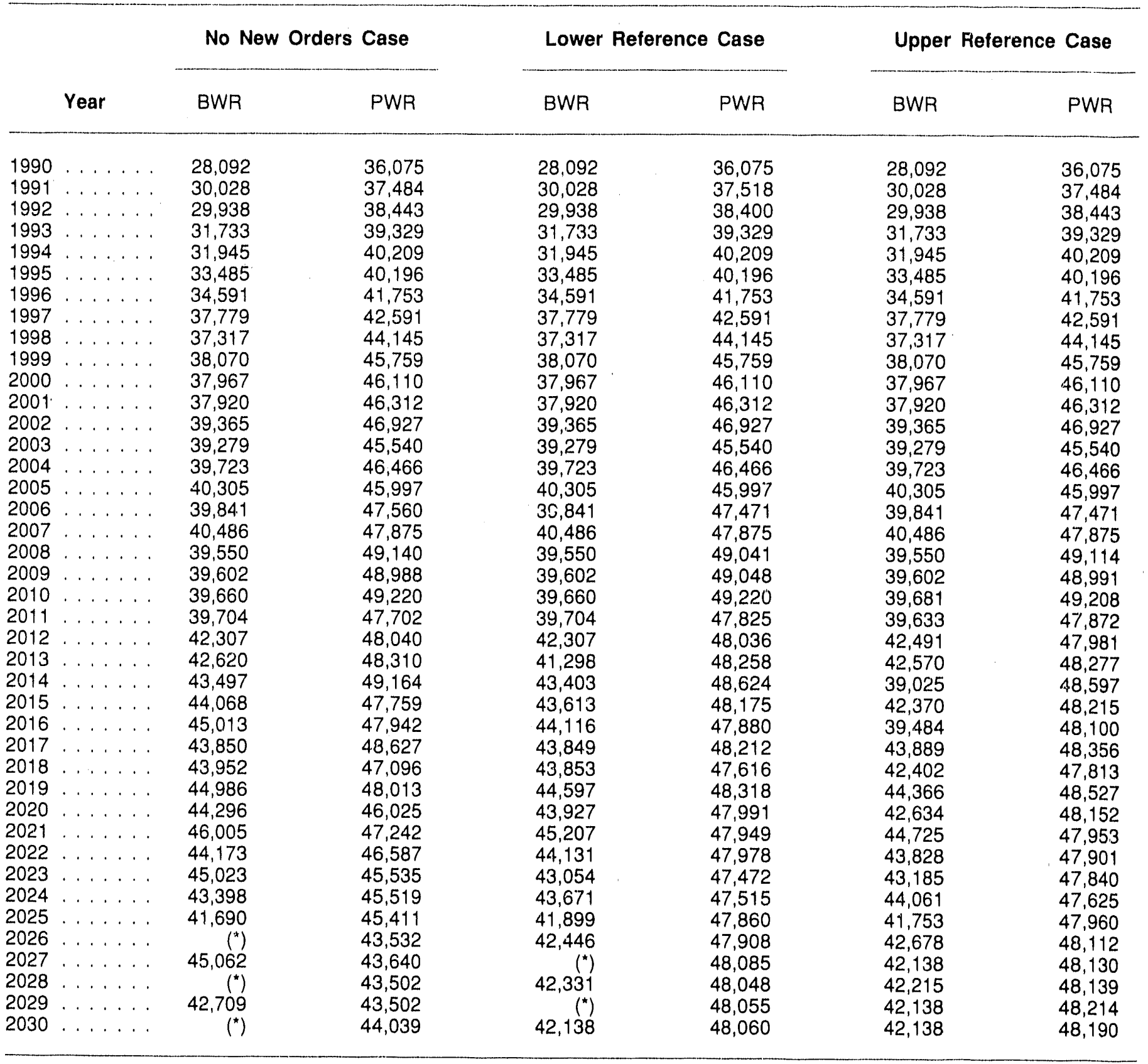

"No spent fuel discharges for year.

Source: Projections derived from the International Nuclear Model and Form RW-859, "Nuclear Fuel Data" (1989). 
Table D4. Projected Average Burnup of Spent Fuel Discharged by U.S. Nuclear Power Plants for All Cycles

(Megawattdays Thermal per Metric Ton of Initial Heavy Metal)

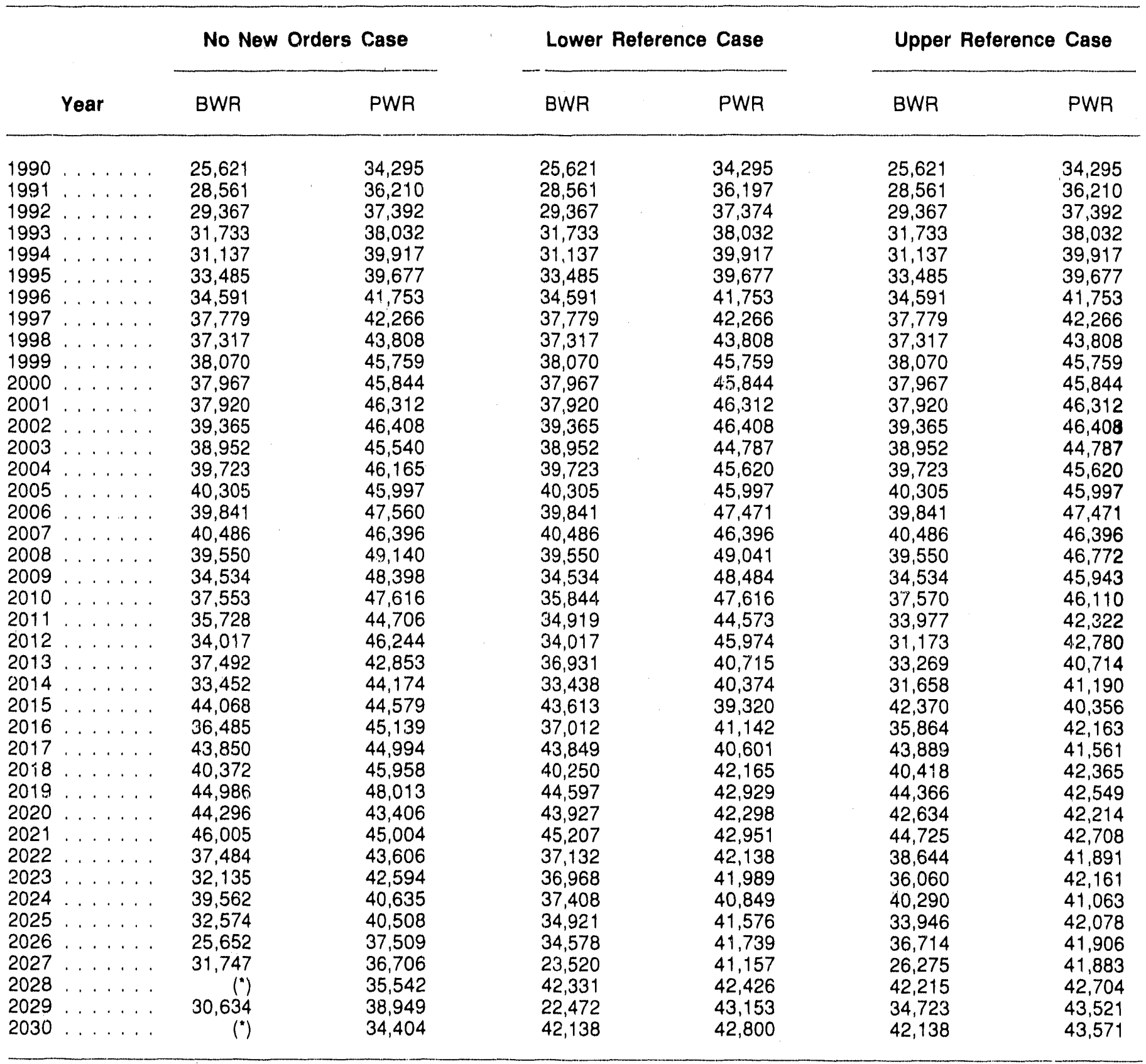

"No spent fuel discharges for year.

Source: Projections derived from the international Nuclear Model and Form RW-859, "Nuclear Fuel Data" (1989). 
Table D5. Projected Spent Fuel Discharges by U.S. Reactors in the No New Orders Case, 1990-2000 (Metric Tons of Initial Heavy Metal)

\begin{tabular}{|c|c|c|c|c|c|c|c|c|c|c|c|}
\hline Unit & 1990 & 1991 & 1992 & 1993 & 1994 & 1995 & 1996 & 1997 & 1998 & 1999 & 2000 \\
\hline Arkansas Nuclear $1 \ldots \ldots$ & 28 & $\cdot$ & 28 & 28 & - & 28 & & 26 & - & 25 & \\
\hline Arkansas Nuclear $2 \ldots \ldots$ & - & 28 & - & 28 & 28 & - & 28 & 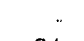 & 26 & & 25 \\
\hline Beaver Valley $1 \ldots \ldots$ & $\therefore$ & 34 & $\therefore$ & 34 & & 32 & $\cdot$ & 31 & $\cdot$ & 29 & · \\
\hline Beaver Valley $2 \ldots \ldots \ldots$ & 31 & 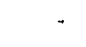 & 31 & - & $3 \uparrow$ & 31 & $\cdot$ & 31 & $\cdot$ & 29 & $\cdot$ \\
\hline Bellefonte $1 \ldots \ldots \ldots$ & $\cdot$ & $\cdot$ & $\cdot$ & $\cdot$ & $\cdot$ & $\cdot$ & - & $\cdot$ & $\cdot$ & - & $\cdot$ \\
\hline Bellefonte $2 \ldots \ldots \ldots$ & i & i & i & 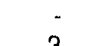 & - & $\dot{2}$ & $\dot{2}$ & $\dot{2}$ & - & & $\dot{0}$ \\
\hline $\begin{array}{l}\text { Blg Rock } 1 \ldots \ldots \ldots \ldots \ldots \\
\text { Braidwood } 1 \ldots \ldots \ldots \ldots\end{array}$ & 3 & $\begin{array}{r}3 \\
36\end{array}$ & $\begin{array}{r}3 \\
36\end{array}$ & 3 & 36 & 3 & $\begin{array}{r}2 \\
36\end{array}$ & 2 & $\begin{array}{r}2 \\
34\end{array}$ & $\begin{array}{r}2 \\
32\end{array}$ & 2 \\
\hline Braldwood $2 \ldots \ldots \ldots$ & 36 & 34 & - & 32 & - & 32 & 32 & . & 30 & $\begin{array}{l}32 \\
28\end{array}$ & . \\
\hline Browns Ferry $1 \ldots \ldots \ldots$ & - & - & - & - & - & 38 & - & 64 & - & 37 & - \\
\hline Browns Ferry $2 \ldots \ldots \ldots$ & - & $\cdot$ & 52 & - & 40 & - & 36 & & 37 & - & . \\
\hline Browns Ferry $3 \ldots \ldots$ & $\dot{-}$ & $\cdot$ & $\dot{x}$ & - & 45 & - & 42 & - & 37 & 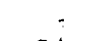 & - \\
\hline Brunswick $1 \ldots \ldots$ & 23 & - & 27 & - & - & 27 & - & 24 & - & 24 & \\
\hline Brunswick $2 \ldots \ldots$ & & 31 & - & 23 & - & & 27 & - & 25 & . & 25 \\
\hline Byron $1 \ldots \ldots \ldots$ & 32. & 30 & - & 32 & - & 32 & 32. & $\therefore$ & 30 & 28 & - \\
\hline$\ldots \ldots \ldots \ldots$ & 36 & $\cdots$ & 37 & 37 & $\therefore$ & 37 & $\cdot$ & 35 & 35 & - & 33 \\
\hline$\ldots \ldots \ldots$ & 41 & & 39 & $\therefore$ & 32 & 39 & - & 35 & 34 & - & 33 \\
\hline Calvert Cliffs $1 \ldots \ldots \ldots$ & $\cdot$ & 36 & $\ddot{2}$ & 34 & & 34 & - & 32 & & 31 & - \\
\hline Calvert Cliffs $2 \ldots \ldots \ldots$ & $\therefore$ & $\therefore$ & 35 & - & 34 & $\dot{n}$ & 34 & - & 32 & $\therefore$ & 30 \\
\hline Catawba $1 \ldots \ldots \ldots$ & 31 & 29 & 32 & - & 32 & 32 & & 31 & & 29 & 28 \\
\hline Catawba $2 \ldots \ldots \ldots$ & 29 & 32 & - & 32 & & 32 & 32 & - & 31 & 29 & - \\
\hline Clinton $1 \ldots \ldots \ldots$ & 40 & 37 & $\cdot$ & 38 & & 38 & 34 & - & 34 & - & 34 \\
\hline Comanche Peak $1, \ldots \ldots$ & - & 26 & 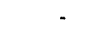 & 26 & 26 & 27 & 26 & 25 & 24 & - & 24 \\
\hline Comanche Peak $2 \ldots \ldots$ & $\dot{-i}$ & $\cdot$ & - & 27 & - & 26 & 26 & 27 & 24 & 24 & 24 \\
\hline Donald C. Cook $1 \ldots$. . . . & 37 & - & 37 & - & 37 & - & 36 & - & 34 & & 32 \\
\hline Donald C. Cook $2 \ldots \ldots$ & 29 & - & 31 & - & 31 & . & 30 & - & 29 & 27 & - \\
\hline Cooper Station $\ldots \ldots \ldots \ldots$ & 31 & - & 25 & 31 & - & - & 25 & 26 & & 24 & - \\
\hline Crystal River $3 \ldots \ldots$ & 36 & - & 36 & - & - & 33 & $\dot{2}$ & 31 & $\cdot$ & 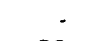 & 29 \\
\hline Davis-Besse $1 \ldots \ldots$ & 29 & - & 28 & - & 28 & - & 28 & - & - & 26 & \\
\hline Diablo Canyon $1 \ldots \ldots$ & - & 31 & 31 & $\cdot$ & 36 & - & 33 & 41 & - & 36 & 34 \\
\hline Diablo Canyon $2 \ldots \ldots$. . . & 34 & 40 & - & 53 & & 29 & 34 & - & 29 & 28 & - \\
\hline Dresden $2 \ldots \ldots \ldots$ & 28 & - & 27 & - & 28 & - & 27 & - & 26 & $\cdot$ & 25 \\
\hline Dresden $3 \ldots \ldots \ldots$ & & 27 & & 27 & - & 27 & . & 26 & 24 & - & 24 \\
\hline Duane Arnold . . . . . . . . . . & 17 & - & 17 & - & 17 & 16 & $\cdot$ & 15 & - & 16 & 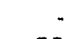 \\
\hline Enrico Fermi $2 \ldots \ldots$ & - & 37 & 31 & - & 35 & 37 & - & 35 & 33 & - & 33 \\
\hline Joseph M. Farley $1 \ldots$. . . & s. & 30 & 30 & - & 30 & 30 & - & 29 & 26 & - & 26 \\
\hline Joseph M. Farley $2 \ldots$. . . & 28 & - & 30 & 30 & - & 30 & 29 & - & 28 & 27 & - \\
\hline James Fitzpatrick . . . . . . . & 28 & - & 37 & - & 36 & - & - & 35 & - & 33 & . \\
\hline Fort Calhoun $\ldots \ldots \ldots$ & 15 & 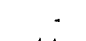 & 16 & 16 & - & 16 & - & 15 & - & 14 & - \\
\hline Ginna ................ & 10 & 11 & 11 & 11 & 11 & 11 & 11 & 11 & 10 & 10 & 10 \\
\hline Grand Gulf $1 \ldots \ldots$ & 50 & $\therefore$ & 49 & - & 49 & 48 & - & 43 & - & 45 & \\
\hline Haddam Neck . . . . . . . . . & - & 19 & & 19 & 21 & & 19 & 18 & - & 17 & 17 \\
\hline Shearon Harris $1 \ldots \ldots$ & - & 24 & 24 & - & 24 & 24 & . & 27 & 23 & - & 23 \\
\hline Edwin 1. Hatch $1 \ldots \ldots$ & 33 & & 33 & & 33 & & 33 & - & 30 & - & 30 \\
\hline Edwin 1. Hatch $2 \ldots \ldots$ & - & 35 & $\dot{0}$ & 33 & - & 33 & - & 28 & - & 30 & $\therefore$ \\
\hline Hope Creek & - & 49 & 46 & $\therefore$ & 43 & - & 41 & & 38 & - & 39 \\
\hline Indian Point 2 & - & 33 & - & 33 & - & 33 & $\cdot$ & 31 & - & 29 & $\cdot$ \\
\hline Indian Point 3 & 33 & - & 38 & $\therefore$ & : & 38 & - & - & - & 35 & - \\
\hline Kewaunee . . & 13 & 13 & 14 & 14 & 14 & 14 & 14 & 14 & 13 & 12 & 12 \\
\hline LaSalle City $1 \ldots \ldots$ & - & 35 & - & 36 & - & 35 & - & 33 & - & 34 & - \\
\hline LaSalle City $2 \ldots \ldots \ldots$ & 39 & $\cdot$ & 36 & - & 38 & & 36 & - & 34 & - & 33 \\
\hline Limerick $1 \ldots \ldots$ & 20 & - & 52 & - & - & 50 & - & - & 47 & . & . \\
\hline$\ldots \ldots \ldots$ & - & - & 47 &. & 52 & - & 48 & $\dot{-}$ & - & 47 & - \\
\hline Maine Yankee . . . . . . . . . . & 26 & $\cdot$ & 26 & 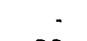 & 26 & 26 & - & 25 & & 23 & . \\
\hline McGuire $1 \ldots \ldots$ & 33 & 32 & - & 32 & 32 & & 32 & - & 30 & 29 & - \\
\hline McGuire $2 \ldots \ldots \ldots$ & 32 & & 32 & 32 & - & 32 & - & 31 & 30 & & 29 \\
\hline Millstone $1 \ldots \ldots \ldots$ & - & 35 & $\dot{-}$ & 35 & - & 35 & - & 31 & - & 32 & - \\
\hline Millstone $2 \ldots \ldots \ldots$ & 29 & - & 35 & - & 34 & - & 33 & . & - & 32 & . \\
\hline Millistone $3 \ldots \ldots$ & 41 & $\dot{8}$ & 44 & - & 45 & - & & 44 & - & 41 & - \\
\hline Monticello $\ldots \ldots \ldots \ldots$ & - & 22 & - & 22 & - & 22 & 22 & - & 20 & - & 20 \\
\hline
\end{tabular}

See footnote at end of table. 
Table D5. Projected Spent Fuel Discharges by U.S. Reactors in the No New Orders Case, 1990-2000 (Continued)

(Metric Tons of Initial Heavy Metal)

\begin{tabular}{|c|c|c|c|c|c|c|c|c|c|c|c|}
\hline Unit & 1990 & 1991 & 1092 & 1993 & 1994 & 1995 & 1996 & 1997 & 1998 & 1999 & 2000 \\
\hline Nine Mlle Point $1 \ldots \ldots$ & & & ३3 & - & 31 & - & 32 & $\therefore$ & 28 & - & 28 \\
\hline NIne Mile Polnt $2 \ldots . . .$. & 33 & 45 & - & 37 & & 38 & & 34 & $\therefore$ & 35 & \\
\hline North Anna $1 \ldots \ldots$ & & 34 & $\dot{-}$ & 32 & 30 & - & 30 & $\therefore$ & 28 & - & 27 \\
\hline North Anna $2 \ldots \ldots$ & 34 & - & 30 & - & 30 & 30 & $\cdot$ & 28 & & 28 & $\therefore$ \\
\hline Oconee $1 \ldots \ldots \ldots \ldots$ & 24 & 24 & & 24 & $\therefore$ & 24 & - & 24 & 23 & - & 21 \\
\hline$\ldots \ldots \ldots$ & 24 & - & 24 & - & 24 & 24 & - & 23 & $\cdot$ & 21 & 21 \\
\hline Ocones $3 \ldots \ldots \ldots$ & $\therefore$ & 2.4 & 24 & - & 24 & - & 24 & 23 & - & 21 & $\cdot$ \\
\hline Oyster Creok $1 \ldots \ldots$ & 23 & - & - & 32 & - & - & 30 & - & - & 28 & - \\
\hline Pálisades ............ & 24 & $\therefore$ & 24 & - & $\because$ & 22 & & 23 & - & 20 & - \\
\hline Palo Verde $1 \ldots \ldots \ldots$ & - & 41 & 41 & 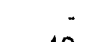 & 41 & - & 41 & 39 & - & 36 & 36 \\
\hline Palo Verde 2 & 40 & 40 & $\cdot$ & 40 & 40 & 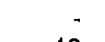 & 39 & - & 37 & 35 & - \\
\hline Palo Verde 3 & - & 40 & 40 & $\therefore$ & 40 & 40 & $\therefore$ & 37 & 35 & - & 35 \\
\hline Peachbottom $2 \ldots \ldots \ldots$ & - & 39 & - & 52 & $\therefore$ & - & 50 & - & - & 47 & - \\
\hline Peachbottom $3 \ldots \ldots$ & & 48 & & - & 42 & - & & 51 & - & $\dot{-}$ & 48 \\
\hline Perry $1 \ldots \ldots \ldots$ & 48 & - & 45 & - & 47 & 48 & - & 44 & - & 43 & $\therefore$ \\
\hline Pllgrim $1 \ldots \ldots \ldots$ & 35 & $\therefore$ & - & 36 & - & - & 34 & - & . & - & 33 \\
\hline Point Beach $1 \ldots \ldots \ldots$ & 13 & 12 & 12 & 12 & 12 & 12 & 12 & 12 & 11 & 10 & 10 \\
\hline Point Beach $2 \ldots \ldots \ldots \ldots$ & 12 & 12 & 12 & 12 & 12 & 12 & 11 & 11 & 11 & 11 & 10 \\
\hline Prairle Island $1 \ldots \ldots \ldots$ & 17 & 21 & 17 & $=$ & 17 & 17 & - & 17 & 15 & - & 15 \\
\hline Prairie Island $2 \ldots \ldots \ldots$ & 19 & - & 18 & 17 & 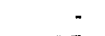 & 17 & 16 & - & 16 & - & 15 \\
\hline Quad Clties $1 \ldots \ldots \ldots$ & 26 & - & 16 & & 25 & 26 & . & 24 & - & 24 & 23 \\
\hline Quad Clites $2 \ldots \ldots \ldots$ & 30 & 26 & - & 27 & $\cdot$ & 27 & 24 & - & 24 & $\cdot$ & 24 \\
\hline H.B. Robinson $2 \ldots \ldots \ldots$ & 21 & - & 21 & 27 & & 21 & - & 20 & 19 & i & 19 \\
\hline Rlver Bend $1 \ldots \ldots$ & 37 & - & 38 & 38 & - & 38 & - & 31 & 34 & - & 34 \\
\hline Salem $1 \ldots \ldots \ldots$ & 41 & - & 39 & - & 39 & $\cdot$ & 37 & $\dot{-}$ & 32 & $\cdot$ & 32 \\
\hline$\ldots \ldots \ldots \ldots$ & 39 & - & 34 & $\therefore$ & 39 & 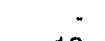 & - & 38 & 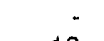 & - & 34 \\
\hline San Onotre $1 \ldots \ldots$ & 19 & - & - & 19 & - & 19 & - & & 18 & - & 17 \\
\hline San Onofre $2 \ldots \ldots \ldots$ & & 44 & & 44 & $\therefore$ & 44 & $\dot{2}$ & 42 & - & - & 38 \\
\hline San Onofre $3 \ldots \ldots$ & 42 & " & 44 & - & 44 & - & 44 & - & 41 & - & 39 \\
\hline Seabrook $1 \ldots \ldots \ldots$ & & - & 30 & 30 & 30 & 30 & 30 & 28 & - & 27 & 26 \\
\hline Sequoyah $1 \ldots \ldots \ldots$ & 31 & - & 29 & - & 29 & - & 29 & - & - & 26 & - \\
\hline Sequoyah $2 \ldots \ldots \ldots \ldots$ & 33 & $=$ & 31 & $\cdot$ & - & 29 & - & 28 & - & 26 & - \\
\hline South Texas $1 \ldots \ldots$ & 26 & 45 & 37 & - & 38 & - & 37 & - & 36 & 34 & - \\
\hline South Texas $2 \ldots \ldots$ & 32 & - & 43 & 38 & $\cdot$ & 39 & $\cdot$ & 34 & - & 35 & 33 \\
\hline St. Lucle $1 \quad \ldots \ldots \ldots \ldots$. & 39 & 28 & $\therefore$ & 35 & $\therefore$ & 34 & - & 36 & - & 32 & $\therefore$ \\
\hline St. Lucie $2 \ldots \ldots \ldots$ & 29 & - & 36 & - & 37 & - & 37 & - & 35 & - & 33 \\
\hline Summer $1 \ldots \ldots \ldots$ & 36 & 32 & & 32 & 32 & - & 31 & - & 29 & 28 & - \\
\hline Surry $1 \ldots \ldots \ldots$ & 26 & - & 26 & - & 24 & - & 24 & - & 23 & - & 22 \\
\hline Surry $2 \ldots$ & - & 30 & $\cdot$ & 24 & - & 24 & 24 & - & 23 & $\cdot$ & 22 \\
\hline Susquehanna $1 \ldots \ldots \ldots$ & 38 & & 38 & 38 & - & 38 & 33 & - & 34 & - & 35 \\
\hline Susquehanna $2 \ldots \ldots \ldots$ & - & 42 & 39 & - & 39 & - & 38 & 34 & - & 35 & 35 \\
\hline Three Mile Island $1 \ldots \ldots$ & 35 & & 41 & - & 36 & & & 34 & - & & 33 \\
\hline Trojan $\ldots \ldots \ldots \ldots \ldots$ & 21 & 20 & 20 & 30 & 30 & $\ddot{n}$ & 29 & 28 & 26 & 26 & 26 \\
\hline Turkey Point 3 & 26 & - & 22 & 20 & - & 20 & $\cdot$ & 19 & - & 18 & . \\
\hline Turkey Point 4 & 22 & - & 20 & & 20 & & 20 & 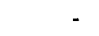 & 19 & & 18 \\
\hline Vogtle $1 \ldots \ldots \ldots \ldots$ & 39 & - & 35 & 37 & - & 35 & - & 34 & - & 32 & $\therefore$ \\
\hline Vogtle 2 & 37 & . & 37 & & 35 & - & 35 & & 34 & - & 32 \\
\hline Vermont Yankee $1 \ldots \ldots$ & 23 & - & 23 & 23 & - & 23 & . & 22 & - & 21 & 21 \\
\hline Washington Nuclear $2 \ldots \ldots$ & 25 & 24 & 24 & 24 & 23 & 23 & . & 22 & 21 & 21 & 21 \\
\hline Waterford $3 \ldots \ldots \ldots$ & - & 35 & 35 & & 35 & 35 & - & 33 & - & 33 & 31 \\
\hline Watts Bar $1 \ldots \ldots \ldots$ & - & $\cdot$ & - & - & 31 & 29 & - & 28 & 28 & - & 27 \\
\hline Watts Bar $2 \ldots \ldots \ldots \ldots$ & - & - & & - & - & - & . & 30 & 28 & 26 & \\
\hline Woli Creek $1 \ldots \ldots$ & 37 & - & 39 & $\cdot$ & 39 & - & 38 & - & 36 & 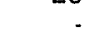 & 34 \\
\hline Yankes-Rowe $1 \ldots \ldots$ & 8 & - & 9 & - & 8 & 9 & - & 8 & - & 8 & 18 \\
\hline Zlon $1 \ldots \ldots \ldots$ & - & 35 & - & 35 & 35 & - & 35 & - & 33 & - & 31 \\
\hline Zion $2 \ldots \ldots \ldots \ldots$ & 35 & 35 & - & 33 & - & 33 & $\cdot$ & 31 & - & 29 & 29 \\
\hline $\begin{array}{l}\text { BWR Subtotal } \ldots \ldots \ldots \\
\text { PWR Subtotal } \ldots \ldots\end{array}$ & $\begin{array}{r}630 \\
1,568\end{array}$ & $\begin{array}{r}534 \\
1,067\end{array}$ & $\begin{array}{r}738 \\
1,573\end{array}$ & $\begin{array}{r}555 \\
1,091\end{array}$ & $\begin{array}{r}625 \\
1,439\end{array}$ & $\begin{array}{r}670 \\
1,298\end{array}$ & $\begin{array}{r}617 \\
1,167\end{array}$ & $\begin{array}{r}62.3 \\
1,297\end{array}$ & $\begin{array}{r}529 \\
1,197\end{array}$ & $\begin{array}{r}579 \\
1,229\end{array}$ & $\begin{array}{r}569 \\
1,192\end{array}$ \\
\hline 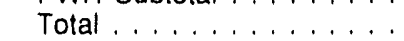 & 2,199 & 1,601 & 2,311 & 1,646 & 2,064 & 1,968 & 1,783 & 1,920 & 1,719 & 1,808 & 1,762 \\
\hline
\end{tabular}

Source: Projections derived from the International Nuclear Model and Form AW-859, "Nuclear Fuel Data" (1989). 
Table D6. Projected Spent Fuel Discharges by U.S. Reactors in the No New Orders Case, 2001-2010 (Metric Tons of Initial Heavy Metal)

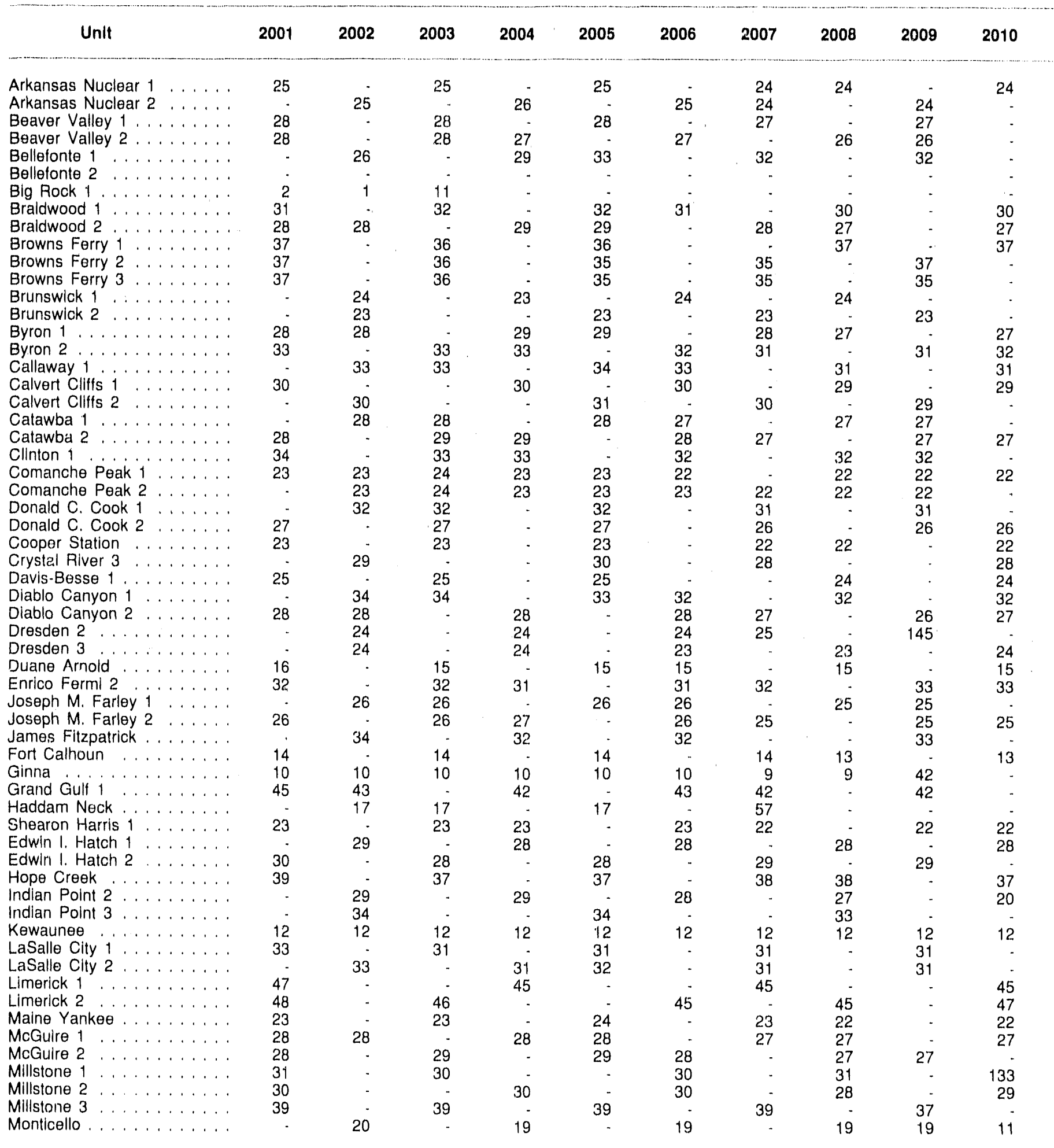

See footnote at end of table. 
Table D6. Projected Spent Fuel Discharges by U.S. Reactors in the No New Orders Case, 2001-2010 (Continued)

(Metric Tons of Inltial Heavy Metal)

\begin{tabular}{|c|c|c|c|c|c|c|c|c|c|c|}
\hline Unit & 2001 & 2002 & 2003 & 2004 & 2005 & 2006 & 2007 & 2008 & 2009 & 2010 \\
\hline NIne Mile Point $1 \ldots \ldots$ & . & 27 & . & 26 & . & 27 & . & 27 & 91 & - \\
\hline Nine Mile Polnt $2 \ldots . .$. & 36 & 34 & . & 34 & - & 33 & - & 33 & - & 33 \\
\hline North Anna $1 \ldots \ldots$ & & 27 & & 27 & & 26 & 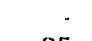 & 25 & 25 & - \\
\hline North Anná $2 \ldots$ & 27 & 27 & . & 27 & . & 26 & 25 & - & 25 & - \\
\hline Ocones $1 \ldots \ldots$ & - & 21 & 21 & & 21 & 20 & & 20 & - & 20 \\
\hline Ocones $2 \ldots \ldots \ldots \ldots$ & i & 21 & - & 22 & 21 & & 20 & 20 & .. & 20 \\
\hline$\ldots \ldots \ldots$ & 21 & 21 & . & 22 & - & 21 & 20 & - & 20 & 20 \\
\hline Oyster Creak $1 \ldots \ldots$ & & 28 & & & 27 & - & & 28 & 100 & - \\
\hline Pallisades . . . . . . . . . . & . & 21 & - & 2.1 & - & . & 20 & - & 19 & - \\
\hline Palo Verde $1 \ldots \ldots$ & $\cdot$ & 36 & 37 & - & 37 & 36 & $\cdot$ & 34 & 34 & - \\
\hline$\ldots \ldots \ldots$ & 35 & 35 & & 35 & 35 & & 34 & 33 & - & 33 \\
\hline Palo Verde 3 & 35 & $\dot{-}$ & 35 & 35 & & 35 & 33 & $\therefore$ & 33 & 34 \\
\hline Peachbottom $2 \ldots \ldots$ & & 47 & & & 45 & & & 46 & - & \\
\hline Peachbottom $3 \ldots \ldots$ & & & 46 & & 45 & & . & 45 & . & - \\
\hline$\ldots \ldots \ldots$ & 43 & $\cdot$ & 42 & 41 & & 41 & $\cdot$ & 40 & $\cdot$ & 41 \\
\hline$\ldots \ldots \ldots$ & . & & 31 & & - & 31 & - & . & 31 & - \\
\hline Point Beach 1 & 10 & 11 & 11 & 10 & 10 & 11 & 10 & 10 & 10 & 52 \\
\hline Point Buach 2 & 10 & 11 & 11 & 11 & 11 & 10 & 10 & 10 & 10 & 9 \\
\hline Prairie Island $1 \ldots \ldots \ldots$ & 15 & - & 15 & 15 & 15 & & 15 & 14 & & 14 \\
\hline Prairie Island $2 \ldots \ldots \ldots$ & 15 & - & 15 & 15 & . & 15 & 14 & 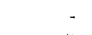 & 14 & 14 \\
\hline Quad Cities 1 & & 23 & 22 & - & 22 & . & 22. & 23 & & 23 \\
\hline Quad Cities 2 & 25 & & 23 & - & 23 & 23 & . & 24 & 24 & - \\
\hline H.B. Robirison $2 \ldots \ldots$ & - & 19 & 19 & & 19 & 18 & & 18 & 15 & 67 \\
\hline River Bend $1 \ldots \ldots$ & . & 33 & 32 & & 32 & 32. & - & 31 & . & 32 \\
\hline Salam $1 \ldots \ldots \ldots$ & - & 32 & $\cdot$ & 32 & - & 31 & & 30 & - & 30 \\
\hline$\ldots \ldots \ldots$ & & 33 & - & 34 & & & 33 & & 32 & - \\
\hline San Onofre 1 & - & - & 17 & - & 17 & & 58 & - & & 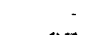 \\
\hline San Onotre $? \ldots \ldots \ldots$ & . & 38 & $\cdot$ & 39 & - & 39 & & 37 & & 37 \\
\hline San Onotre $3 \ldots \ldots$ & - & $\therefore$ & 39 & & 39 & & 37 & & 37 & \\
\hline Seabrook $1 \ldots \ldots \ldots$ & 26 & 26 & 26 & 20 & 26 & 25 & 25 & 25 & 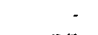 & 25 \\
\hline Sequoyah $1 \ldots \ldots \ldots$ & 26 & - & 26 & & 26 & & 25 & & 25 & \\
\hline Sequoyah $2 \ldots \ldots \ldots$ & 26 & . & $\cdots$ & 26 & . & 25 & . & 25 & & 25 \\
\hline South Texas $1 \ldots \ldots$ & 33 & . & 33 & 33 & & 32 & . & 31 & 31 & - \\
\hline South Texas $2 \ldots \ldots \ldots$ & & 33 & & 33 & 33 & . & 32 & ". & 31 & 32 \\
\hline St. Lucie $1 \ldots \ldots \ldots \ldots$ & 31 & - & 31 & . & 31 & - & 31 & - & 29 & 30 \\
\hline St. Lucie $2 \ldots \ldots \ldots$ & $\cdot$ & 33 & - & 33 & - & 32. & - & 31 & & \\
\hline Surnmer $1 \ldots \ldots \ldots$ & 28 & 28 & . & 28 & 27 & . & 27 & . & 26 & 27 \\
\hline Surry $1 \ldots \ldots \ldots$ & - & 21 & & 21 & - & 21 & 21 & . & 20 & \\
\hline Surry $2 \ldots \ldots \ldots$ & - & 22 & . & 22 & - & 21 & . & 20 & & 20 \\
\hline Susquehanna $1 \ldots \ldots$ & 34 & & 33 & 33 & & 33 & 32 & - & 32 & 32 \\
\hline Susquehanna $2 \ldots \ldots \ldots$ & - & 34 & . & 33 & 33 & - & 34 & 35 & . & 34 \\
\hline Three Mile Island $1 \ldots \ldots$ & - & 32 & - & . & 32 & & 31 & . & - & 30 \\
\hline Trojan $\ldots \ldots \ldots \ldots$ & 26 & - & 27 & 26 & 26 & 25 & 25 & 25 & 25 & 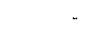 \\
\hline Turkey Point $3 \ldots \ldots$ & 18 & - & 18 & 18 & & 18 & 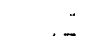 & 17 & . & 17 \\
\hline Turkey Point $4 \ldots \ldots$ & - & 18 & 18 & & 18 & & 17 & & 17 & 17 \\
\hline Vogtle $1 \ldots \ldots \ldots$ & 31 & 31 & - & 31 & & 31 & & 30 & 29 & \\
\hline Vogtle $2 \ldots \ldots \ldots$ & 31 & - & 31 & - & 31 & - & 30 & 29 & $\therefore$ & 30 \\
\hline Vermont Yankee $1 \ldots \ldots$ & - & 2.1 & & 20 & 20 & - & 20 & - & 21 & 21 \\
\hline Washington Nuclear $2 \ldots$ & 20 & 20 & 20 & 20 & & 20 & 20 & 20 & 20 & 20 \\
\hline Waterford $3 \ldots \ldots \ldots$ & $\dot{-}$ & 31 & 31 & $\therefore$ & 31 & 30 & & 29 & 29 & \\
\hline Watts Bar $1 \ldots \ldots \ldots$ & 26 & & 26 & 26 & & 26 & 25 & - & 25 & 25 \\
\hline Watts Bar $2 \ldots \ldots \ldots$ & 26 & 26 & 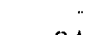 & 26 & 25 & . & 25 & 25 & - & 25 \\
\hline Wolf Creek $1 \ldots \ldots$ & 34 & $\cdot$ & 34 & - & 34 & $\cdot$ & 33 & . & 32 & \\
\hline Yankee-Rowe $1 \ldots \ldots$ & & & & $\cdot$ & - & $\therefore$ & & - & - & \\
\hline Zion $1 \ldots \ldots \ldots \ldots$ & 31 & 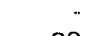 & 31 & - & 31 & 30 & . & 29 & . & 29 \\
\hline Zion $2 \ldots \ldots$ & . & 29 & “ & 29 & 28 & $\cdot$ & 28 & & 27 & 28 \\
\hline BWF Subtotal . . . . . . . . & 648 & 521 & 643 & 540 & 543 & 584 & 515 & 666 & 810 & 667 \\
\hline PWR Subtotal $\ldots \ldots \ldots$ & 1,157 & 1,206 & 1,173 & 1,188 & 1,314 & 1,126 & 1,317 & 1.112 & 1,160 & 1,261 \\
\hline Total ............... & 1,805 & 1,727 & 1,817 & 1,729 & 1,857 & 1,710 & 1,831 & 1,778 & 1,970 & 1,928 \\
\hline
\end{tabular}

Source: Projections derived from the International Nuclear Model and Form RW-859, "Nuclear Fuel Data" (1989). 
Table D7. Projected Spent Fuel Discharges by U.S. Reactors In the No New Orders Case, 2011-2020 (Metric Tons of Initial Heavy Metal)

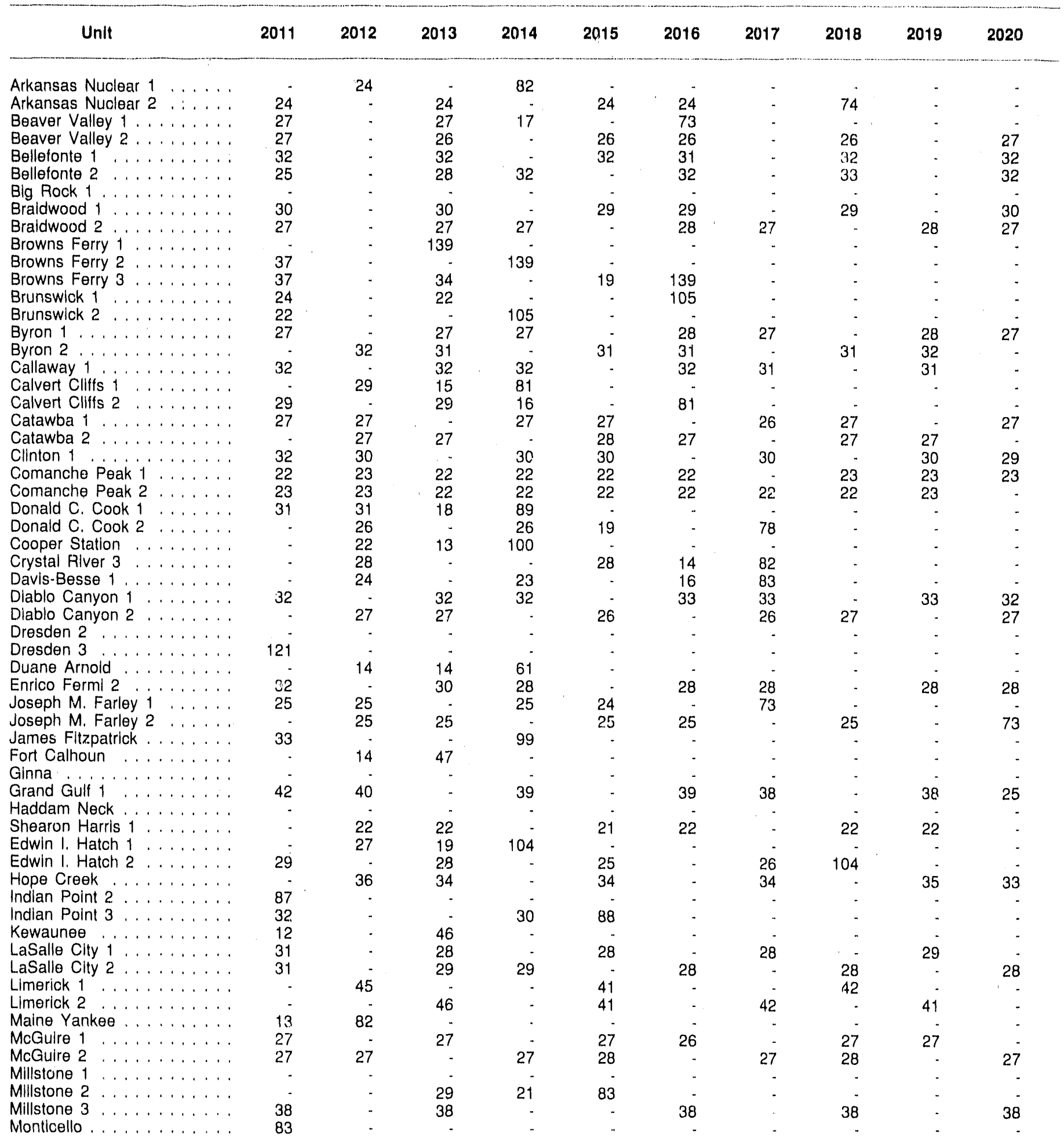

See foutnote at end of table. 
Table D7. Projected Spent Fuel Discharges by U.S. Reactors in the No New Orders Case, 2011-2020 (Continued)

(Metric Tons of Initial Heavy Metal)

\begin{tabular}{|c|c|c|c|c|c|c|c|c|c|c|}
\hline Unlt & 2011 & 2012 & 2013 & 2014 & 2015 & 2016 & 2017 & 2018 & 2019 & 2020 \\
\hline Nine Mile Point $1, \ldots \ldots$ & . & .. & . & . & & - &. & & & \\
\hline Nine Mlle Point $2 \ldots \ldots$ & 32 & - & 31. & - & 30 & - & 31 & 31 & . & 30 \\
\hline North Anna $1 \ldots \ldots$ & 25 & . & 25 & . & - & 73 & . & . & . & .. \\
\hline North Anna $2 \ldots . . .$. & 25 & 25 & - & 26 & - & 26 & 26 & - & 20 & 73 \\
\hline Ocones $1 \ldots \ldots$ & 15 & · & 82 & - & & - & $\cdot$ & $\cdot$ & - & - \\
\hline Ocones $2 \ldots \ldots \ldots$ & 16 & - & 82 & - & . & . & . & - & . & . \\
\hline Ocones $3 \ldots \ldots$ & - & 16 & - & 82 & - & - & - & - & & . \\
\hline Oyster Creek $1 \ldots \ldots \ldots$ & - & . & . & . & - & . & . & - & . & - \\
\hline Palisades $\ldots \ldots \ldots \ldots \ldots$ & 82 & - & . & . & . & . & - & . & . & - \\
\hline Palo Verde $1 \ldots \ldots \ldots$ & 35 & 35 & 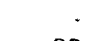 & 34 & 34 & - & 34 & 34 & - & 35 \\
\hline Palo Verde $2 \ldots \ldots \ldots$ & 34 & . & 33 & 34 & - & 33 & 33 & . & 33 & 34 \\
\hline Palo Verde 3 & - & 34 & 33 & - & 33 & 33 & . & 34 & 34 & . \\
\hline Peachbottom $2 \ldots \ldots$ & 45 & 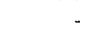 & 135 & & & . & . & . & . & . \\
\hline Peachbottom $3 \ldots \ldots$ & 46 & - & . & 135 & & . & . & . & . & . \\
\hline Perry $1 \ldots \ldots \ldots$ & 40 & . & 38 & . & 37 & . & 37 & 38 & . & 37 \\
\hline Pilgrim $1 \ldots \ldots \ldots$ & - & 103 & $\cdot$ & . & - & - & & - & . & . \\
\hline Point Beach $1 \ldots \ldots$ & . & . & . & . & & . & . & . & . & . \\
\hline Point Beaoh $2 \ldots \ldots \ldots$ & 44 & .. & . & & & . & . & . & . & . \\
\hline Prairie Island $1 \ldots \ldots$ & 12 & . & 43 & 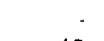 & - & - & . & - & . & - \\
\hline Prairle Island $2 \ldots \ldots \ldots$ & & 14 & 14 & 43 & . & . & & .. & & - \\
\hline Quad Clites $1 \ldots \ldots$ & 128 & & $\cdot$ & $\cdot$ & & . & . & . & . & . \\
\hline Quad Cities 2 & . & 128 & - & . & . & - & - & - & . & - \\
\hline H.B. Robinson $2 \ldots \ldots$ & & & & . & . & . & . & & & 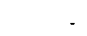 \\
\hline Fiver Bend $1 \ldots \ldots$ & 31 & . & 30 & 29 & & 29 & - & 29 & 28 & . \\
\hline Salern $1 \ldots \ldots$ & . & 31 & 19 & & . & 89 & - & - & - & . \\
\hline Salem $2 \ldots \ldots \ldots$ & - & 32 & 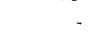 & 32 & - & 31 & - & 26 & . & 89 \\
\hline San Onotre 1 & . & . & - & & . & & . & & . & \\
\hline San Onolre 2 & & 37 & . & 37 & & 37 & . & 38 & . & 37 \\
\hline San Onofre 3 & 37 & & 37 & & 36 & & 37 & & 38 & \\
\hline Seabrook 1 & 25 & 25 & 25 & 25 & 24 & 24 & 24 & 25 & 25 & 25 \\
\hline Sequoyah 1 & & 25 & . & 25 & - & 24 & & 25 & . & 89 \\
\hline Sequoyah 2 & & 25 & - & 25 & . & 25 & & . & 25 & . \\
\hline South Texas 1 & 31 & 32 & - & 31 & - & 31 & 31 & . & 32 & \\
\hline South Texas $2 \ldots \ldots$ & . & 32 & 32 & & 31 & & 31 & 31 & . & 32 \\
\hline St. Lucie $1 \ldots \ldots \ldots$ & - & 30 & - & 30 & & 83 & $\cdot$ & & . & . \\
\hline St. L_ucie $2 \ldots \ldots \ldots \ldots$ & 31 & & 31 & & 31 & & 31 & . & 32 & - \\
\hline Surnmer $1 \ldots \ldots \ldots$ & - & 27 & 26 & & 26 & 26 & . & 26 & 27 & 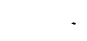 \\
\hline Surry $1 \ldots \ldots \ldots$ & - & 72 & $\therefore$ & . & - & - & & . & - & - \\
\hline$\ldots \ldots \ldots$ & 21 & & 72. & . & - & . & . & . & .. & . \\
\hline Susquehanna $1 \ldots \ldots \ldots$ & . & 31 & 30 & & 30 & 30 & . & 29 & 29 & 15 \\
\hline Susquehanna $2 \ldots \ldots$ & . & 33 & 31 & & 30 & 30 & - & 31 & . & 30 \\
\hline Three Mile Island $1 \ldots .$. & . & 30 & & 82 & & . & . & & . & . \\
\hline$\ldots \ldots \ldots$ & 25 & 25 & 25 & . & 90 & . & . & .. & & . \\
\hline Turkey Point $3 \ldots . . .$. & . & 72 & & . & - & - & . & - & & - \\
\hline Turkey Point $4 \ldots \ldots$ & & 10 & 72 & . & & . & & & . & \\
\hline Vogtle $1 \ldots \ldots \ldots$ & 30 & $\cdot$ & 30 & 30 & . & 30 & & 30 & . & 30 \\
\hline Vogtle $2 \ldots \ldots \ldots$ & . & 30 & & 29 & 29 & - & 29 & - & 30 & \\
\hline Vermont Yankese $1 \ldots$ & 10 & 66 & & & - & - & - & - & - & \\
\hline Washington Nuclear $2 \ldots$ & 20 & 19 & 19 & 18 & 18 & 18 & 18 & 18 & .. & 28 \\
\hline Waterford $3 \ldots \ldots$ & 30 & & 30 & 30 & . & 29 & 29 & & 29 & 30 \\
\hline Watts Bar $1 \ldots \ldots$ & - & 25 & 25 & & 25 & 24 & & 24 & 25 & \\
\hline$\ldots \ldots \ldots$ & 25 & . & 25 & 24 & & 24 & 24 & 3 & 25 & 25 \\
\hline Wolf Creek $1 \ldots . . . .$. & 33 & & 33 & 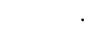 & 34 & . & 33 & & 33 & 33 \\
\hline Yankes-Rowe $1 \ldots . . .$. & - & & & & 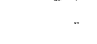 & . & 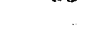 & . & . & \\
\hline Zion $1 \ldots \ldots \ldots$ & 29 & & 88 & - & - & . & . & . & & , \\
\hline ZIon $2 \ldots \ldots \ldots$ & & $\cdot$ & 88 & & & & . & $\cdot$ & $\cdot$ & \\
\hline BWR Subtotal . . . . . . . & 905 & 593 & 749 & 915 & 364 & 446 & 311 & 349 & 258 & 284 \\
\hline PWA Subtotal ......... & 1,281 & 1,200 & 1,679 & 1,277 & 1,002 & 1,304 & 897 & 781 & 681 & 953 \\
\hline Total .............. & 2,186 & 1,793 & 2,428 & 2.192 & 1,366 & 1,749 & 1,208 & 1,130 & 939 & 1,237 \\
\hline
\end{tabular}

Source: Projections derived from the Iriternational Nuclear Model and Form RW-859, "Nuclear Fuel Data" (1989). 
Table D8. Projected Spent Fuel Discharges by U.S. Reactors in the No New Orders Case, 2021-2030 (Metric Tons of Initial Heavy Metal)

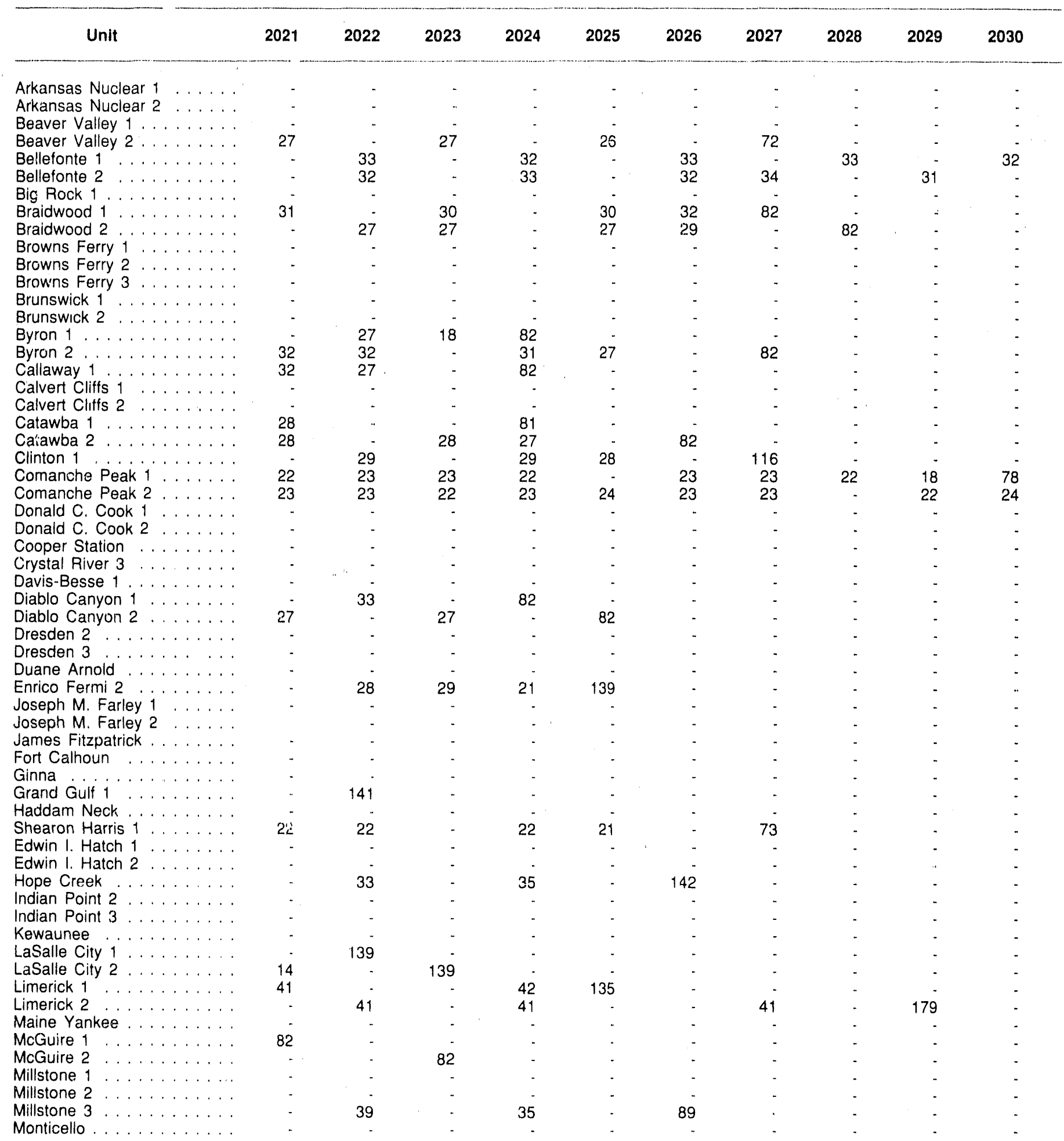

See footnote at end of table. 
Table D8. Projected Spent Fuel Discharges by U.S. Reactors in the No New Orders Case, 2021-2030 (Continued)

(Metric Tons of Initial Heavy Metal)

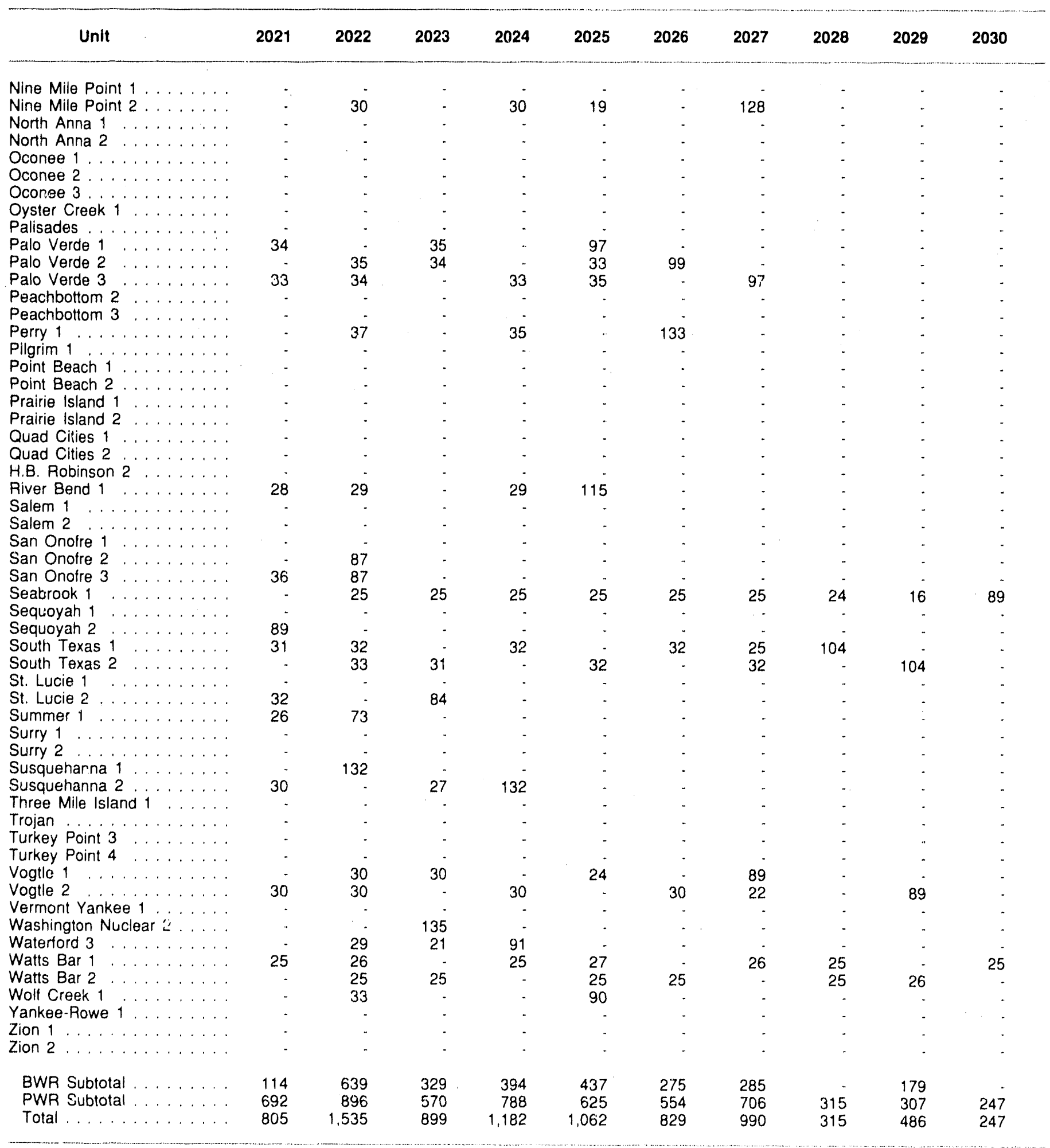

Source: Projections derived from the International Nuclear Model and Form RW-859, "Nuclear Fuel Data" (1989). 
Table D9. Projected Spent Fuel Discharges by U.S. Reactors in the No New Orders Case, 2031-2040 (Metric Tons of Initial Heavy Metal)

\begin{tabular}{|c|c|c|c|c|c|c|c|c|c|c|}
\hline Unit & 2031 & 2032 & 2033 & 2034 & 2035 & 2036 & 2037 & 2038 & 2039 & 2040 \\
\hline Arkansas Nuclear $1 \ldots \ldots$ & - & $\cdot$ & - & - & - & - & - & - & - & - \\
\hline Arkansas Nuclear $2 \ldots \ldots$ & - & - & $\cdot$ & - & $\cdot$ & - & - & - & - & - \\
\hline Beaver Valley $1 \ldots \ldots \ldots$. & - & - & - & - & - & - & - & - & - & . \\
\hline Beaver Valley $2 \ldots . . . .$. & $\dot{0}$ & $\cdot$ & - & - & - & - & - & - & - & - \\
\hline Bellefonte $1 \ldots \ldots \ldots$ & 33 & - & 36 & - & 32 & - & 31 & 32 & 24 & 93 \\
\hline Bellefonte $2 \ldots \ldots \ldots$ & 32 & - & 34 & - & 34 & 31 & - & 31 & - & 126 \\
\hline Big Rock $1 \ldots \ldots \ldots$ & - & - & - & - & - & $\cdot$ & - & - & - & - \\
\hline Braidwood $1 \ldots \ldots$ & - & - & - & - & . & - & - & - & - & - \\
\hline Braidwood $2 \ldots \ldots \ldots$ & - & $\cdot$ & - & - & $\cdot$ & - & - & - & - & - \\
\hline Browns Ferry $1 \ldots \ldots \ldots$ & - & - & - & - & - & . & - & - & - & - \\
\hline Browns Ferry $2 \ldots \ldots \ldots$ & - & - & - & - & - & - & - & . & . & - \\
\hline Browns Ferry $3 \ldots \ldots \ldots$ & $\cdot$ & - & - & - & - & - & - & - & - & - \\
\hline Brunswick $1 \ldots \ldots \ldots$ & - & - & - & - & - & - & - & - & - & - \\
\hline Brunswick $2 \ldots \ldots \ldots$ & . & - & - & - & - & - & - & - & - & - \\
\hline Byron $1 \ldots \ldots \ldots$ & - & - & - & - & - & - & - & - & - & - \\
\hline Byron $2 \ldots \ldots \ldots$ & - & - & - & - & - & - & - & - & - & - \\
\hline Callaway $1 \ldots \ldots \ldots$ & . & - & - & - & - & - & - & - & . & - \\
\hline Calvert Cliffs $1 \ldots \ldots \ldots$ & - & $\therefore$ & - & - & - & - & - & . & . & - \\
\hline Calvert Cliffs $2 \ldots \ldots \ldots$ & - & . & - & - & - & - & - & - & - & - \\
\hline Catawba $1 \ldots \ldots \ldots$ & - & - & - & - & - & - & - & - & - & - \\
\hline Catawba $2 \ldots \ldots \ldots$ & - & - & - & - & - & - & - & - & - & - \\
\hline Clinton $1 \ldots \ldots \ldots$ & - & - & - & . & - & - & -. & - & - & - \\
\hline Comanche Peak $1 \ldots \ldots$. & - & - & - & - & - & - & - & - & . & - \\
\hline Comanche Peak $2 \ldots \ldots$ & 26 & 78 & - & - & - & - & - & - & - & . \\
\hline Donald C. Cook $1 \ldots \ldots$ & - & - & $\cdot$ & - & - & - & - & - & - & - \\
\hline Donald C. Cook $2 \ldots \ldots$ & - & - & - & - & - & - & - & - & - & - \\
\hline Cooper Station $\ldots \ldots \ldots$ & . & - & - & - & - & - & - & - & . & . \\
\hline Crystal River $3 \ldots \ldots \ldots$ & - & - & - & - & - & - & - & - & - & - \\
\hline Davis-Besse 1. & - & - & - & - & - & - & - & - & - & - \\
\hline Diablo Canyon $1 \ldots \ldots \ldots$ & . & - & - & . & - & - & - & - & . & - \\
\hline Diablo Canyon $2 \ldots . .$. & - & - & - & - & - & - & - & - & - & - \\
\hline Dresden $2 \ldots \ldots \ldots \ldots$ & - & - & - & - & - & - & - & . & - & . \\
\hline Dresden $3 \ldots \ldots \ldots$ & - & - & - & - & - & - & - & - & - & - \\
\hline Duane Arnold. & - & - & - & & - & - & - & - & . & - \\
\hline Enrico Fermi 2 & - & - & - & - & - & . & - & - & . & - \\
\hline Joseph M. Farley $1 \ldots \ldots$ & - & . & . & - & - & - & - & . & . & . \\
\hline Joseph M. Farley $2 \ldots \ldots$ & - & - & - & - & - & - & - & - & - & - \\
\hline James Fitzpatrick $\ldots \ldots \ldots$ & - & - & - & - & - & - & - & . & - & - \\
\hline Fort Calhoun $\ldots \ldots \ldots \ldots$ & . & . & . & - & - & . & - & - & - & . \\
\hline Ginna $\ldots \ldots \ldots \ldots \ldots$ & - & - & - & - & - & - & - & - & - & - \\
\hline Grand Gulf $1 \ldots \ldots \ldots$ & - & - & - & - & - & - & - & - & - & - \\
\hline Haddam Neck . . . . . . . . . . & - & - & - & - & - & . & - & . & . & . \\
\hline Shearon Harris $1 \ldots \ldots$. . . & - & - & - & - & - & - & - & . & - & - \\
\hline Edwin I. Hatch $1 \ldots \ldots \ldots$ & - & - & - & - & - & - & - & . & . & . \\
\hline Edwin I. Hatch $2 \ldots \ldots \ldots$ & - & - & - & - & - & . & . & - & . & - \\
\hline Hope Creek . . . . . . . . . . & - & - & - & - & - & - & - & - & . & - \\
\hline Indian Point $2 \ldots \ldots \ldots$ & - & - & - & . & - & - & - & - & . & . \\
\hline Indian Point $3 \ldots \ldots \ldots$ & - & - & - & - & - & - & - & - & . & - \\
\hline Kewaunee $\ldots \ldots \ldots \ldots$ & - & . & - & - & - & - & . & - & - & - \\
\hline LaSalle City $1 \ldots \ldots \ldots$ & - & - & - & - & - & . & - & . & . & . \\
\hline LaSalle City $2 \ldots \ldots \ldots$ & - & - & - & - & - & - & - &. & - & . \\
\hline Limerick $1 \ldots \ldots$ & - & - & - & - & - & - & - & . & - & - \\
\hline Limerick $2 \ldots \ldots \ldots$ & - & - & - & - & - & - & - & - & - & - \\
\hline Maine Yankee ........... & - & - & - & - & - & - & - & - & - & - \\
\hline McGuire $1 \ldots \ldots$ & - & - & - & - & - & - & - & - & - & - \\
\hline McGuire $2 \ldots \ldots \ldots \ldots$ & - & - & $\cdot$ & - & $\cdot$ & - & - & - & - & 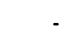 \\
\hline Millstone $1 \ldots \ldots \ldots$ & - & . & - & - & - & - & - & - & - & - \\
\hline Millstone $2 \ldots \ldots \ldots$ & - & - & - & . & - & - & . & - & . & . \\
\hline Millstone $3 \ldots \ldots \ldots$ & . & - & - & - & - & - & . & - & . & - \\
\hline Monticello . . . . . . . . . . . . & - & - & & - & - & - & - & & - & . \\
\hline
\end{tabular}

See footnote at end of table. 
Table D9. Projected Spent Fuel Discharges by U.S. Reactors in the No New Orders Case, 2031-2040 (Continued)

(Metric Tons of Initial Heavy Metal)

\begin{tabular}{|c|c|c|c|c|c|c|c|c|c|c|}
\hline Unit & 2031 & 2032 & 2033 & 2034 & 2035 & 2036 & 2037 & 2038 & 2039 & 2040 \\
\hline Nine Mille Point $1 \ldots \ldots \ldots$ & . & - & - & - & : & - & - & - & - & - \\
\hline Nine Mile Point $2 \ldots \ldots \ldots$ & - & - & - & - & - & - & . & - & . & - \\
\hline North Anna $1 \ldots \ldots \ldots$ & - & - & - & - & - & - & - & - & - & - \\
\hline North Anna $2 \ldots \ldots \ldots$ & - & - & - & - & - & - & - & - & - & - \\
\hline Ocones $1 \ldots \ldots \ldots \ldots$ & - & - & - & - & - & - & - & - & - & \\
\hline Oconee $2 \ldots \ldots \ldots \ldots$ & - & - & - & - & - & - & - & - & - & - \\
\hline Oconee $3 \ldots \ldots \ldots$ & - & - & - & - & - & - & . & - & - & - \\
\hline Oyster Creek $1 \ldots \ldots \ldots$ & . & - & - & - & - & - & . & . & . & - \\
\hline Palisades $\ldots \ldots \ldots \ldots$ & - & . & . & - & - & - & - & - & . & . \\
\hline Palo Verde $1 \ldots \ldots \ldots$ & - & - & - & - & - & - & - & . & . & 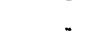 \\
\hline Palo Verde $2 \ldots \ldots$ & - & - & - & . & - & . & . & - & . & - \\
\hline Palo Verde 3 . . . . . . . . & - & - & - & - & - & - & - & - & - & - \\
\hline Peachbottom $2 \ldots \ldots$ & - & - & - & - & - & - & - & - & - & . \\
\hline Peachbottom $3 \ldots \ldots$ & - & - & - & - & . & - & . & . & - & . \\
\hline Perry $1 \ldots \ldots \ldots \ldots$ & - & - & - & - & . & - & . & . & 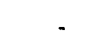 & - \\
\hline Pilgrim $1 \ldots \ldots$ & - & - & - & - & - & - & - & . & - & - \\
\hline Point Beach $1 \ldots \ldots \ldots$ & - & - & - & . & . & - & - & - & . & - \\
\hline Point Beach $2 \ldots \ldots \ldots$ & - & - & - & - & . & - & - & - & - & - \\
\hline Prairie Island $1 \ldots \ldots \ldots$. & - & - & - & - & - & - & - & - & - & - \\
\hline Prairie Island $2 \ldots \ldots \ldots$ & - & - & - & - & - & - & - & - & - & - \\
\hline Quad Citles $1 \ldots \ldots \ldots$ & - & - & - & - & - & - & - & - & . & 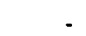 \\
\hline Quad Cities $2 \ldots \ldots \ldots$ & - & - & - & - & - & - & - & - & - & - \\
\hline H.B. Robinson $2 \ldots \ldots \ldots$ & - & - & - & - & - & - & . & . & 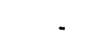 & - \\
\hline River Bend $1 \ldots \ldots \ldots$ & - & - & - & - & . & - & - & . & - & - \\
\hline Salem $1 \ldots \ldots \ldots \ldots$ & - & - & - & - & - & - & - & - & - & - \\
\hline Salem $2 \ldots \ldots \ldots$ & - & - & - & - & - & - & - & - & - & - \\
\hline San Onofre $1 \ldots \ldots \ldots$ & - & - & . & - & - & - & - & . & - & . \\
\hline San Onofre $2 \ldots \ldots \ldots$ & - & - & . & - & . & . & . & . & . & : \\
\hline San Onofre $3 \ldots \ldots \ldots$ & - & - & - & - & - & . & . & . & - & . \\
\hline Seabrook $1 \ldots \ldots \ldots$ & - & - & - & - & - & - & - & - & - & . \\
\hline Sequoyah 1 . . . . . . & - & - & - & - & & - & - & - & - & - \\
\hline Sequoyah $2 \ldots \ldots \ldots$ & - & - & - & - & - & - & . & . & - & - \\
\hline South Texas $1 \ldots \ldots \ldots$ & - & . & - & - & . & - & . & . & - & . \\
\hline South Texas $2 \ldots \ldots \ldots$ & - & - & - & - & . & - & . & . & . & : \\
\hline St. Lucie $1 \ldots \ldots$ & - & - & - & - & - & - & - & - & . & - \\
\hline St. Lucie $2 \ldots \ldots$ & - & - & - & - & - & - & - & . & - & . \\
\hline Summer $1 \ldots \ldots \ldots$ & - & - & - & - & - & - & - & - & & - \\
\hline Surry $1 \ldots \ldots \ldots \ldots$ & - & - & - & 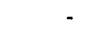 & - & - & - & - & - & - \\
\hline Surry $2 \ldots \ldots \ldots \ldots$ & - & - & - & - & - & - & - & - & - & . \\
\hline Susquehanna $1 \ldots \ldots \ldots$ & - & - & - & - & . & . & . & - & - & . \\
\hline Susquehanria $2 \ldots \ldots \ldots$ & - & - & - & - & . & . & 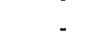 & 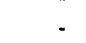 & . & : \\
\hline Three Mile Island $1 \ldots \ldots$ & - & 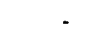 & - & - & . & - & - & - & - & - \\
\hline Trojan ............. & - & - & - & - & - & - & - & . & - & . \\
\hline Turkey Point $3 \ldots \ldots$ & - & - & - & - & - & - & 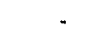 & - & - & - \\
\hline Turkey Point $4 \ldots \ldots \ldots$ & - & - & - & - & - & - & - & . & - & - \\
\hline Vogtle $1 \ldots \ldots \ldots \ldots$ & - & - & - & - & - & - & - & - & . & . \\
\hline$\ldots \ldots$ & - & - & . & - & . & . & 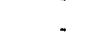 & . & . & : \\
\hline Vermont Yankee $1 \ldots \ldots$ & - & - & - & - & . & - & - & . & . & . \\
\hline Washington Nuclear $2 \ldots \ldots$ & - & - & - & . & - & - & - & - & - & . \\
\hline Waterford $3 \ldots \ldots \ldots$ & & & - & - & 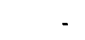 & - & - & . & . & . \\
\hline Watts $\operatorname{Bar} 1 \ldots \ldots \ldots$ & 28 & 89 & - & & & - & - & - & - & . \\
\hline Watts Bar $2 \ldots \ldots \ldots$ & 28 & 25 & - & 27 & 89 & . & . & - & - & . \\
\hline Wolf Creek $1 \ldots \ldots$ & & & & & & - & - & - & - & - \\
\hline Yankee-Rowe $1 \ldots \ldots \ldots$ & - & - & - & - & - & - & - & . & . & . \\
\hline Zion $1 \ldots \ldots \ldots \ldots$ & - & - & - & - & - & - & - & . & - & - \\
\hline Zion $2 \ldots \ldots \ldots \ldots$ & - & - & - & - & . & - & . & - & - & . \\
\hline BWR Subtotal. & & & & & & & & & 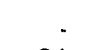 & - \\
\hline PWA Subtotal . . . . . . & 147 & 192 & 70 & 27 & 155 & 31 & 31 & 63 & 24 & 220 \\
\hline Total ............. & 147 & 192 & 70 & 27 & 155 & 31 & 31 & 63 & 24 & 220 \\
\hline
\end{tabular}

Source: Projections derived from the International Nuclear Model and Form RW-859, "Nuclear Fuel Data" (1989). 
Appendix E

Data Sources

$21 / 22$ 


\section{Appendix E \\ Data Sources}

Figures 1, 2, 3, 4, 5

Projected uranium requirements calculated using the International Nuclear Model, based on capacity projections from Energy Information Administration, Commercial Nuclear Power 1990: Prospects for the United State's and the World, DOE/EIA-(1438(90) (Washington, DC, September 1990), Table 8.

\section{Figures 6, 7}

Actual Data: Energy Information Administration, Form RW-859, "Nuclear Fuel Data" (1989). Projections: International Nuclear Model and Form RW-859, "Nuclear Fuel Data" (1989).
Figures 8, 9, 10, 11, 12, 13

Projected uranium requirements calculated using the International Nuclear Model, based on capacity projections from Energy Information Administration, Commercial Nuclear Power 1990: Prospects for the Linited States and the World, DOE/EIA-0438(90) (Washington, DC, September 1990), Table 24. 


\section{Glossary}

Boiling-Water Reactor (BWR): A light-water reactor in which water, used as both coolant and moderator, is allowed to boil in the core. The resulting steam can be used directly to drive a turbine.

Breeder Reactor: A reactor that both produces and consumes fissionable fuel, especially one that creates more fuel than it consumes. The new fissionable material is created by a process known as breeding, in which neutrons from fission are captured in fertile materials.

Burnup: A measure of the amount of energy obtained from fuel in a reactor. Typically, burnup is expressed as the amount of energy produced per unit weight of fuel irradiated or "burned." Burnup levels are generally measured in units of megawattdays thermal per metric ton of initial heavy metal (MWDT/MTIHM).

Canadian Deuterium-Uranium Reactor (CANDU): Uses heavy water or ieuterium oxide $\left(D_{2} \mathrm{O}\right)$, rather than light water $\left(\mathrm{H}_{2} \mathrm{O}\right)$ as the coolant and moderator. Deuterium is an isotope of hydrogen that has a different neutron absorption spectrum from that of ordinary hydrogen. In a deuterium-oxide-moderated reactor, fuel made from natural uranium (0.71 U-235) can sustain a chain reaction.

Capacity: The load for which a generating unit is rated, either by the user or by the manufacturer. In this report, "capacity" refers to the utility's design electrical rating (see below).

Capacity Factor: The ratio of the electricity produced by a generating unit, for the period of time considered, to the energy that could have been produced at continuous full-power operation during the same period.

Commercial Operation: The phase of reactor operation that begins when power ascension ends and the operating utility formally declares the nuclear power plant to be available for the regular production of electricity. This declaration is usually related to the satisfactory completion of qualification tests on critical components of the unit.

Construction Pipeline: The various stages involved in the acquisition of a nuclear reactor by a utility. The events that define these stages are the ordering of a reactor, the licensing process, and the physical construction of the nuclear generating unit. A reactor is said to be "in the pipeline" when the reactor is ordered and "out of the pipeline" when it completes" low-power testing and begins operation toward full power. (See Operable).

Design Electrical Rating (capacity), Net: The nominal net electrical output of a nuclear unit, as specified by the utility for the purpose of plant design.

Discharged Fuel: Irradiated fuel removed from a reactor during refueling. (See Spent Fuel.)

Enrichment Tails Assay: A measure of the amount of fissile uranium (U-235) remaining in the waste stream from the uranium enrichment process. The natural uranium "feed" that enters the enrichment process generally contains 0.711 percent (by weight) U-235. The "product stream" contains enriched uranium (greater than 0.711 percent $\mathrm{U}-2.35$ ) and the "waste" or "tails" stream contains depleted uranium (less than 0.711 percent $U-235$ ). At the historical enrichment tails assay of 0.2 percent, the waste stream would contain 0.2 percent U-235. A higher enrichment tails assay requires more uranium feed (thus permitting natural uranium stockpiles to be decreased), while increasing the output of enriched material for the same energy expenditure.

Equilibrium Cycle: An analytical term which refers to fuel cycles that occur after the initial one or two cycles of a reactor's operation. For a given reactor, equilibrium cycles have similar fuel characteristics.

Fast Breeder Reactor (FBR): A reactor in which the fission chain reaction is sustained primarily by fast neutrons rather than by thermal or intermediate neutrons. Fast reactors require little or no moderator to slow down the neutrons from the speeds at which they are ejected from fissioning nuclei. This type of reactor produces more fissile material than it consumes.

Fertile Material: Material that is not itself fissionable by thermal neutrons but can be converted to fissile material by irradiation. The two principal fertile materials are uranium-238 and thorium-232.

Fissile Material: Material that can be caused to undergo atomic fission when bombarded by neutrons. 
The most important fissionable materials are uranium-235, plutonium-239, and uranium-233.

Fission: The process whereby an atomic nucleus of appropriate type, after capturing a neutron, splits into (generally) two nuclei of lighter elements, with the release of substantial amounts of energy and two or more neutrons.

FME: Free Market Economies. Countries that are members of the Council for Mutual Economic Assistance (CMEA) are not included.

Forward Costs: The operating and capital costs (in current dollars) still to be incurred in the production of uranium from estimated reserves; such costs are used in assigning the uranium reserves to cost categories. Forward costs include labor, materials, power and fuel, royalties, payroll and production taxes, insurance, and general and administrative costs. Expenditures prior to reserve estimates-e.g, for property acquisition, exploration, mine development, and mill construction-are excluded from forward cost determinations. Income taxes, profit, and the cost of money are also excluded. Thus, forward costs are neither the full costs of production nor the market price at which the uranium will be sold.

Full Power Day: The equivalent of 24 hours of full power operation by a reactor. The number of full power days in a specific cycle is the product of the reactor's capacity factor and the length of the cycle.

Gas-Cooled Fast Breeder Reactor (GCBR): A fast breeder reactor that is cooled by a gas (usually helium) under pressure.

Generation (Electricity): The process of producing electric energy from other forms of energy; also, the amount of electric energy produced, expressed in watthours $(\mathrm{Wh})$.

Gross Generation: The total amount of electric energy produced by the generating units at a generating station or stations, measured at the generator terminals.

Net Generation: Gross generation less the electric energy consumed at the generating station for station use.

Gigawatt-Electric (GWe): One billion watts of electric capacity.

Heavy Water: Water containing a significantly greater proportion of heavy hydrogen (deuterium) atoms to ordinary hydrogen atoms than is found in ordinary (light) water. Heavy water is used as a moderator in some reactors because it slows neutrons effectively and also has a low cross-section for absorption of neutrons.

Heavy-Water-Moderated Reactor: A reactor that uses heavy water as its moderator. Heavy water is an excellent moderator and thus permits the use of inexpensive natural (unenriched) uranium as fuel.

Kilowatt-Electric (kWe): One thousand watts of clectric capacity.

Kilowatthour (kWh): One thousand watthours.

Light Water: Ordinary water $\left(\mathrm{H}_{2} \mathrm{O}\right)$, as distinguished from heavy water or deuterium oxide $\left(\mathrm{D}_{2} \mathrm{O}\right)$.

Light-Water Reactor (LWR): A nuclear reactor that uses water as the primary coolant and moderator, with slightly enriched uranium as fuel. There are two types of commercial light-water reactor-the boilingwater reactor (BWR) and the pressurized-water reactor (PWR).

Liquid Metal Fast Breeder Reactor (LMFBR): A nuclear breeder reactor, cooled by molten sodium, in which fission is caused by fast neutrons.

Low-Power Testing: The period of time between a plant's initial fuel loading date and the issuance of its operating (full power) license. The maximum level of operation during this period is 5 percent of the unit's design electrical rating.

Megawatt-Electric (MWe): One million watts of electric capacity.

Megawatthour (MWh): One million watthours of electric energy.

Moderator: A material such as ordinary water, heavy water, or graphite, used in a reactor to slow down high-velocity neutrons, thus increasing the likelihood of further fission.

Net Summer Capability: The steady hourly output which generating equipment is expected to supply to system load exclusive of auxiliary power as demonstrated by testing at the time of summer peak demand.

Nuclear Power Plant: A single- or multi-unit facility in which heat produced in a reactor by the fissioning of nuclear fuel is used to drive a steam turbine(s).

Nuclear Reactor: An apparatus in which the nuclear fission chain can be initiated, maintained, and controlled so that energy is released at a specific rate. The reactor apparatus includes fissionable material (fuel) such as uranium or plutonium; fertile material; moderating material (unless it is a fast reactor); a 
heavy-walled pressure vessel; shielding to protect personnel; provision for heat removal; and control elements and instrumentation.

Plutonium (Pu): A heavy, fissionable, radioactive, metallic element (atomic number 94). Plutonium occurs in nature in trace amounts. It can also be produced as a byproduct of the fission reaction in a uranium-fueled nuclear reactor and can be recovered for future use.

Power Ascension: The period of time between a plant's initial fuel loading date and its date of first commercial operation (including the low-power testing period). Plants in the first operating cycle (the time from initial fuel loading to the first refueling), which lasts approximately 2 years, operate at an average capacity factor of about 40 percent.

Pressurized-Water Reactor (PWR): A nuclear reactor in which heat is transferred from the core to a heat exchanger via water kept under high pressure, so that high temperatures can be maintained in the primary system without boiling the water. Steam is generated in a secondary circuit.

Reasonably Assured Resources (RAR): Resource category that refers to tiranium that occurs in known mineral deposits of such size, grade, and configuration that it could be recovered within the given production cost ranges, with currently proven mining and processing technology. Estimates of tonnage and grade are based on specific sample data and measurements of the deposits and on knowledge of deposit characteristics. The RAR category corresponds to the U.S. Department of Energy (DOE) Reserves category.

Reinserted Fuel: Irradiated fuel that is discharged in one cycle and inserted in the same reactor during a subsequent refueling. In a few cases, fuel discharged from one reactor has been used to fuel a different reactor.

Separative Work Unit (SWU): The standard measure of enrichment services. The effort expended in separating a mass $F$ of feed of assay $x_{1}$ into a mass $P$ of product of assay $x_{1}$ and waste of mass $W$ and assay $x_{i v}$ is expressed in terms of the number of separative work units noeded, given by the expression SWU $=W V\left(x_{1,}\right)+P V\left(x_{1}\right)-F V\left(x_{1}\right)$, where $V(x)$ is the "value function," defined as $V(x)=(1-2 x) \ln |(1-x) / x|$.

Spent Fian: Irradiated fuel that is permanently discharger. from a reactor at the end of a fuel cycle. Except for possible reprocessing, this fuel must cventually be removed from its temporary storage location at the reactor site and placed in a permanent repository. Spent fuel is typically measured either in metric tons of heavy metal (i.e., only the heavy metal content of the spent fuel is considered) or in metric tons of initial heavy metal (essentially, the initial mass of the uranium before irradiation). The difference between these two quantities is the weight of the fission products.

Terawatthour (TWh): One trillion (10 (1.2) watthours of electric energy.

Uranium (U): A heavy, naturally radioactive, metallic clement (atomic number 92). Its $t w 0$ principally occurring isotopes are uranium-235 and uranium-238. Uranium-235 is indispensable to the nuclear industry, because it is the only isotope existing in nature, to any appreciable extent, that is fissionable by thermal neutrons. Uranium-238 is also important, because it absorbs neutrons to produce a radioactive isotope that subsequently decays to plutonium-239, an isotope that also is fissionable by thermal neutrons. 

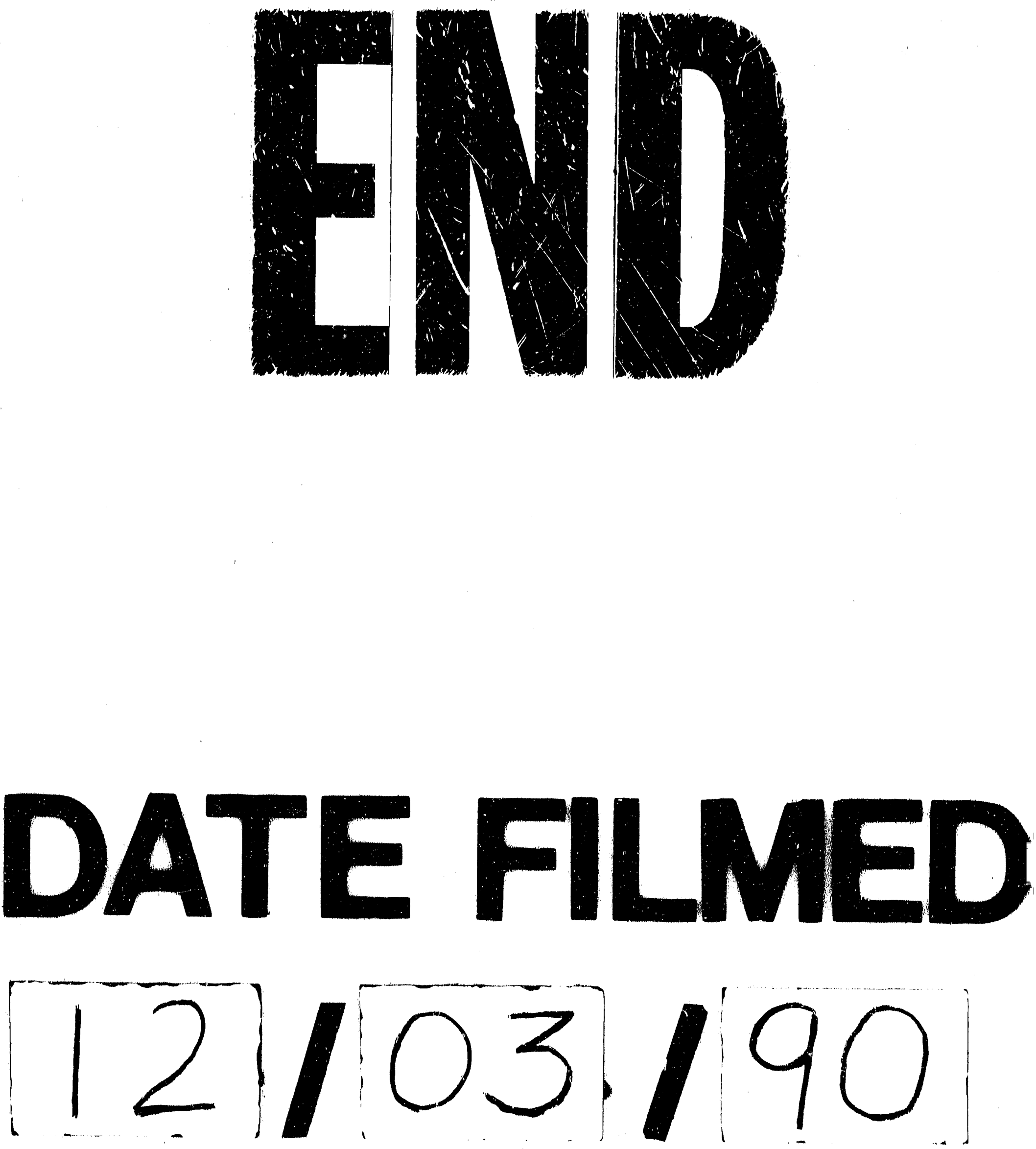
